\title{
Steamboat Hills Exploratory Slimhole: Drilling and Testing
}

John T. Finger, Ronald D. Jacobson, Charles E. Hickox, Roger R. Eaton

\section{Prepared by}

Sandia National Laboratorles

Albuquarque, Now Mexico 87185 and Lifarmoro, Callformia 94550

for the United States Department of Energy

under Contract DE-ACO4-94AL85000

Approved for public release; distribution is unlimited.

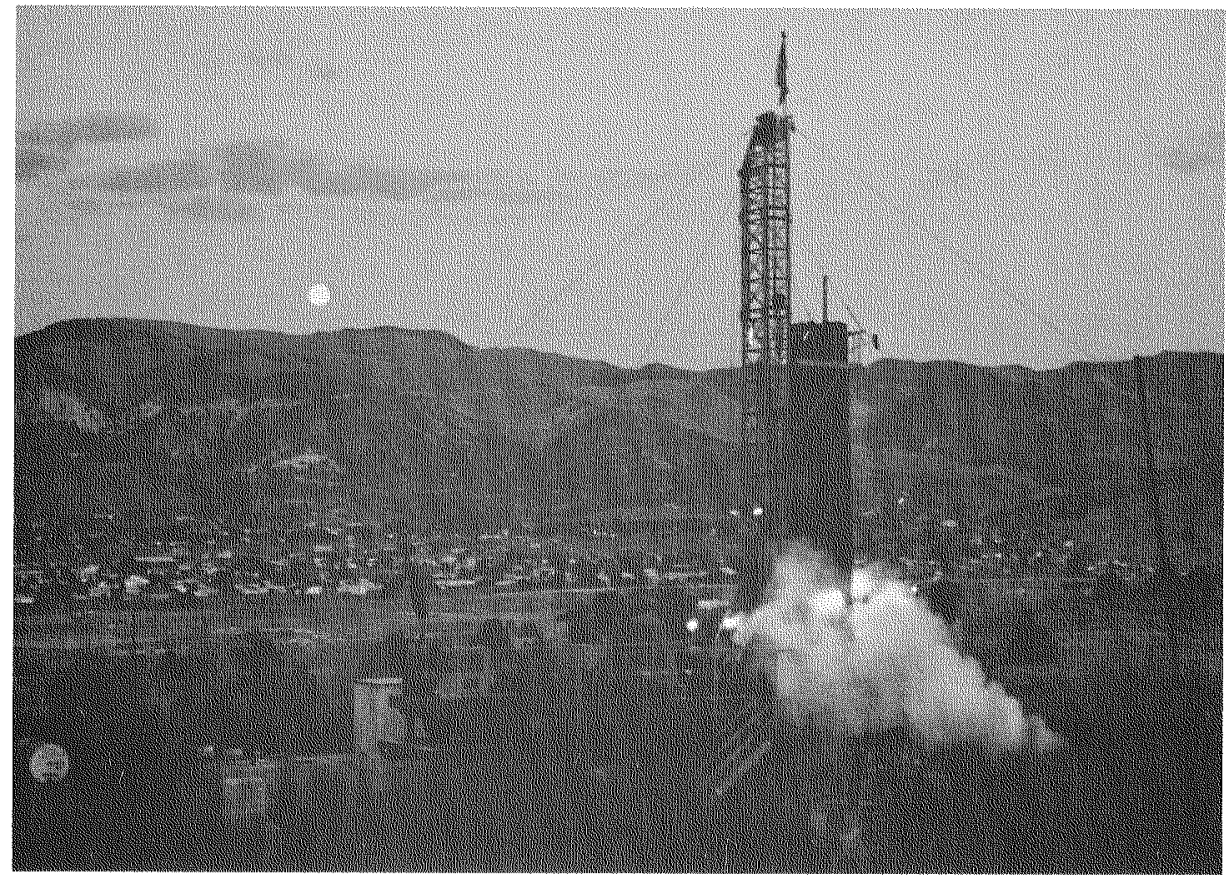




\section{DISCLAIMER}

This report was prepared as an account of work sponsored by an agency of the United States Government. Neither the United States Government nor any agency Thereof, nor any of their employees, makes any warranty, express or implied, or assumes any legal liability or responsibility for the accuracy, completeness, or usefulness of any information, apparatus, product, or process disclosed, or represents that its use would not infringe privately owned rights. Reference herein to any specific commercial product, process, or service by trade name, trademark, manufacturer, or otherwise does not necessarily constitute or imply its endorsement, recommendation, or favoring by the United States Government or any agency thereof. The views and opinions of authors expressed herein do not necessarily state or reflect those of the United States Government or any agency thereof. 


\section{DISCLAIMER}

Portions of this document may be illegible in electronic image products. Images are produced from the best available original document. 
Issued by Sandia National Laboratories, operated for the United States Department of Energy by Sandia Corporation.

NOTICE: This report was prepared as an account of work sponsored by an agency of the United States Government. Neither the United States Government nor any agency thereof, nor any of their employees, nor any of their contractors, subcontractors, or their employees, makes any warranty, express or implied, or assumes any legal liability or responsibility for the accuracy, completeness, or usefulness of any information, apparatus, product, or process disclosed, or represents that its use would not infringe privately owned rights. Reference herein to any specific commercial product, process, or service by trade name, trademark, manufacturer, or otherwise, does not necessarily constitute or imply its endorsement, recommendation, or favoring by the United States Government, any agency thereof or any of their contractors or subcontractors. The views and opinions expressed herein do not necessarily state or reflect those of the United States Government, any agency thereof or any of their contractors.

Printed in the United States of America. This report has been reproduced directly from the best available copy.

Available to DOE and DOE contractors from

Office of Scientific and Technical Information

PO Box 62

Oak Ridge, TN 37831

Prices available from (615) 576-8401, FTS 626-8401

Available to the public from

National Technical Information Service

US Department of Commerce

5285 Port Royal RD

Springfield, VA 22161

NTIS price codes

Printed copy: A05

Microfiche copy: A06 
SAND94-0551

Unlimited release

Printed Oct. 1994

\title{
STEAMBOAT HILLS EXPLORATORY SLIMHOLE: DRILLING AND TESTING
}

\author{
John T. Finger \\ Ronald D. Jacobson \\ Geothermal Research Department \\ Charles E. Hickox \\ Computational Fluid Dynamics Department \\ Roger R. Eaton \\ Thermal and Fluid Engineering Department
}

\begin{abstract}
During July-September, 1993, Sandia National Laboratories, in cooperation with Far West Capital, drilled a 4000' exploratory slimhole (3.9" diameter) in the Steamboat Hills geothermal field near Reno, Nevada. This well was part of Sandia's program to evaluate slimholes as a geothermal exploration tool. During and after drilling we performed four series of production and injection tests while taking downhole (pressure-temperature-spinner) and surface (wellhead pressure and temperature, flow rate) data. In addition to these measurements, the well's data set includes: continuous core (with detailed log); borehole televiewer images of the wellbore's upper 500'; daily drilling reports from Sandia and from drilling contractor personnel; daily drilling fluid record; numerous temperature logs; and comparative data from production and injection wells in the same field.
\end{abstract}

This report contains: (1) a narrative account of the drilling and testing, (2) a description of equipment used, (3) a brief geologic description of the formation drilled, (4) a summary and preliminary interpretation of the data, and (5) recommendations for future work.

This work was supported by the US Department of Energy at Sandia National Laboratories under contract DE-AC04-94AL8500 


\section{TABLE OF CONTENTS}

I. Introduction and Background 3

II. Summary of Operations 4

III. Description of Test Equipment and Methods 5

IV. Preliminary Analysis of Available Data 7

$\begin{array}{ll}\text { V. Discussion } & 12\end{array}$

$\begin{array}{ll}\text { VI. Conclusions } & 13\end{array}$

$\begin{array}{ll}\text { VII. Recommendations } & 14\end{array}$

$\begin{array}{ll}\text { VIII. Brief Geologic Description } & 15\end{array}$

$\begin{array}{ll}\text { IX. Glossary } & 16\end{array}$

$\begin{array}{lll}\text { X. } & \text { References } & 17\end{array}$

Appendix A - Detailed Narrative of Operations

Appendix B - Daily Drilling Reports 


\section{INTRODUCTION AND BACKGROUND}

The Geothermal Research Department at Sandia National Laboratories is working with industry to evaluate slimhole drilling as a geothermal exploration technique. Traditionally, diamond-cored "slimholes" -- usually 3" to 4" in diameter -- have been used to measure temperature gradients while selecting sites for production-size exploration wells. If we can demonstrate that improved testing in slimholes reliably identifies a productive geothermal resource, the cost savings and reduced environmental impact, compared to production-size holes, are compelling incentives to use slimholes for exploration. 1

Sandia first established the basic feasibility of slimhole exploration with in-house analysis and field experiments on existing geothermal coreholes and then conducted an extensive survey of the geothermal industry to define its needs and priorities. Industry contacts specified lower-cost exploration as a high priority, and were generally enthusiastic over the slimhole idea. Further negotiations with Far West Capital, which operates the Steamboat Hills geothermal field, resulted in an agreement to drill and test an exploratory well on their lease. This exploratory well (number SNLG 87-29) was specifically designed for extensive production and injection tests so that those results could be compared with production and injection data from existing wells in this developed field. In fact, the exploratory well is drilled approximately 30 feet from an existing, but unused, production well. This report describes our drilling and testing activities, and gives a preliminary summary and interpretation of the data, as well as recommendations for future projects.

Steamboat Hills geothermal area is located about eight miles south of Reno, Nevada, and currently supports two power plants with a rated total output of approximately $36 \mathrm{MWe}$. Production zones for the power-plant wells are typically shallow (less than 1000'), of moderate temperature $\left(\sim 325^{\circ} \mathrm{F}\right)$, characterized by large, well-connected fractures in granodiorite (see Section VIII for more detail on the formation), and extremely permeable; test data ${ }^{2}$ indicate values of transmissivity exceeding 1,000 Da-ft. Wells previously drilled here showed temperature reversals, with the maximum temperature above $1000^{\prime}$ (see Figure 1 for temperature log from the exploratory slimhole), however, a nearby power plant on another operator's lease draws from a reservoir at approximately $420^{\circ} \mathrm{F}$, indicating that a hotter resource might lie beneath the one currently produced for the Far West power plants. Extensive previous development in this field meant that drilling conditions were reasonably well-known, but because most of the existing wells are shallow, there was still an opportunity for slimhole exploration in search of

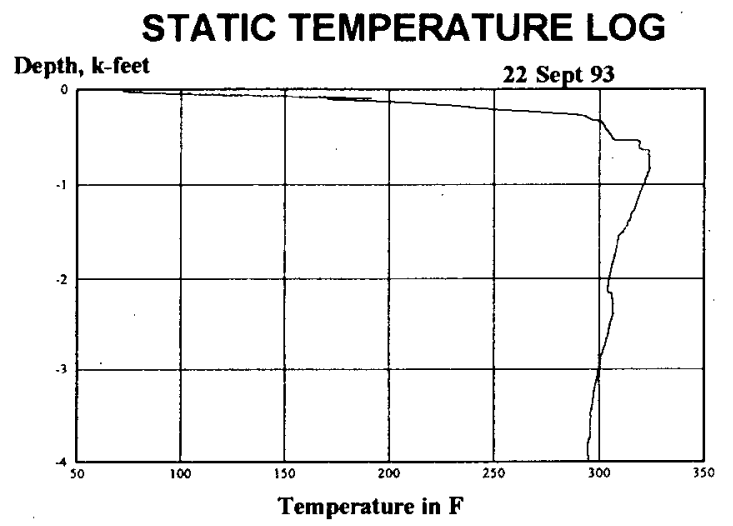

Figure 1 a deeper, hotter reservoir.

The principal objectives for this test program were the following: development of slimhole testing methods, comparison of slimhole data with that from adjacent production-size wells, and definition of formation-temperature profiles below the existing wells. Although not all of these objectives were completely met, the exploratory well (which ended at a total depth (TD) of 4001') was generally successful in gathering a large amount of data useful to the slimhole development program and to the operator. 


\section{SUMMARY OF OPERATIONS}

To meet our testing and data collection goals, this well was designed to meet the following criteria:

- Recover continuous core from surface to TD.

- Obtain a competent cement job on all casing, to allow extended production testing.

- Maintain HQ hole diameter (3.89") as deep as possible, to allow setting packers for isolation of possible production/injection zones.

The well design (Figure 2) has $7 "$ casing to nominal 150 ' and 4-1/2" casing to nominal 500 feet. Since regulatory agencies require WELL DESIGN: SNLG 87-29 at least $10 \%$ of the total depth to be cased, this casing program allows a maximum well depth of 5000', even though the drilling permit was for 4000 feet. To minimize the amount of reaming necessary, while still collecting continuous core, the drilling program was to (1) core the first $150^{\prime}$ with $\mathrm{HQ}$, (2) ream to 8-1/2" with roller bit, (3) set 7" casing, (4) drill out of 7" casing with BSF ${ }^{\mathrm{TM}}$ core bit (6-1/4" hole by 4 " core) to $500^{\prime}$, (5) set 4-1/2" flush joint casing, and (6) drill to TD with HQ core tools. This plan was followed to a total depth of 4001 feet. Total

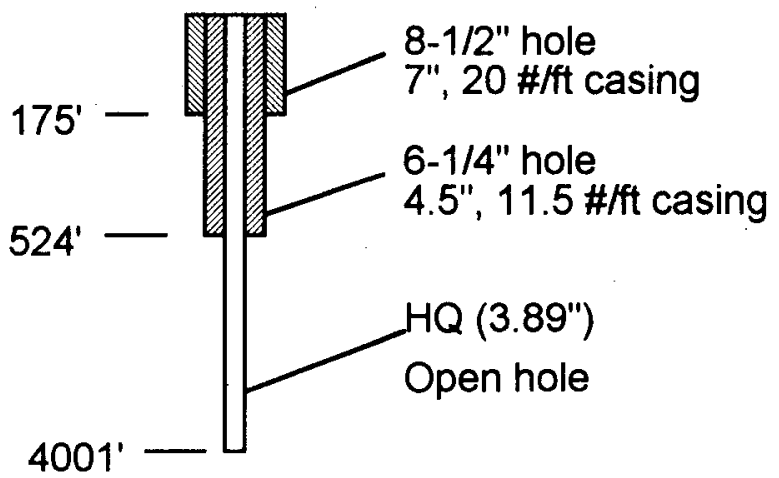
project time, from spud through completion of testing, was 58 days.

During the project we suspended drilling four times for a series of production/injection tests, each time taking downhole (pressure, temperature, spinner) and surface (wellhead pressure and temperature, James tube lip pressure, flow rate) data. These test series were done at well depths of $968,1510,2930$, and 4000 feet. All production tests were initiated by air-lifting the fluid from a depth of approximately $250^{\prime}$, at an air flow rate of approximately $150 \mathrm{scm}$. In general, the surface data, including a comparison of different flow rate measurement techniques, were consistent and repeatable. Downhole data were more difficult to compare because of some malfunctions in the logging tools and because the two service companies which took measurements used different tools and different calibrations. By comparing the downhole readings with the corresponding surface data, however, and by comparing the service companies' tools with Sandia temperature logs, it appears that most of the ambiguities in the downhole data are resolved. The data and conclusions are discussed in Sections IV and V. 


\section{DESCRIPTION OF TEST EQUIPMENT AND METHODS}

The following descriptions cover the major pieces of equipment used during the project and, where applicable, explanations of their use.

Drill rig: The drill rig used for this hole was a Longyear truck-mounted Model HD602, with a 60 mast, capable of pulling $40^{\prime}$ stands of pipe, and a hoist rated at 60,000 pounds. The rig was supported on a hydraulic jack-up substructure which provided approximately 8 ' clearance between the bottom of the substructure and ground level. Two mud pumps were available; a GardnerDenver duplex (150 gpm @ 260 psi) for surface drilling and reaming, and an FMC Model M12 triplex (100 gpm @ 1000 psi) for coring. A 40' parts trailer contained tools, bits, spare parts, and a welder.

Although the granodiorite which comprised more than 3500' of the drilled interval is hard (most of it about 6 on the Mohs hardness scale), bit life averaged over 200' after settling on a Series 7, impregnated diamond bit specifically designed for this formation. Core recovery was very good, more than $99 \%$ for the entire well. Because we completely lost returns after drilling through a major void at $815^{\prime}$, the upper part of the drillstring ran mostly dry, causing intermittent drillstring vibrations. This problem was mitigated by liberal applications of powdered Teflon and bio-degradable rod grease to the core rods as they were tripped into the hole.

This particular rig has a depth capability of approximately $8200^{\prime}$ with the HQ rods used for this project, but heavier duty rigs can be equipped with CHD101 drill rods (approximately 4" diameter) to reach below 10,000' and CHD76 rods (approximately 3 " diameter) to 14,000', enabling slimhole exploration to be used in most known geothermal areas.

Wellhead: The wellhead was designed to not only provide conventional pressure control while drilling, but to allow production testing from the well with minimum changes. The wellhead assembly comprised, from the bottom up, a double-gate BOP, a flow tee, a 4" gate valve, and an annular BOP. The inside diameter of the flow tee was large enough to pass all the HQ tools, allowing the tee to remain in DIAGRAM OF JAMES TUBE DESIGN place during normal drilling so that there was no need to reconfigure the wellhead for testing. The side leg of the flow tee fed, through another 4" valve, into a run of 4 " pipe with a James tube (see Figure 3 for diagram of James tube) mounted at the end, and this exhausted into a flash tank. Given the downhole temperature and

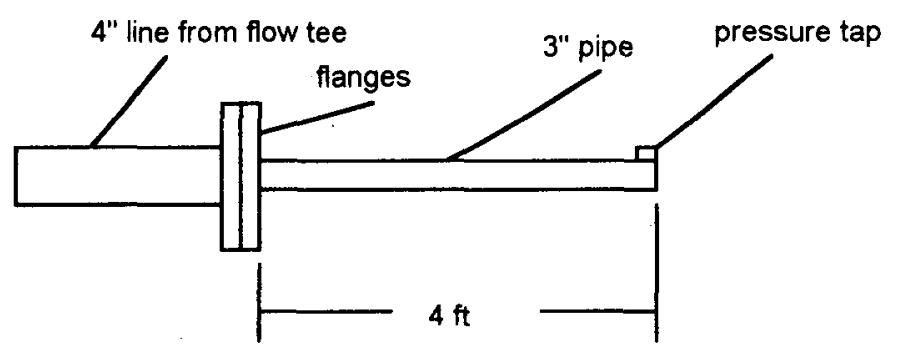

Figure 3

pressure, or enthalpy, the lip pressure measurements from the James tube can be used to calculate the total flow rate from the well. ${ }^{3}$

Flash tank/weir Box: The flash tank was an open-topped 6' diameter by 7 ' high steel tank, equipped with internal baffles, which received the flow from the well through a tangentiallydirected opening in its side. The liquid portion of the flow then passed from the flash tank into a $3^{\prime \prime}$ line, through a magnetic flow meter, and into a $5^{\prime} \times 3^{\prime} \times 3^{\prime}$ weir box. The weir box has a V-shaped notch in an internal partition, and the height of water flowing through this notch is a measure of the liquid flow rate. The liquid flow rate measured in the weir box was consistent with that indicated by the magnetic flow meter.

Surface instrumentation: Instrumentation at and near the wellhead comprised the following: 
- Electronic pressure transducer (0-20 psi) for James tube lip pressure

- Pressure gauge (various) for James tube lip pressure (note: both James tube pressure measurements included approximately 1.2 psi from a water column above the transducer tee -- this water column prevented sub-atmospheric pressures at the transducers and damped pressure fluctuations.)

- Electronic pressure transducer (first 0-200, later 0-60 psi) in the wellhead flow tee

- Pressure gauge (0-100 psi) in the wellhead flow tee

- Electronic pressure transducer (0-200 psi) at the pump/drill rod connection (injection tests)

- Thermal well with thermocouple just downstream of the flow tee 4" valve

- Thermal wells with thermocouples in 3" line between flash tank and weir box and in injection line

- Magnetic flow meter in the 3" line between the flash tank and weir box

- Vortex flow meter in the water line from power plant (measure flow rates for injection) All electrical transducers were connected to a signal-processing station at the drill rig and then, via a simple twisted-pair wire to the data-logging computer in the Sandia trailer. After each test was complete, data from the computer was down-loaded onto diskettes and distributed to other researchers.

Downhole instrumentation: Downhole data during production and injection tests were acquired using pressure/temperature/spinner (PTS) tools from two different service companies. Although details differed, all the commercial downhole instruments were designed to take data and to transmit that data uphole in real time. Since both companies use a single-conductor wireline, the individual signals must be multiplexed up the wire, requiring downhole electronics inside the tools. All the instruments (each company used more than one) employed a dewar, or thermal flask, to protect the electronics, but in spite of that, the internal tool temperature would rise significantly during the course of a normal test. If this effect is not compensated, heating the electronics will cause the signal output to drift, giving unreliable data. A properly calibrated tool accounts for the heating and provides accurately compensated data, but we were not always confident that this was the case with the instrumentation used in this project. This experience indicates to us that there is significant room for improvement in slimhole, high-temperature logging tools.

Numerous temperature logs were taken with Sandia's platinum-resistance-thermometer (PRT) tool which, along with a Sandia logging truck, remained on-site for the entire project. This instrument uses a simple resistance bridge, with changes in resistance measured from the surface through a four-conductor cable. Since there are no downhole electronics, temperature drift with time is negligible and the PRT temperature measurements were considered the reference standard for these tests. Static temperature logs (no flow in hole) were done with this tool before each series of production/injection tests.

Two other Sandia instruments were used briefly: the acoustic borehole televiewer (BHTV) yielded wellbore images down to 520'; and a Sandia memory tool gave pressure-temperature data for a shut-in test at the end of the project. Because no oriented core has been collected in this field, the televiewer images giving fracture direction were extremely informative, but the BHTV could not be used at greater depths because of its temperature limitations $\left(\sim 250^{\circ} \mathrm{F}\right)$. The memory tool, which does not use an electric wireline but stores data downhole in an on-board computer, is still in development and was not ready for use until the very end of the project. It may, however, play a prominent role in future slimhole projects.

Packers: Part of our injection testing used downhole packers for isolating various zones and evaluating their permeability. By running the packers into the hole on N-rod ( 2.75" OD), we had an annulus with roughly the same cross-sectional area as inside of the pipe. This meant that we could inject into either the zone above the packer or the one below, and compare the injectivity of those intervals. 
The packers were manufactured by TAM International and were inflated by pumping into the drill pipe with a wire-line-retrievable standing valve seated in the packer. Once proper inflation pressure was reached, the pump pressure was bled (a check valve holding pressure in the packer) and the standing valve retrieved with the drill rig's wireline. This standing valve arrangement left a large enough ID in the packer for the PTS logging tools to pass through, so we were able to take measurements below the packers while injecting.

\section{PRELIMINARY ANALYSIS OF AVAILABLE DATA}

The results discussed below are based on data from the first series of tests, conducted during August 5-6, 1993, at a total well depth of 968 feet. A large fracture system identified at $815^{\prime}$ was verified by spinner measurements to be the primary production zone for this series of tests and was later observed to be the major feed zone for the 4001 ' completed well. Hence, the flow and injection tests conducted during this first series are representative of the performance observed in subsequent tests when the well was deeper.

Flow testing: In Figures 4, 5, and 6 the temperature, pressure, and spinner response are plotted versus depth. These measurements were made at a total (liquid plus vapor) production rate of 7.1 $\mathrm{kg} / \mathrm{s}(56,350 \mathrm{lb} / \mathrm{hr})$. The liquid water flow rate through the magnetic flow meter and weir box was $6.1 \mathrm{~kg} / \mathrm{s}$ at $192^{\circ} \mathrm{F}(100 \mathrm{gpm}, 48,425 \mathrm{lb} / \mathrm{hr})$. Numerical flow simulations are included in Figures 4 and 5 for comparison and are discussed later. The spinner response, which clearly shows a feed zone at $815^{\prime}$, is proportional to the rotational speed of the impeller, but it was not calibrated as a quantitative measure of relative flow velocity. Based on in situ measurements, we have deduced a relation between spinner output and flow velocity which is consistent with observations in the flowing well.

A secondary objective of flow testing was evaluation of the James tube for slimhole application. The advantage of this method is that only simple equipment is needed to measure the total flow rate and heat rate of the well. Calculations using the James tube flow area, the water flow rate (measured with a weir box), and the lip pressure in the James tube (see Figure 3) will yield total mass flow rate and flow enthalpy, thus simplifying the necessary measurements for those performance criteria. Although there was considerable scatter in the James tube pressure data for these tests, flow rate calculations were in agreement with the measured flow rates.

Wellhead pressures, measured during production for all test series, are plotted versus total mass flow rate in Figure 7. Mass flow rate and total enthalpy were calculated from measurements made with James tubes of various diameters, according to the procedure described by Grant, et al. ${ }^{3}$ For those cases when we could not attain critical flow in the James tube, total fluid enthalpy was estimated from downhole temperature measurements. Knowing total enthalpy, the steam-flash fraction could then be calculated from the enthalpy of the flashed water in the weir box and the latent heat of vaporization at the local atmospheric pressure, total mass flow rate following from this. Unsteadiness of the two-phase flow in the James tube and flash tank created significant scatter in the measurements of James tube lip pressure, flow rate, and wellhead pressure. Nevertheless, the data in Figure 7 are typical of two-phase flow from a liquid-dominated geothermal well. For example, a weak wellhead-pressure maximum apparent in the data at a mass flow rate of approximately 1 to $4.5 \mathrm{~kg} / \mathrm{s}$ is reflected in the superposed curves obtained from numerical simulations of flow in the well.

Reservoir transmissivity: The fracture system at $815^{\prime}$ has such large apparent permeability that only very small pressure increases were observed when relatively large volumes of water were injected. Difficulties with downhole instrumentation and with the injection equipment precluded an accurate estimate of reservoir transmissivity based on these injection tests, but we can estimate 


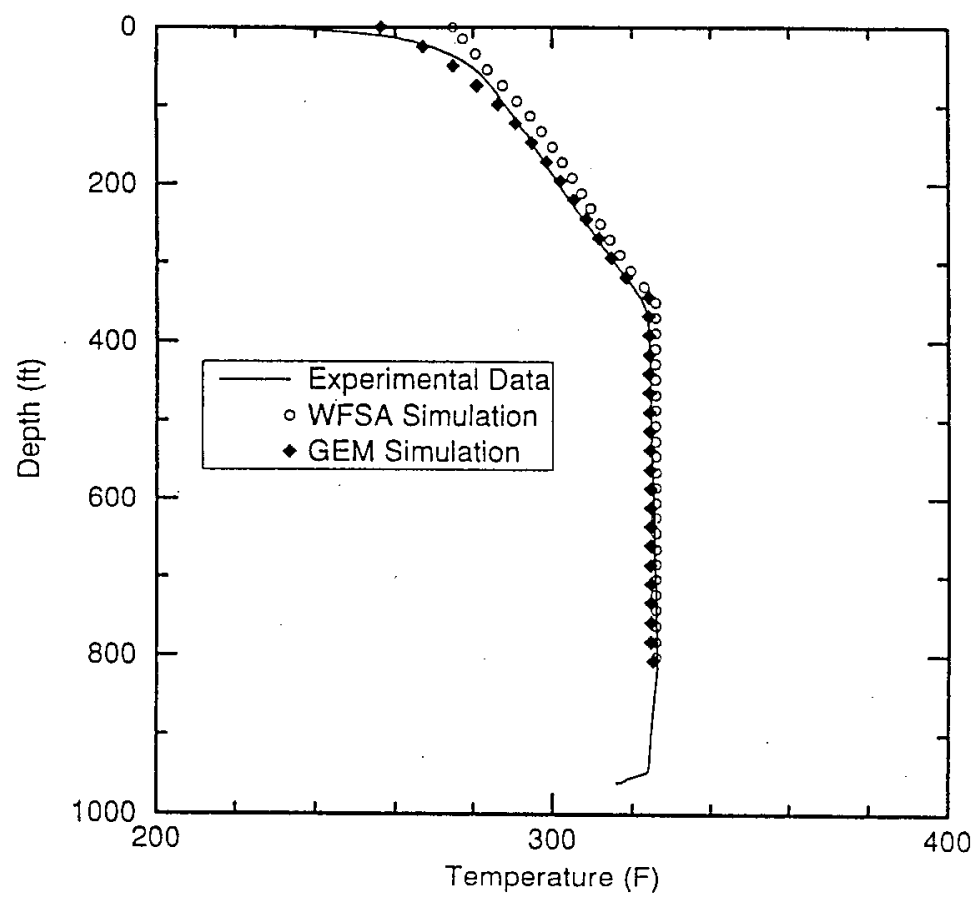

Figure 4. Downhole temperature versus depth; field data and numerical simulation.

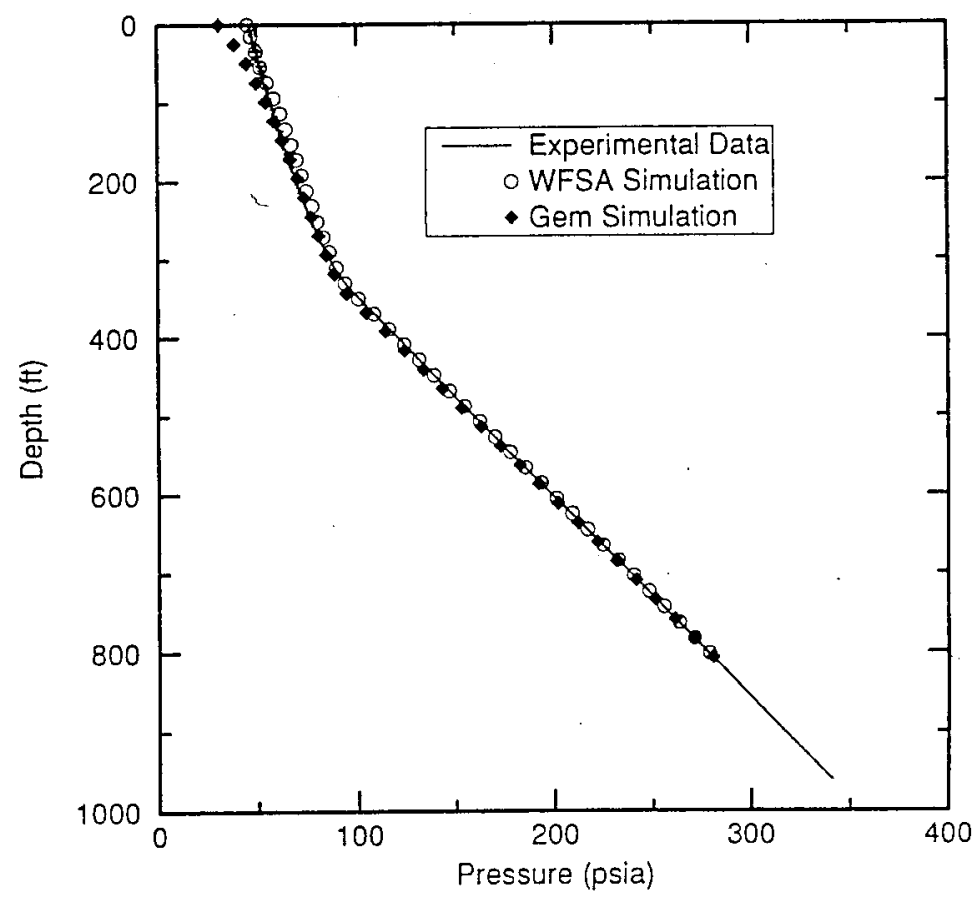

Figure 5." Downhole pressure versus depth; field data and numerical simulation. 


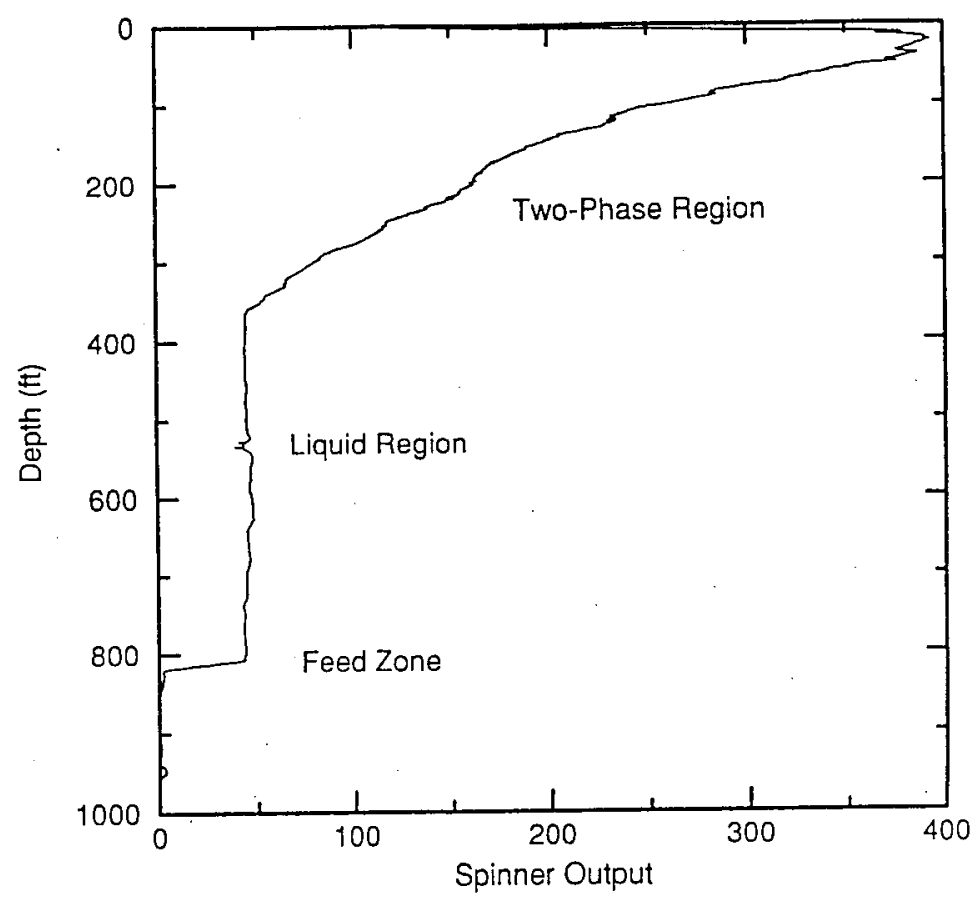

Figure 6. Spinner response versus depth while flowing $56,000 \mathrm{lb} / \mathrm{hr}$.

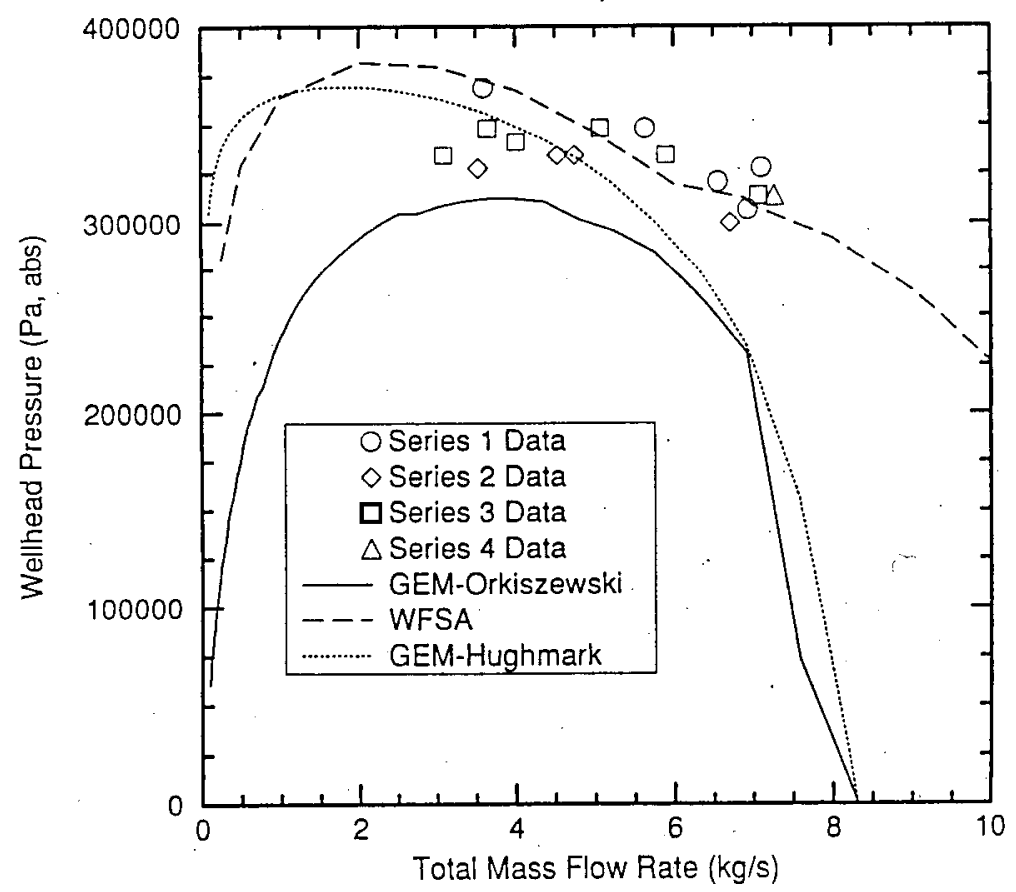

Figure 7. Wellhead pressure versus mass flow rate; field data and numerical simulation. 
some reservoir properties by considering the downhole pressure response during flow rate changes in production tests. ${ }^{4}$ During the first series of flow tests, very small, abrupt, changes in downhole pressure were observed when the flow rate was varied in relatively small increments. For flow rate changes between 6 and $16 \mathrm{gpm}$, pressure changes ranged from 0.05 to $0.07 \mathrm{psi}$. If we assume steady-state conditions, the apparent effective transmissivity, or permeability-depth product, $k h$, can be estimated from the Dupuit, or Theim, formula ${ }^{5}$

$$
\Delta p=\frac{\mu \Delta Q}{2 \pi k h} \ln \frac{r_{o}}{r_{w}},
$$

where $\Delta p$ is the pressure change, $\mu$ is the fluid viscosity, $\Delta Q$ is the change in volumetric flow rate, $r_{w}$ is the well radius, and $r_{o}$ is the outer radius of the reservoir. An arbitrary value of $100 \mathrm{~m}$ is selected for the outer radius, recognizing that the logarithmic term makes the Dupuit formula relatively insensitive to this parameter. Using the fluid viscosity evaluated at downhole conditions, the transmissivity is then estimated to lie in the range 160-600 Da-m, with an average value of approximately $400 \mathrm{Da}-\mathrm{m}$. This estimated average value of transmissivity indicates a pressure increase of only $0.5 \mathrm{psi}$ for an increment of $100 \mathrm{gpm}$ in the injection rate of liquid water.

A shut-in test was also performed immediately following a $100 \mathrm{gpm}$ production test, and this produced a pressure change of $0.2 \mathrm{psi}$. Based on the Dupuit formula, this latter pressure rise indicates a transmissivity in the range of $900 \mathrm{Da}-\mathrm{m}$. Conventional practice for a shut-in test after production, assuming that a significant pressure rise can be observed over an extended period, is to use the Theis equation ${ }^{6}$ for analysis of this transient flow. For a sufficiently large time following shut-in, the Theis equation can be expressed as,

$$
\Delta p=\left(\frac{2.3}{4 \pi}\right)\left(\frac{Q \mu}{k h}\right) \log \left(\frac{t_{s}+\Delta t}{\Delta t}\right)
$$

where $t_{s}$ is the total time of the flow test and $\Delta t$ is the elapsed time since shut-in. A plot of pressure versus the log-term can provide an estimate for the transmissivity $k h$, since all other parameters in the equation are known. Application of this analysis to the shut-in data above indicated a transmissivity on the order of only $25 \mathrm{Da}-\mathrm{m}$, however, the apparent temperature-induced drift in the pressure-measurement electronics and the very small overall pressure increase detract from the validity of this approach for this particular test. In reservoirs with much lower apparent transmissivity, application of the Theis equation would be the preferred method to estimate reservoir properties.

It is informative to note that laminar, axisymmetric, creeping flow in a horizontal fracture is described by an equation similar to the Dupuit formula if the transmissivity is replaced with the quantity $b^{3} / 12$, where $b$ is the fracture aperture. Assuming flow occurs in a single fracture, and using the same numerical values used to estimate the transmissivity, the predicted fracture aperture lies in the range 1-4 mm, which is consistent with fractures observed in the core samples, but much less than the apparent size of the production zone based on drilling data (drillstring dropped approximately 2', without rotation, when it reached this interval.) This indicates that, although we may have penetrated a large void, a much smaller fracture can carry the amount of fluid produced. The ability of the large fracture to carry much more fluid than was actually produced, along with the simulations described below, indicate that the wellbore diameter, not the reservoir, was the parameter limiting flow rate. 
Analysis of spinner data: Spinner data, in some cases, can be the most informative measurement taken in a flowing well. In holes which penetrate several potential production or injection zones, it is frequently difficult to analyze internal flow in the wellbore, and good spinner data can be extremely useful in this aspect of interpretation. Obtaining fine resolution is difficult, however, because spinners are not usually calibrated to give absolute flow velocity, or even velocity relative to the tool, but instead to give a number of counts that measures how fast the impeller on the tool is rotating. In some instruments, such as those used in our tests, it is not even possible to determine flow direction relative to the tool.

There are, however, two features of the test configuration which make it possible to, in effect, calibrate the spinner after the fact: (1) the logging line speed, or tool velocity, is known in all cases, and (2) total mass flow rate is known and, in the casing where flow is single-phase, fluid velocity can be accurately calculated. Combination of the logging tool speed and absolute fluid velocity gives the fluid velocity relative to the logging tool, and repetition of this procedure at several flow rates produces a "calibration curve" for the spinner tool. In deriving these calibration curves, only the cases in which the relative fluid velocity was toward the bow of the spinner tool were considered; generally, we felt that the tool body shadowed the impeller when relative flow was from the tool's stern. Use of these calibration curves to analyze flow test data ${ }^{12}$ revealed that flow from the major production zone at $815^{\prime}$ is divided, with the majority of the fluid going up the well and the remainder going down. The down-going flow rate, which varies from approximately 20 to $50 \mathrm{gpm}$, is a very weak function of the wellhead flow rate.

Simulations: Numerical simulation of flow in a wellbore is critically dependent on the correlation or mathematical model used to describe the two-phase flow regime. Depending on well depth and temperature of the surrounding formation, representation of heat transfer between the formation and the wellbore may be equally important. We are currently investigating the three computational packages described below for numerical simulation of flow in slimholes.

- GEM requires input of downhole pressure, formation-temperature profile, and wellhead pressure, and then calculates flow rate. It allows simulations ${ }^{7}$ with no slip in the two-phase region or with either of the slip models proposed by Orkiszewski ${ }^{8}$ and Hughmark. ${ }^{9}$ In GEM, heat conduction in the surrounding formation is simulated using finite differences.

- WFSA requires input of downhole pressure, formation temperature, and flow rate, and then predicts wellhead pressure. It allows for multiple feed zones and the effects of dissolved solids, is based on the work of Hadgu ${ }^{10}$, and uses a specially developed two-phase flow model. Heat transfer between the formation and the wellbore is described with an analytical model.

- GEOTEMP2 simulates drilling processes, ${ }^{11}$ with some capability for injection and two-phase production. For production, the program requires input of downhole pressure (or temperature and quality, if feed is two-phase), formation temperature, and flow rate, then calculates wellhead pressure. This program uses the Orkiszewski two-phase slip model and treats heat transfer between the wellbore and the surroundings with a finite difference numerical model.

The codes agree reasonably well with each other and with the field data, except that the surface temperature calculated by GEOTEMP2 is noticeably lower than the other codes. All codes predicted transition to two-phase flow at approximately the same point. Effort required to set up the input files, and computer run time (cpu), are similar for all three codes.

Each of these codes can be used to iterate a series of solutions with varying initial conditions to produce a curve of flow rate versus wellhead pressure, along with the associated predictions of downhole pressure and temperature. This predictive capability can be scaled up to a 
larger well in the same reservoir, if we assume that the downhole pressure remains the same. In this highly permeable situation, that assumption was valid, but in other reservoir types the pressure drawdown during production might seriously distort the predicted output. This phenomenon emphasizes the need for a coupled wellbore-reservoir simulator.

Both GEM and WFSA were used for our initial simulations of flow in the slimhole. In Figures 4 and 5, the pressure and temperature distributions with depth, assuming adiabatic flow, are compared with downhole measurements for the first test series (well depth is 968'). The GEM simulations used the Orkiszewski two-phase flow option. Most of the calculations are in good agreement with the measurements, but near the surface we suspect that unmodeled heat transfer mechanisms are responsible for the difference between predictions by WFSA and observed temperature distributions: The two-phase flow correlation used in GEM apparently causes it to under-predict wellhead pressure, as shown in Figures 5 and 7, and there is a slight variation of temperature with depth in the single-phase region, shown in Figure 4, as contrasted with the constant-temperature assumption in WFSA; otherwise, temperature and pressure distributions predicted with GEM differ little from those predicted with WFSA.

Predictions made with GEM and WFSA of wellhead pressure as a function of mass flow are shown in Figure 7, and those predictions are compared with the experimental measurements from all flow tests. The WFSA prediction compares best with the experimental data; although the simulation has a local minimum, most likely attributable to a change in flow correlation, near a flow rate of $6 \mathrm{~kg} / \mathrm{s}$. The GEM prediction, using the Orkiszewski correlation, consistently underpredicts the pressure, but if the downhole pressure at the feed zone is increased by $5 \%$, the GEM prediction then passes through the experimental data. The prediction from GEM using the Hughmark correlation tends to agree with the WFSA prediction for mass flow rates less than 6 $\mathrm{kg} / \mathrm{s}$, but predicts significantly lower wellhead pressures for larger flow rates. The agreement among the computational approaches and experimental data is reasonable, considering the variability of the measurements involved and the sensitivity of the simulations to the two-phase flow correlations employed. These comparisons should be viewed as preliminary since we are still evaluating various approaches to the simulation of wellbore flows.

Keeping all parameters except wellbore diameter fixed, GEM and WFSA predictions were applied to a full size production wellbore with diameter of 12.25 inches. For a mass flow rate of 62 $\mathrm{kg} / \mathrm{s}$, wellhead pressures of 56,66 , and 55 psia were predicted, respectively, with WFSA, GEM(Orkiszewski), and GEM(Hughmark). The flow rate of $62 \mathrm{~kg} / \mathrm{s}$ corresponds to a 1990 test $^{2}$ of the nearby 12.25" production well Hot Air-4 (HA-4), which produced 900 gpm of liquid water at a wellhead pressure of 72.5 psia. When corrected for flashing, that measured flow rate corresponds to a total mass flow rate of approximately $62 \mathrm{~kg} / \mathrm{s}$. The production from well HA-4 is associated with a production zone at 729', which is somewhat shallower than the slimhole production zone at $815^{\prime}$. However, tracer tests in the Steamboat Hills geothermal field indicate pervasive interconnections between fracture zones, so it does not seem unreasonable to expect similar production rates among nearby fracture zones. Based on a single test, simulation of a production well extrapolated from a slimhole tends to indicate a lower wellhead pressure at a specified mass flow rate than that observed experimentally. The results are, however, encouraging since the differences appear to be within a normal range of variation for the experimental measurements and the models used in the simulations.

\section{DISCUSSION}

Drilling is cheaper for slimholes than for production wells because the rigs, crews, locations, and drilling fluid requirements are all smaller; because site preparation and road construction in remote areas is significantly reduced, up to and including the use of helicopter-portable rigs; and because 
it isn't necessary to repair lost-circulation zones before drilling ahead. As a comparison, the Steamboat Hills slimhole, including all testing and overhead, cost approximately $\$ 150 /$ foot while the neighboring production well (12-1/4" production diameter) cost $\$ 377 /$ foot. Although the slimhole's greater total depth reduced its overall cost per foot, the intermediate cost of drilling the slimhole to the same depth as the large well was less than $60 \%$ of the large well's total cost.

If the resource evaluation program calls for production or injection tests from an exploratory well, these are also easier with a slimhole because they involve handling much less fluid than a larger well. Finally, the same attributes that reduce the cost also greatly reduce the environmental impact. As exploration expands into new areas such as the Pacific Northwest, this may become the critical criterion in regulatory agencies' decisions on whether to issue permits. This technology appears to be the best hope of increasing exploration in an attempt to enlarge the nation's proven geothermal reserves.

\section{CONCLUSIONS}

We believe that field results validate our testing strategy for this slimhole. Because drilling and testing conditions are so site-specific, we do not claim that the procedures described here are a universal recipe, but this is a solid first step toward developing a general method for slimhole exploration. In particular, we have compared test measurements with wellbore models, and have made a convincing case for the ability to predict flow in this type of reservoir.

We have reached the following conclusions concerning slimhole testing; the last two items below are specific to the Steamboat Hills geothermal field and the others are more generic.

1. Slimholes can be flow-tested, with successful surface and downhole measurements. Relatively cheap and simple surface measurements (James tube and weir box) can give flow rate and enthalpy.

2. The internal flow in the wellbore (described in the section on spinner data) greatly complicates the analysis of attempted pressure transient (build-up or fall-off) tests. This emphasizes the need for better definition of intra-wellbore flow.

3. The strategy used for these tests appears to have produced the necessary test data, taken with appropriate accuracy, to evaluate the commercial potential of a larger well at this location.

4. Numerical simulation of flow in the wellbore can yield a predictive curve of flow rate versus wellhead pressure, as shown in the slimhole data. Applied to a larger diameter well, this same simulation will give the same kind of production curve, giving a measure of the reservoir's commercial potential. Extrapolation from the slimhole data to the wellbore diameter of a nearby production well gave a reasonable estimate of the larger well's actual flow rate for a given wellhead pressure.

5. It is desirable to develop a coupled wellbore-reservoir simulator, and to extend this exploration strategy into other reservoir types, to validate the predictive capability of that model.

6. The deeper, hotter reservoir postulated in this location was not encountered down to 4000'. There is, however, significant permeability below the $815^{\prime}$ production zone, implying that water hotter than $300^{\circ} \mathrm{F}$ can be pumped from deeper zones, or water from a power plant could be injected into these zones. 
7. The existing reservoir is extremely permeable; calculations of transmissivity are probably lower bounds.

\section{RECOMMENDATIONS}

Although the test results here are encouraging, the highly fractured, highly permeable, reservoir may not be generally representative of other geothermal resources. The next step in the slimhole program should be exploratory drilling and testing in reservoirs with different flow characteristics, and comparison of those results with production wells in the new reservoirs. From preliminary negotiations with geothermal operators, we are confident that this can be done, given adequate funding in the near term.

A consequence of moving to other types of reservoirs will be the increasing need for better modeling capability, especially in terms of coupling a reservoir simulator to a wellbore simulator. As described in Section VI, the assortment of wellbore models used to date give reasonable predictions of flow behavior, but the codes' performance is enhanced, or perhaps even made possible, by the extreme transmissivity of this specific reservoir, which allows the assumption of a fixed pressure at the feed zone to be realistic. In other reservoirs, this may not be the case. We recommend, therefore, that a coupled reservoir-wellbore model be developed to aid further analysis.

There are also areas in which the instrumentation and data-collection strategy used in these tests could be improved. An enhanced instrumentation development could be a collaborative effort between Sandia and industry, or could be stimulated in industry alone by increased commercial slimhole exploration. Specifically, the following concerns should be addressed:

- Spinner measurements should be done with a tool which can distinguish flow direction (up or down); this feature is presently available in some commercial logging services, but is not always used. Data from most spinner tools is probably only good when the tool is moving bow-on into the flow (logging down), so data acquired logging up (flow stern-on) should be disregarded. Logging at a slower line speed will increase the probability that flow is bow-on to the tool, but the lower relative velocity makes the spinner more likely to stick. Careful analysis of the internal flow seems to be more important for slimhole exploration than in conventional production-size well testing because of the increased emphasis on down-hole instrumentation in the slimhole testing.

- As an aid to interpretation of the internal flow, accurate static pressure-temperature logs should be run at regular intervals, particularly when drilling data or core indicate that new high-permeability zones have been penetrated. Examination of the points on these logs where deviation of the pressure gradient coincides with changes in the temperature gradient should reveal sources and sinks of intra-wellbore flow.

- Optimum logging speed should be established; most of the service companies run their tools at 50 to $100 \mathrm{feet} / \mathrm{min}$, which may be too fast for the pressure and temperature resolution needed in comparison of modeling and field data.

- Data drift caused by internal heating of the downhole electronics became significant because of the distortion of the data and because of the limitation this placed on the time available to do certain tests, particularly pressure transients. If these tests are thought to be valuable, a different testing technique, perhaps capillary tubing from the surface, or the use of tools with longer high-temperature residence times may be necessary. 
- During development of slimhole testing methodology, commercial PTS logging tools should do static temperature logs at the beginning and end of each test series. These temperature logs could then be compared with some reference standard, such as the Sandia temperature tool, to evaluate the drift in the tool during the tests.

- Static water level in the well should be measured at regular intervals, probably daily, to keep track of the formation pressure in the permeable intervals penetrated to date.

Finally, the experience during the Steamboat Hills project showed the value of real-time, on-site data analysis. Software which could have compared downhole data with a wellbore simulator during the test sequence would have indicated malfunctioning instrumentation, or reservoir anomalies, quickly enough to have either taken remedial action or have changed the testing methodology appropriately.

\section{BRIEF GEOLOGIC DESCRIPTION (after reference 13)}

The Steamboat Hills geothermal area, which covers approximately four square miles and includes active hot springs and fumaroles, has been studied for several decades. The oldest known rocks in this area are metamorphosed sedimentary and volcanic rocks, known collectively as the Peavine sequence. These rocks outcrop south and west of the drill site, and are believed to be of Triassic-Jurassic age.

The Peavine sequence is extensively intruded by Cretaceous-age plutonic rocks, of which granodiorite is the most abundant. There are also numerous outcrops of the granodiorite around the drill site. Next oldest are the Tertiary Alta and Kate Peak Formations. These formations primarily comprise volcanic flows, mud flow breccias, and sedimentary deposits. The Alta Formation is approximately 22 million years old (myo) and the Kate Peak is about 13 myo.

Youngest rocks are the Quarternary flows, domes, and sedimentary deposits, including the Steamboat Hills Rhyolite, believed to be associated with four small domes on a line that runs southwest to northeast of the drill site. A so-far-undetected shallow rhyolite intrusion is believed by some to be the heat source for the Steamboat Hills hydrothermal system.

All the different rocks in the Steamboat Hills geothermal area have been hydrothermally altered to a greater or lesser extent. Hydrogen sulfide rises, oxidizes to sulfuric acid and chemically attacks silicate minerals, replacing them with opal and cristobalite. Below the water table, silicate minerals are generally replaced by alunite and kaolinite.

Three principal lithologies were penetrated during drilling: Quaternary hot spring siliceous sinter deposits with intercalated alluvium; a series of Tertiary volcanic breccias and lahars; and an extensive Cretaceous-age granodioritic plutonic complex. Minor lithologic features include at least two andesite dikes, a probable ash fall or siltstone, pervasive calcite-chlorite veining, druzy quartz veins, stibnite, pyrite, and other sulfide mineral deposits, xenoliths, and possible plant fossils within the siliceous sinter.

Structurally, the pre-Cenozoic metamorphic rocks are intensely folded and faulted. Dips range from 45 to 90 degrees, while bedding strikes range from northeast to northwest. At least three systems of normal faults have been recognized in the Steamboat Hills. One set, which is still active, strikes northeast, parallel to the axis of the Hills. Another set strikes northwest, almost perpendicular to the first set. The third set of faults strikes nearly north and is prominent on the main terrace of hot springs. The Steamboat Hills hydrothermal system has been active, possibly intermittently, for approximately the last 2.5 million years, and faulting appears to be the principal structural control for fluid flow. 


\section{GLOSSARY}

The following terms are common in drilling practice and are used in this report:

Bowlin spear - a fishing tool which expands inside a fish when the drillstring is pulled up

BOP - blow out preventer: one or more devices used to seal the well at the wellhead, preventing uncontrolled escape of gases or steam

cave - debris that falls off the wellbore walls and accumulates in the bottom of the hole

fish - any part of the drillstring accidentally left in the hole

fishing - trying to retrieve a fish

float collar - a coupling with check valve; placed near the bottom of a casing string to prevent the heavy cement column in the annulus from flowing back into the casing after displacement

Geoset - a type of synthetic diamond cutter used in impregnated bits

$\mathrm{H}$ or $\mathrm{HQ}$ - designation of a coring tool size; rod outside diameter is 3.5 ", bit is approximately 3.8 " OD and 2.5" ID

$\mathrm{H}_{2} \mathrm{~S}$ - hydrogen sulfide; a poisonous gas frequently found in geothermal drilling

jars - tools which apply an impulse force to the bottom of the drillstring when the string is pulled up; usually used for fishing, but sometimes included in the string for normal drilling

lay down - to take a piece of equipment out of service; e.g., to lay down a worn core rod

LCM - lost circulation material; any material used for plugging formation fractures to avoid loss of drilling fluid

lubricator - sealing element attached to the wellhead which allows a wireline to pass up and down with pressure in the wellbore

matrix - the hard metal portion of a bit which holds the diamond cutting elements in place

$\mathrm{N}$ or NQ - coring tool size; rod OD is $2.75 "$ ", bit is 2.98 " OD and $1.875^{\prime \prime}$ ID (N fits inside $\mathrm{H}$ )

nipple up - to assemble something; usually applied to the wellhead stack

overshot - in general, any tool that latches around the outside top of another tool; usually refers to the assembly which retrieves the core tube with the wireline

PTS - pressure-temperature-spinner tool; downhole instrumentation to measure these quantities (spinner output is an indication of velocity or flow rate) 
pick up - to put any piece of equipment into use; e.g., to pick up a new bit

pitcher nipple - the vertical tube around the top of the blow-out preventer; it collects the drilling mud returns and empties them back into the mud tanks

POOH - pull out of hole; bringing the drill string and tools out of the hole

rams, pipe or blind - rams are part of the blow-out preventer; pipe rams close around the drill pipe if it is in the hole, blind rams seal against each other if the pipe is not in the hole

RIH - run in hole; inserting the drillstring and tools into the hole

sanded in - solid particles, such as cuttings, have filled the annulus between the drill rods and the wellbore, or between the core tube and the outer barrel, locking them in place

shoe - a heavy, tapered cap that attaches to the bottom of the casing string and protects it as the casing is lowered into the hole

spud - to begin drilling a well

stand - more than one joint of drill pipe screwed together; when tripping, pipe is handled in stands to avoid making and breaking every connection - for this rig, a stand was 4 joints

strip - to wear away the matrix in an impregnated diamond bit; the bit must strip to expose the diamond cutting surfaces

swage, inside or outside - a fishing tool which grabs the inside or outside of a fish by forcing an interference fit

trip - any event of pulling the drillstring out of the hole and returning it

wiper trip - running the drill string, with a bit, to the bottom of the hole to make sure there are no obstructions in the hole

WOC - wait on cement, time spent waiting on cement

xover or xo - crossover; a coupling used to adapt from one thread size to another

\section{REFERENCES}

1. J. Combs and J. C. Dunn, "Geothermal Exploration and Reservoir Assessment: The Need for a US Department of Energy Slimhole R\&D Program in the 1990s", Geothermal Resources Council BULLETIN, Nov 1992, pp.329-337

2. C. B. Goranson and J. Combs, "Steamboat Hills Geothermal Field -- Far West Capital, Inc SBII and SBIII Power Plants Lease Area Data Package", 3 vol., 1994

3. M. A. Grant, I. G. Donaldson, and P. F. Bixley, Geothermal Reservoir Engineering, Academic Press, New York, NY, 1982, pp. 116-125

4. Teklu Hadgu, et. al., "Preliminary Report on Recent Injection and Flow Tests in Well SNLG 87-29 Steamboat Hills Geothermal Field, Nevada," Draft, Lawrence Berkeley Laboratory, Berkeley, CA, Dec. 1993 
5. G. de Marsily, Quantitative Hydrogeology, Academic Press, Orlando, FL, 1986, pp. 147-149

6. ibid, pp. 162-163

7. R. C. Dykhuizen and R. R. Eaton, Modeling of Geothermal Wells With GEM, Memo to J. C. Dunn and J. T. Finger, dtd. 1/8/93, Sandia National Laboratories, Albuquerque, NM

8. H. Orkiszewski, "Predicting Two-Phase Pressure Drops in Vertical Pipe," J. Petr. Tech. 1980, pp. 829838.

9. G. A. Hughmark, "Holdup in Gas-Liquid Flow," Chem., Engr. Prog., 58(4), 1962, pp. 62-65.

10. T. Hadgu, Vertical Two-Phase Flow Studies and Modelling of Flow in Geothermal Wells, $\mathrm{PhD}$ Thesis, Univ of Auckland, New Zealand, 1989

11 L. A. Mondy and L. E. Duda, "Advanced Wellbore Thermal Simulator GEOTEMP2 User Manual," Report SAND84-0857, Sandia National Laboratories, Albuquerque, NM, Nov 1984

12. R. R. Eaton and C. E. Hickox, Analysis of Steamboat Hills Spinner Data, Memos to J. Finger, dtd 1/11/94, 1/12/94; Sandia National Laboratories, Albuquerque, NM

13. T. Flynn, P. K. Buchanan, J. D. Miller, "Core Lithology and Photographs, Slimhole SNLG 87-29, Steamboat Hills, NV"; Division of Earth Sciences, University of Nevada, Las Vegas; Las Vegas, NV 89154; Sandia National Laboratories Contractor Report 


\section{APPENDIX A}

The following day-by-day log represents notes made by Sandia personnel at the times of the events described. Definitions of abbreviations and jargon are given in the Glossary, Section IX. This narrative is complementary to the Daily Drilling Reports given in Appendix B. 


\section{Jul 93}

Continue rigging up, most components of rig are here and assembled. Road and pad are prepared and water line is laid from injection well to location.

1630 - Picked up 12-1/4" roller-cone bit and spudded hole. Drilled to approximately $3-1 / 2^{\prime}$ and cemented short piece of $9-5 / 8 "$ casing for mud riser. WOC till morning.

\section{$21 \mathrm{Jul} 93$}

0700 - Complete rigging up: tie down guy wires, connect pumps, etc. Weld pitcher nipple to mud riser.

1400 - Finally finish welding nipple. Hold $\mathrm{H}_{2} \mathrm{~S}$ safety meeting.

1600 - Begin drilling HQ; losing some circulation.

1650 - First 5 ' core out; $100 \%$ recovery. Drilling second $5^{\prime}$ tube, will pick up $10^{\prime}$ tube for next run. Still losing circulation but under control.

\section{Jul 93}

0700 - Have cored HQ to 161 ', with clay zone near bottom. Will core another 5', trying to get into more competent formation for casing shoe.

1100 - Reach 172', circulate hole. POOH with HQ.

1400 - Pick up 8-1/2" roller-cone bit and begin reaming HQ hole. Reaming is slow at first because of hard formation near surface and because can't get much weight on bit. Casing arrives: 4 joints nominal $42^{\prime}$ lengths. Cut off approximately $2^{\prime}$ to make cementing head, but remaining casing adds up to 167.3' with float and float collar. Requires drilling about 4 ' past bottom of core hole to make casing length reach the proper height for cementing.

\section{Jul 93}

0700 - Drill to casing point, make wiper trip and circulate hole. Lay down 8-1/2" tools and start running casing. Casing is fairly tight, but does get down to calculated height.

1300 - Nipple up cementing head and begin circulating through casing. Bottoms-up temperature is $135^{\circ} \mathrm{F}$. Mixing cement: Portland, $40 \%$ silica flour, friction reducer.

1530 - Pump 49 cu. ft. cement, release plug, and displace with water. WOC.

\section{Jul 93}

0130 - Checked cement in sample cups and it appears to be curing properly.

0400 - Welder arrives for wellhead. 
0800 - Begin nippling up BOP. Accumulators are electrically connected and plumbing is complete except for final connections to BOP.

1330 - Completed pressure tests on BOP; pipe and blind rams each pressurized to 500 psi for 15 minutes, each fell off slightly but held enough to pass test. Tests witnessed and approved by Dick Whiting, Nevada Department of Minerals. Begin picking up 5-1/2" core rods for coring BSF (6-1/4") hole.

1600 - Tagged top of cement at 110'. Begin drilling (coring) out cement.

1830 - Drilled through float collar at 132 '.

2230 - Drilled through shoe at $173^{\prime}$.

\section{Jul 93}

0800 - Coring ahead at $212^{\prime}$; getting fairly good core recovery, but still a lot of clayey, highly altered formation.

0845 - Coming into top of granodiorite at about 220'.

0930 - Complete lost circulation at about 225'; losing about $40 \mathrm{gpm}$.

1030 - Regained about $40 \%$ returns.

1300 - Coring ahead at 240'; lost returns averaging $40-60 \%$.

1730 - Begin bit trip from $255^{\prime}$.

\section{Jul 93}

0700 - Coring ahead at $295^{\prime}$; ROP is $5-6 \mathrm{ft} / \mathrm{hr}$, but there was a trip to lay down a bad rod which apparently snagged the wireline and broke it. Getting nearly full returns.

0900 - Longyear safety meeting: all Sandia personnel attended.

1300 - Coring ahead at $320^{\prime}$.

1800 - Coring ahead at $345^{\prime}$.

\section{Jul 93}

0700 - Coring ahead at 414'; drilling well but mud returns have gotten hot (about $165^{\circ} \mathrm{F}$ ).

1200 - Fluid temperatures have dropped some, probably aided by the "cooling tower" built on the mud tank. Hole appears to be producing some fluid; viscosity is down, chlorides are up, and flow instrumentation shows frequent excess returns. 
1730 - Coring ahead at $451^{\prime}$; returns have dropped back to about $147^{\circ} \mathrm{F}$ and hole doesn't seem to be either taking or losing fluid

\section{Jul 93}

0700 - Coring ahead at $495^{\prime}$. Returns temperature stabilized at $\sim 145^{\circ} \mathrm{F}$. Bit change at $462^{\prime}$; inside gage on old bit was completely gone.

0915 - Complete lost circulation at 507'; pumping LCM.

1215 - Regained returns after slugging hole with paper, cedar fiber, and cottonseed hulls.

1400 - Flash tank arrives from Mammoth Lakes; 4-1/2" casing arrives from Longyear. Mud pump is down, plugged with fragments of a rubber glove. These fragments have been showing up in the mud system since the first day, and it is not obvious where they're coming from.

1600 - Complete loss of returns again, still from the same fracture as before. Trying to get below it to try sealing with LCM or cement. Core returned from this interval shows a massive fracture, approximately 3 " wide, filled with calcite but broken either in the formation or in the core barrel.

$1800-\mathrm{POOH}$

1900 - Cement mixing tank on the rig floor. Will pump open-ended through H-rod, leading with a slug of cottonseed hulls. Tracking static fluid level with echo-meter; now about 160'.

2100 - Mixing 10 sacks cement; pipe on bottom. Will pump next to fracture.

2200 - Pump cement and POOH. WOC.

\section{Jul 93}

0700 - Cement has set and hole is holding fluid. Tag cement with drill pipe at $\sim 480^{\prime}$. POOH with H, RIH with 5-1/2" pipe and clean out cement with 6-1/4" bit. Drill ahead to 525'; this depth will allow the televiewer to get deep enough to view the fracture, and will make the casing length come out correctly.

1300 - Rigged up for temperature log; RIH through drill pipe and out bit. Will do another log after pipe is out of hole. Most of hole shows less than $90^{\circ} \mathrm{C}$, with temp slightly over $100^{\circ} \mathrm{C}$ when the probe rests on the bottom of the hole.

1400 - Laying down 5-1/2" drill pipe.

1800 - Run another temperature log with pipe out of hole; similar to first log. Running in hole with $\mathrm{H}$-rod, will circulate briefly and then run televiewer.

2300 - Televiewer log complete and successful. Fractures were evident, mostly dipping southwest, although some were at other orientations, including northeast. 
2330 - Rigging up to run 4-1/2" casing and pump cement.

\section{Jul 93}

0300 - Ran casing to 524' and pumped $120 \mathrm{cu} \mathrm{ft}$ cement mixed 1:1 with perlite. tailed with neat cement. Got returns (perlite) but formation apparently broke down and cement fell back.

0800 - Surface cement samples show that cement has not even begun to set. Call to Halliburton office reveals that cement included a fluid-loss additive which also acts as a retarder. Howco engineer estimated 16-20 hours for a surface sample to harden. At $160^{\circ} \mathrm{F}$ or greater, however, it should start to set in 6-8 hours (i. e. cement in hole should be starting to set.)

1000 - Rig up for temperature log.

1100 - Put "cold" water down the annulus and log again Hole takes water freely at first, but soon slows down to $<1 \mathrm{gpm}$. Log shows that upper part of hole has cooled considerably, but no cooling below $\sim 220^{\prime}$

1600 - Repeated logs, while continuing to trickle "cold" water down the annulus, show the upper hole continuing to cool, with all temperature lines crossing at about $220^{\prime}$. Perforating crew is on the way; will perforate from about $230^{\prime}$ to $220^{\prime}$. Nippling up BOP to do pressure test before perforation.

\section{Jul 93}

0400 - Pressured up blind rams/wellbore to test BOP; small leaks in various valves.

0800 - Complete pressure tests (500 psi for $30 \mathrm{~min}$ ) on blind rams and pipe rams. Rigging up to perforate from $230^{\prime}$ to $220^{\prime}$. Perforations complete, water level fell to static.

1000 - Rigged up for Halliburton to pump cement through one stand open-ended drill pipe held in the BOP pipe rams. Pumped cement until we got good returns at surface $(\sim 85 \mathrm{cu} \mathrm{ft})$, shut off cement and pumped $70 \mathrm{gal}$ mud through drill pipe with rig pump. This is the calculated volume to displace cement out of drill pipe and halfway down casing to perforations. Shut in drill pipe. Kept filling annulus with cement from top as it fell back, but very little $(<10$ gal) was required. Released Halliburton. WOC.

1800 - RIH with HQ tools and clean out to top of firm cement. Core ahead, look at cored cement samples, it appears well cured and competent. Drill ahead.

\section{Aug 93}

0700 - Have drilled past perforations to float collar. Pressure test to $100 \mathrm{psi}$ at the wellhead. Perforations do not leak. Drill ahead.

1130 - Drill contact between cement and formation. Very good interface, no signs of mud contamination or other problems. Run temperature log in Hot Air \#4 (production well next to corehole); log is the same shape as previous log (last year) and matches maximum temperature $\left(339^{\circ} \mathrm{F}\right)$. 
1730 - Coring ahead in granodiorite at 575'.

\section{Aug 93}

0330 - Lost circulation at 637', drilled ahead enough to get core from that depth, core had some fractures but none that appeared to have had large water flows. Circulated LCM and regained partial $(\sim 50 \%)$ returns. Consensus is that this fracture is too small to try a flow test.

1400 - Continue rigging up equipment for flow/injection tests.

2000 - Still coring ahead at $718^{\prime}$, formation continues to be fractured with returns varying from $50 \%$ to $10 \%$, but still have not encountered the total and irretrievable loss expected near this depth.

\section{Aug 93}

0700 - Coring ahead at 783'; same as above. Some returns, no massive loss.

1100 - Drilling break at 816'; driller lowers string 2+ feet without rotating, water level falls below $300^{\prime}$. Complete loss of returns. Recover 7.4' core in 10' run. Will drill ahead, and get next core run, then drill some rathole below fracture.

1415 - Drilled to 838, $\mathrm{POOH}$ and began nippling up flow tee and connections.

1800 - Run temperature log while flow connections in progress; hole has cooled by $40^{\circ} \mathrm{F}$ compared to log after first cement on 4-1/2" casing (i.e., flow may be hard to start).probably because of pumping lots of cold water into formation with no returns.

2100 - Pressured up to $100 \mathrm{psi}$ at wellhead, let sit for an hour, and released pressure. Well did not flow. Ran temperature log, well had heated up approximately $30^{\circ} \mathrm{F}$ since previous log.

2230 - Repressurized wellhead to $100 \mathrm{psi}$, will leave until 0630.

\section{Aug 93}

0700 - All instrumentation working, release pressure on wellhead, well does not flow. Try 8 cycles of pressure/quick release, well still does not flow. Will try to get higher-pressure compressor to force fluid deeper.

0930 - New compressor pumps 205 psi at wellhead, leave pressurized for 30 minutes and release, well still doesn't flow.

1030 - Re-configure wellhead so that we can drill with flow tee in place. Test vortex flow meter against weir box; have good agreement.

1215 - Since there is apparently low permeability and/or little fluid in fractures, we will drill ahead to a more promising opportunity. 
2000 - Drilling ahead at 878'

\section{Aug 93}

0700 - Drilling ahead at $958^{\prime}$. Core from $868^{\prime}$ down contains many steeply-dipping, highly mineralized fractures that do not fit closely when core is reassembled. This indicates that there should be significant apertures downhole in this interval.

0750 - Pull back into casing and rig up to do temperature log to bottom at 968 '.

0900 - Log shows high temperature $\left(>160^{\circ} \mathrm{C}\right)$ in fractured interval from $868^{\prime}$ to $948^{\prime}$, indicating high permeability in that interval.

1015 - Will pull back to about $200^{\prime}$ and try air-lifting from inside casing. Compressor is rated at 100 psi, 100 scfm.

1300 - Air lift is producing about $4-5 \mathrm{gpm}$, outflow temperature has risen from about $135^{\circ} \mathrm{F}$ to $162^{\circ} \mathrm{F}$.

1500 - Outflow temperature is up to $180^{\circ} \mathrm{F}$, but the small annulus between the $\mathrm{H}$-rod and wellbore will probably prevent flow even if temperature gets near boiling. Will pull rods and pressurize wellhead.

1600 - Left wellhead at 100 psi for $30 \mathrm{~min}$, released pressure, well did not flow. Will run back in with $\mathrm{N}$-rod (2-3/4" OD) and air lift again, hoping that the larger annulus will allow lifting more water. Rig for temperature log through N-rod before air-lift.

1700 - Temperature log shows temperatures below about $150^{\prime}$ almost identical to yesterday's last log. Begin air lift with 100 psi compressor. Temperature in flow line reaches about 1990 , flow rate $\sim 25-28 \mathrm{gpm}$.

1800 - Add larger compressor ( $200 \mathrm{psi}, 300 \mathrm{scfm}$ ) into line - compressors in parallel. Temperature drops to $190^{\circ} \mathrm{F}$ and flow rates becomes very erratic, from 12 to $28 \mathrm{gpm}$. Speculation is that both compressors are blowing too much air past the water. Will take small compressor out of the circuit.

1821 - When both compressors are turned off, well begins to flow on its own. Temperature goes to $203^{\circ} \mathrm{F}$ and flow rate remains erratic at $10-30 \mathrm{gpm}$, probably because of the drill pipe in the hole. Let the well flow to clean up the fluid (get rid of drilling mud, etc.) and shut in.

$\mathrm{POOH}$ with $\mathrm{N}$-rods and pressurize wellhead to $150 \mathrm{psi}$ with compressor.

2008 - Release wellhead pressure and well flows. Beginning flow rate indicated on magmeter is approximately $60 \mathrm{gpm}$ (liquid), but it builds to $100+\mathrm{gpm}$ within 25 minutes. Actual flow from well does not take this long to stabilize, but time for reaching steady-state conditions between the flash tank and weir box causes readings to lag flow.

2130 - Rigging up to run wireline pressure, temperature, spinner (PTS) logs. Spinner log shows most production from major fracture at $815^{\prime}$. 
2250 - Choking flow to approximately $80 \mathrm{gpm}$ by closing wellhead valve; flow rate and wellhead temperature go down, wellhead pressure goes up.

2327 - Choke to approximately $50 \mathrm{gpm}$.

\section{Aug 93}

0010 - Open valve for full flow.

0039 - Shut well in.

0700 - Open well, POOH with downhole PTS tool, RIH with downhole fluid sampler, take water samples below production zone, $\mathrm{POOH}, \mathrm{RIH}$ with SNL temperature tool, temperature log, rig up for injection test. Injection will be hot $\left(\sim 195^{\circ} \mathrm{F}\right)$ water from power plant injection line, step-wise injection at four flow rates (maximum first, then step down and back up), then shut in.

1345 - Start injecting at about $470 \mathrm{gpm}$, drawing water from the power plant injection well line. Water temperature is $>220^{\circ} \mathrm{F}$, so it's flashing to steam in the injection line because of low back pressure.

1430 - Increase flow rate to $630 \mathrm{gpm}$; wellhead pressure is about $26 \mathrm{psi}$.

1500 - Stop injection; line has blown off injection pump. Consensus of personnel here is that they don't trust hose again at high temperature; we will rig up to inject cold water.

1610 - Start cold water injection. Inject at three flow rates: 260,500 (start at 1640), 600 (start at 1716) gpm; get data from all runs. After flow stabilizes at each rate, run logging tool up and down interval from $805^{\prime}$ to $960^{\prime}$ trying to define where the water is going below the production zone. Shut in well, do static downhole log, and log out of hole.

1900 - Resume drilling.

\section{7/8 Aug 93}

Have drilled from $978^{\prime}$ to $1232^{\prime}$ in these two days. We are, in general, looking for potential production zones while waiting for logging tools to be repaired and/or calibrated. When we do the next set of tests, it is likely that production test results will be very similar to the first set because the large production at $815^{\prime}$ may suppress flow from lower zones.

\section{Aug 93}

0900 - Received downhole packers for isolating flow zones in wellbore. If packers are run in hole on $\mathrm{N}$-rod (2.75" OD) the annular area will permit injection down the annulus and down the rod, allowing comparison of injectivity above and below the packer. This test will be done after the next production/injection series.

1200 - Drilling ahead at 1328'. Will continue drilling until logging tools are available for tests. 


\section{Aug 93}

0700 - Drilling ahead at 1478 , good rate of penetration (up to $10 \mathrm{ft} / \mathrm{hr}$ )

1255 - Begin POOH for bit change at 1510'; rig up for temperature log with SNL tool.

1530 - SNL log over; RIH with N-rod to begin air-lifting fluid for production test. Using small (100 psi) compressor, we are lifting about 20-25 gpm from the hole.

1630 - Well starts self-flowing at $\sim 30 \mathrm{gpm}$; shut off air. Will let well flow briefly to get hot, then kill.

1700 - POOH with N-rod, pressurize wellhead to $100 \mathrm{psi}$, rig up loggers.

1734 - Release pressure, well does not flow; repeat pressurized to 150 psi for 15 minutes (until 1600) well still did not flow.

1830 - Pressurized to 150 psi for 30 minutes; well still did not flow. Run temperature log; will RIH with N-rod and air-lift again.

2000 - Begin air-lift; will lift for $\sim 2$ hours.

2200 - POOH with N-rod, pressurize wellhead.

2245 - Release pressure, well flowing at $85+\mathrm{gpm}$.

2300 - Flow rate readings are no good because weir box is overflowing; suction pump is not working to drain back side of weir. Drain weir box overflow into trash pit and pump into drilling sump. Continue flow.

\section{Aug 93}

0215 - Do PTS traverse in wellbore (up and down) and shut in well.

0730 - Open wellhead, POOH with logging tool, and rig up for injection test Will do hot water injection into full hole first, followed by injection into zones isolated by packer.

0918 - Begin flow at $\sim 335 \mathrm{gpm}$ with $195^{\circ}$ water; wait for flow to stabilize.

1034 - Hose blows off injection pump. Test over, got good data from test, but only at one flow rate. Begin re-plumbing pump with pipe to replace hose, rigging up to run packers.

1730 - RIH with packer on N-rod, set packer at $690^{\prime}$, between production zone at $815^{\prime}$ and apparent injection. zone at $\sim 640^{\prime}$.

1817 - Begin pumping $202^{\circ} \mathrm{F}$ water down the annulus outside the drill pipe at $220 \mathrm{gpm}$. Log down pipe, through packer, and into open hole. Data are anomalous, temperature appears almost constant through packed-off zone. 
1928 - Log out of hole and stop pumping. Pull up on drill string and get no resistance. Packer is deflated. POOH with packer and lay it down.

2030 - Disassemble packer; O-rings at the ends of the inflation element are stretched and gummy, indicating that they were not suitable for high temperature. Will get Viton $\mathrm{O}$-rings and refurbish both packers.

$2100-$ RIH to resume drilling at $1510^{\prime}$.

\section{Aug 93}

1900 - At 1600' after drilling throughout the day. Reasonable rate of progress, although drillstring vibration has been a problem. Most likely cause is water inflow to the wellbore, diluting or washing away the mud and creating friction in the upper part of the hole. Have tried pumping mud down the annulus, Tork-Ease on rods, other rod lubricant, and checkout of rig hydraulic system. Both packers re-dressed with Viton O-rings.

\section{Aug 93}

0720 - Drilling ahead at $1670^{\prime}$. Bit has been in use since $1600^{\prime}$. Still some torque and vibration in drillstring.

1300 - Rig up to run televiewer in 3" corehole (TH-2); will use water truck to pump cold water down hole and try to cool BHTV. Centralizers need adjustment; set for 4-1/8", they will not go in smaller hole.

1800 - BHTV runs are successful; get good picture of borehole. Tool has reliable performance at $110^{\circ} \mathrm{C}$, but is about to quit at $130^{\circ} \mathrm{C}$.

\section{Aug 93}

0700 - Drilling ahead at $1750^{\prime}$. Eighty feet since yesterday, with third bit change now in progress.. Still being plagued by drill string vibration; will try slugging hole with LCM to improve the fluid column in the annulus.

1800 - Drilling has improved somewhat, but there is still noticeable vibration in the drillstring. Will continue trying combinations of rod lubricant and LCM.

\section{Aug 93}

1700 - At $1858^{\prime}$ after continued drilling through the day with generally the same problems and performance as yesterday. Still good core recovery, essentially all granodiorite.

\section{Aug 93}

0800 - Have drilled 90 ' since 0800 yesterday. Low rotary speeds $(\sim 100 \mathrm{rpm})$ have reduced vibration, but also penetration. 
0900 - Short trip out of hole to grease rods; using environmentally benign rod lubricant.

1815 - Drilling ahead at $1958^{\prime}$.

\section{Aug 93}

0700 - Just passed 2000'; still on same bit in at 1837'. Performance reasonably good.

1500 - Preparing for flow tests; plumbed system together so that we could compare flow rates in the vortex meter (water injection line from power plant), magmeter (line between flash tank and weir box), and weir box. Magmeter and vortex meter were within 1-2 gpm at $100 \mathrm{gpm}$ flow rate, with weir box indicating $\sim 90-95 \mathrm{gpm}$. Will check level and zero on weir box.

2100 - POOH for bit change.

\section{Aug 93}

0300 - After running back in the hole with a new bit and beginning rotation, drillstring experienced severe torque, enough to stall rotation. Pipe apparently parted then, either from a twist-off or by unscrewing from torque release, but driller did not realize it immediately. Driller sent down wireline overshot to pull core tube, but could not get on it and thought that the "tree" was leaning over. Sent down the tool to set the tree straight, came out, and sent the overshot down again. Latched onto the core tube, but could not get the overshot back through the broken bottom of the drill string. Released core tube, and pulled wireline out of the overshot, leaving about 20' of wire in the hole. Pulled rest of string out of hole, break is about 140 ' off bottom.

0700 - RIH to tag top of fish and find out whether the overshot is on top of the parted pipe or has fallen back into it.

0930 - Good news is that we tag top of fish at top of parted pipe; that is, the wireline release tube and the overshot have fallen into the pipe. This means that we don't have to fish the line. Will RIH with inside swage (piece of N-rod brought to bullet point, with weld bead on the sides), then try to swage into the pipe and retrieve it.

1145 - RIH with swage +1 joint $\mathrm{N}+$ Xover to $\mathrm{H}$ on drillstring.

1330 - Swage goes in fish, try several times pulling 5,000 lb over string weight, but fish stays stuck. Will POOH and build up weld beads on swage.

1600 - RIH with built-up swage. Pull 10,000 lb on fish, still stuck. Work pipe, can't rotate.

1815 - POOH. Will RIH with N-rod outside swage and try to pick up wire and/or overshot.

2330 - Feels as though the tool grabs the overshot and/or wireline, but no fish in the tool when back at surface. Will cut slots and "teeth" in the end of the swage and RIH.

\section{Aug 93}


0100 - RIH with overshot swage; work up and down and rotate

$0400-\mathrm{POOH}$ with wire rope, jar staff, and slide rod.

0430 - Rebuild outside swage to fish release and picker

0500 - Fish for picker and release until 1530 (two trips.) No material retrieved from hole.

1500 - Decide to cut rods 14 ' above core barrel, RIH with cutter

1600 - Call Midway fishing tool, order Bowlin spear, bumper sub and fishing jars. Should arrive at 0600 in the morning

1800 - Cut rods at 2050'; POOH with cutter.

2100 - RIH with inside swage to retrieve cut-off rods.

$2300-\mathrm{POOH}$ with swage and cut rods

\section{Aug 93}

0030 - Lay down 120' H-rods plus 6' cut rod.

0100 - RIH with overshot swage and worked fish.

$0545-\mathrm{POOH}$ with no fish.

0630 - Pick up spear and jars, RIH.

0830 - Lock into fish and jar on fish, after 8 jars fish starts to move up hole.

0900 - After pulling up three stands with $8000 \mathrm{lb}$ over pull, weight drops to string weight.

1030 - POOH; no fish on spear.

1100 - Pick up inside swage to try to lock into fish and rotate, RIH.

1230 - Tag fish $120^{\prime}$ of bottom and push back to bottom to set swage.

$1300-\mathrm{POOH}$ with fish.

1440 - Fish on deck; got all but 2 bit segments and the overshot release.

1500 - Run open hole temperature log while reworking core barrel. Bit is burned and tube is sanded in. After checking it appears sand came from bad mica LCM

1900 - RIH with new bit and wash to bottom

2300 - Core $1 \mathrm{ft}$ and retrieve tube. 


\section{Aug 93}

0030 - Tube contains both missing bit segments and l' of core

0830 - Cored $41 \mathrm{ft}$ since fishing, vibration problems in upper hole. Pull and grease 12 stands.

1600 - Drilling void at 2149'; short run (blocked). Drilled 3.2' - recovered 2.6', then drilled 6.9' and got 7.6'. Lots of cave. BHT $=316^{\circ} \mathrm{F}$

2200 - At $2168^{\prime}$ bad vibrations, pull back and grease rods.

2240 - Try to drill but won't go; POOH for bit change. RIH with series 8 bit at $2168 \mathrm{ft}$.

\section{Aug 93}

0030 - Still won't go. POOH to grease rods at 2168'.

$0830-\mathrm{POOH}$ for stuck inner tube at 2188'. Roll pin on latch head loose, bit looks like new.

$1645-\mathrm{POOH}$ for pressure and vibration at $2203^{\prime}$. Bit OK but water-ways plugged. Function test BOP. Grease rod on RIH. BHT $=314^{\circ} \mathrm{F}$.

2115 - Back on bottom drilling.

\section{Aug 93}

0800 - Drilled 50' last 24 hours, going slow but with less vibration.

1200 - Run SNL PTS tool tests in TH-2, ran tool for 3 hours. Pressure is stair-stepped because of potentiometric transducer, but temperature and spinner are working.

1300 - Pulled back 13 stands and greased rods. TD at $2268^{\circ}$

1500 - Postpone flow tests until we can solve hole vibration and torque problems. Try to test in a week.

1600 - Pull back and grease 20 stands at 2278'.

2120 - Grease not lasting, pull back 25 stands and grease at 2288.

\section{Aug 93}

0015 - Grease not lasting. POOH from 2293 to check bit. RIH and grease from core barrel all the way with grease loaded with Tork-ease and inverted pipe order - newest pipe now on bottom.

0800 - At 2298'; have drilled 60' in last 24 hours. Rods spinning smoothly, Tork-ease or pipe order may have helped. 
$1015-\mathrm{BHT}$ is $310^{\circ} \mathrm{F}$ at $2318^{\prime}$. Drilling is good with $300+\mathrm{rpm}$.

1100 - Start planning for possible hole size reduction to NQ if drilling does not improve. Would cement bottom of old HQ casing shoe, stretch pipe, and weld donut in BOP flange. Looking for pipe and bits. Won't reduce until after next flow test or later.

$2215-\mathrm{BHT}$ is $318^{\circ} \mathrm{F}$ at $2358^{\prime}$; rods still spinning.

\section{Aug 93}

$0815-\mathrm{BHT}$ is $315^{\circ} \mathrm{F}$ at $2398^{\prime}$.

1510 - Pressuring up, looks like bit is gone. $\mathrm{POOH}$

1700 - Bit is rung, center has groove 1/4" deep. Will service rig then RIH with series 9 bit while greasing rods with Tork-ease and rod grease.

1955 - On bottom drilling with good rotary speed.

\section{Aug 93}

0040 - Drilling 5 hours for 11'; POOH to check new bit.

0300 - Bit like new but matrix is not stripping, pick up series 7 and RIH while greasing.

0545 - Back on bottom drilling.

$0720-\mathrm{BHT}$ is $315^{\circ} \mathrm{F}$ at $2448^{\prime}$.

1300 - Ran SNL 7-pin temperature tool for log in TH-2 to compare with PTS tool and with previous log while pumping cold water.

\section{Aug 93}

0100 - Run Totco survey, hole is $2^{\circ}$ off vertical at $2508^{\prime}$.

$0440-$ BHT $312^{\circ} \mathrm{F}$ at $2528^{\prime}$

0700 - Replace wireline with new $5000^{\prime}$ line while drilling ahead.

$1240-\mathrm{BHT}$ is $320^{\circ} \mathrm{F}$ at $2557^{\prime}$.

2220 - At $2598^{\prime}$ pull back 32 stands and grease rods due to torque and vibrations.

\section{Aug 93}

$0100-\mathrm{BHT}$ is $315^{\circ} \mathrm{F}$ at $2608^{\prime}$. 
0610- Bit gone at 2598'. POOH.

0930 - Bit on carbides on outside gage. Will run a new special series 7 bit with Geosets on outside gage and lower diamond concentration. This bit design from Longyear bit engineer should improve gage protection and matrix stripping. Also rig up $20 \mathrm{ft}$ core barrel w/o top reamer shell.

1030- RIH while greasing with Husket grease loaded with Tork-ease.

1230- Back on bottom drilling.

29 Aug 93

Drilled ahead from $2690^{\prime}$ to $2795^{\prime}$.

\section{Aug 93}

Drilled ahead from $2795^{\prime}$ to $2930^{\prime}$.

2300 - Begin POOH with drillstring for flow tests.

\section{Aug 93}

0300 - RIH through $280^{\prime} \mathrm{N}$-rod with temperature logging tool. Log to bottom indicates relatively constant temperature, decreasing slightly below approximately $900^{\prime}$.

0545 - Have been airlifting well, it starts flowing on its own ( $25 \mathrm{gpm})$; will let it flow and heat at least until water cleans up.

0740 - Kill well to POOH with N-rods.

0820 - Pressurize wellhead to $100 \mathrm{psi}$.

0853 - Release pressure, well begins to flow through 2" James tube and stabilizes at about $60 \mathrm{gpm}$.

1022 - Throttle well back to about $45 \mathrm{gpm}$; since maximum flow rate is much less than that with 3" James tube, we will go back to the larger tube.

1147 - Pump cold water down well to kill it, $\mathrm{POOH}$ with logging tool, and pressurize wellhead. Change to 3" James tube.

1208 - Release pressure on wellhead, well begins to flow again at about $100 \mathrm{gpm}$.

1224 - James tube pressure transducer has calibration wires shorted, giving too high pressure.

1235 - Separate and dry calibration wires, pressure goes back to correct value.

1230 - Flow seems to be stabilizing at about $106 \mathrm{gpm}$. 
1305 - James tube transducer shorted again; clip calibration wires.

1508 - Throttled back well flow; stabilizes at about $88 \mathrm{gpm}$, run downhole log.

1826 - Throttled back well; flow is about $71 \mathrm{gpm}$, begin PTS log at 1840.

2025 - Throttled back to $50 \mathrm{gpm}$; take downhole data at 808', but not a full survey.

2050 - Open well to full flow with PTS tool hanging at 808', let flow stabilize and shut-in at 2122.

\section{Sept 93}

0520 - Injection water line is pressured up from power plant; begin pumping into well to determine maximum flow rate. Line temperature is $213^{\circ} \mathrm{F}$. Maximum flow rate is approximately 720 gpm, limited by pump (even with lower temperature water.) Logging tool (PTS) is not working and apparently has not been since before shut-in last night. Speculated cause of failure is high internal temperature, but tool cannot be easily or quickly repaired. Since there is no back-up tool, and since there is no meaningful test we can do without downhole instrumentation, injection tests are canceled. Will resume drilling at $2930^{\prime}$

0700 - RIH, grease rods, wash to bottom, and circulate hole.

1210 - Resume drilling at 2930 ' with same bit used on previous interval.

2210 - Drilling ahead at 2990'. Deviation survey $=1-1 / 4^{\circ}$.

\section{2-5 Sept 93}

Drilled from $3000^{\prime}$ to $3470^{\prime}$ with generally good rates of penetration $(\sim 10 \mathrm{ft} / \mathrm{hr})$. Downhole vibration problems have mostly ceased. Formation has few major open fractures except for vuggy/fractured zone at $3208^{\prime}$ which has fracture apertures $\sim 1 / 2^{\prime \prime}$. Bit changes at $3072^{\prime}$ and $3430^{\prime}$.

Have also spent these days examining and plotting data from three series of flow tests. In general, surface data (wellhead pressure and temperature, flash tank exit temperature, James tube pressure, magmeter flow rate, and weir box flow rate) appear good, although James tube pressure fluctuates enough to cause difficulty in deciding which value to use for flow rate calculations.

Downhole data shows considerable variation. Two different tools were used in the three tests, possibly with different transducers in the same tool for the second and third series of tests. Temperature and pressure apparently drift with time, with temperature changing as much as $10^{\circ} \mathrm{F}$ over 10-12 hours. Pressure during post-production shut-in tests also shows odd behavior - rising, then falling, then rising and falling again. Will attempt to resolve these anomalies before further testing.

1600 - Have POOH for bit change and rigged up SNL logging truck for temperature log. Frayed outer braid on wireline packs a rat's-nest into the cable guide at $\sim 2600^{\prime}$. Clear tangled wire, $\mathrm{POOH}$ with logging tool. Bad spot in wireline is too far from end to allow cutting off the 
frayed part and still reach bottom of hole at $4000^{\prime}$. Wire can be dressed to reduce the possibility of snagging, but we don't want to risk getting a downhole tangle, especially if logging through the packers.

\section{Sept 93}

0800 - Drilling ahead at 3510'. Deviation survey shows $1 / 4^{\circ}$.

\section{Sept 93}

0800 - Drilling ahead at $3650^{\prime}$. Some downhole torque, about to pull out of hole to grease rods and inspect bit.

1200 - Changing bit; bit in since $3450^{\prime}$ still has $\sim 60 \%$ life, but new one may finish hole.

1300- Set down on something at $268 \mathrm{ft}$ while RIH with new bit. Could not work through. POOH and inspect bit. It shows sign of riding on junk on outside gage. Bit is over gage, 3.925" rather than 3.895". PU new bit and RIH. It also set down at $268^{\prime}$ but wrenched through. Rig down for 2 hours for hydraulic repair.

1730- Back on bottom; drilling ahead at 3650' with low torque.

\section{Sept 93}

0700- Drilling ahead at 3730'.

2200 - Rate of penetration at 3799' has fallen drastically, to about $1 \mathrm{ft} / \mathrm{hr}$. $\mathrm{POOH}$ for bit change; bit is not badly worn, but matrix is not stripping. Core is much harder; previous core showed hardness $=5-6$ on scratch test, current core shows hardness $=7-8$

\section{Sept 93}

0230 - RIH with temperature tool for $\log$.

0530 - Log shows that bottom-hole temperature is less than $300^{\circ} \mathrm{F}$. RIH with new bit (series 10 ).

1730 - Drilling ahead at $3860^{\prime}$.

\section{Sept 93}

1200 - Have drilled to $4000^{\prime}$. Far West has tentatively decided not to drill deeper at this time. The principal decision is on what the test program should now be. Lengthy discussion has produced the following procedure: 1) run in hole with SNL temperature tool through drill pipe with bit at 3500' (hoping that the bit will act as a quasi-packer) and let tool sit at bottom to see if it warms up; 2) $\log$ out of hole, attach SNL pressure-temperature tool to bottom of temp tool and do comparison $\log ; 3$ ) trip out of hole and start well flow for production test, use commercial logging company for PTS surveys while flowing and shutin; 4) kill well and do full-hole injection with PTS; 5) based on results of injection, consider packer tests. 
1830 - Temperature tool is at bottom; temperature is $147.8^{\circ} \mathrm{C}\left(298^{\circ} \mathrm{F}\right)$.

\section{Sept 93}

0630 - Tool has been hanging at $3990^{\prime}$ for 12 hours, temperature is $146.35^{\circ} \mathrm{C}\left(295.4^{\circ} \mathrm{F}\right) \mathrm{Log}$ up hole, temperatures do not vary much between logs until above production zone at $815^{\prime}$. Begin pulling out of hole with drill rod so that we can air-lift hole and start flow.

1300 - Did not need to air-lift, just pressurized wellhead. After third pressure, well flow started. Can probably start well without air-lift now because cooler drilling fluid goes into the formation at a deeper zone than at earlier tests and the top of the hole stays hotter.

1500 - RIH with SNL temperature tool for flowing log

1600 - Tool hangs up on something at $\sim 2700^{\prime}$, try to come out of hole. Cable or tool stuck at $1700^{\prime}$. Kill well, allow it to cool, and remove top of lubricator. Wireline is badly tangled inside and so cannot pull through top pack-off (i.e., knot formed at about 1000' depth when line went slack because of set-down.) Untangle wireline (knot area is seriously frayed) and pull the rest of the way out of the hole.

1930 - Release pressure on wellhead, flow begins. Cut off cable head, spool out wireline to bad spot, and cut to re-head. PT tool has bad temperature transducer (RTD). Waiting for loggers; continue to flow well.

2315 - James tube pressure goes down almost 1 psi when crew uses steam-cleaning line off of flow tee.

\section{Sept 93}

0515 - Loggers arrive, begin rigging up. Well flow rate and James tube pressure are down slightly.

0930 - After several problems with logging truck, go in hole with PTS tool for production log. Tool hits same obstruction that stopped SNL log yesterday. Pull up to $805^{\prime}$ and shut in well.

1500 - POOH with PTS tool. RIH with drillpipe, feel no obstruction at $2700^{\prime}$.

1830 - Drill pipe hanging at 2720', RIH with SNL temperature tool and PT memory tool. Tools hang up at $3200^{\prime}$, cannot get deeper. $\mathrm{POOH}$, memory tool has no data.

2330 - Plan to RIH with rest of drill pipe, core about 1' (capturing any cave that has fallen into the wellbore), $\mathrm{POOH}$ with drill pipe, and try another temperature log.

\section{Sept 93}

0600- Rigging up for temperature log with SNL tool; memory tool not working (batteries). 
0830 - Tool goes to bottom of hole with no interference; will hang at bottom for $1 / 2$ hour and $\mathrm{POOH}$.

1000 - Logging company rigging up for static PTS log; will pull up into lubricator afterward and start injection with new pump, supposedly capable of $100 \mathrm{psi} / 2000 \mathrm{gpm}$.

1240 - Begin taking data for injection test; PTS tool is out of lubricator, cooling

1248 - Injection starts; pump can only deliver $\sim 900 \mathrm{gpm}$. Pressure at pump is $150 \mathrm{psi}$ (60 psi line pressure from power plant), but only $60 \mathrm{psi}$ at wellhead. This implies 90 psi pressure loss in supply line from pump to wellhead, which seems high.

1445 - Begin PTS log, flow has stabilized at $\sim 920 \mathrm{gpm} / 58$ psi wellhead pressure. Log to bottom and back up.

1745 - Injection ends

1800 - Pick up packer. Will set it at $1060^{\prime}$ and take temperature recovery logs. RIH with packer on H-rod.

2130 - Packer is set but we cannot retrieve standing valve. Wireline overshot is either not engaging valve stem, or is releasing it. Examine overshot and call packer manufacturer; overshot appears to be right.

14 Sept 93

0030 - Decide to $\mathrm{POOH}$; release packer by turning drill pipe.

0130 - Packer has crossover to N-rod thread (because we first ran it on $\mathrm{N}$ ) then N-to-H. N-to-H crossover ID is too small to pass the overshot.

0400 - Get new crossover; RIH again with packer and set at 1060'.

0500 - Retrieve standing valve with overshot.

0752 - RIH with loggers' PTS tool (really a PT tool; spinner removed to get through packer. Log down and up.

1230 - Repeat PT log through packer. Temperatures below packer are identical with first log. Rig up to pump cold water through packer.

1614 - Start injecting cold water at $\sim 460 \mathrm{gpm} / 90 \mathrm{psi}$ wellhead pressure. Log to bottom and back to $2150^{\prime}$. Flow stabilizes at $440 \mathrm{gpm}$.

1735 - Stop injection, log pressure/temperature at $2150^{\prime}$.

1900 - POOH with logging tool; POOH with packer. Will pick up second packer, RIH to 2450', and set packer. 
2330 - Inflate packer, but it doesn't hold pressure. Try to re-inflate, with no success.

\section{Sept 93}

0030 - Begin POOH with packer; will RIH with other packer.

0430 - New packer set, holds pressure, rig up for static log through packer to TD.

0628 - Begin static log through packer; temperature below packer has hardly changed since previous logs.

1230 - Second static log through packer; temperatures below packer have not changed since previous static log. Rig up to inject through packer.

1344 - Start injecting through packer with big pump; flow rate is approximately $280 \mathrm{gpm}$ with a wellhead pressure of $110 \mathrm{psi}$. This compares with injection through the packer at 1060', when flow was $450 \mathrm{gpm}$ at 90 psi wellhead pressure. It appears that, although some of the difference could be caused by friction loss in the longer pipe, the formation must be considerably less permeable below $2500^{\prime}$. Try to do traverse downhole, but logging tool cannot get below $2700^{\prime}$. It first appears that this could be flow related, but we later find that the tool will not pass this zone even after flow is shut-in.

1600 - POOH with drill pipe and packer. Rig up for flow test, run primarily to test SNL memory tool at production shut-in.

2000 - Release pressure on wellhead, flow begins

2115 - Lower PT memory tool to 800'; will leave it there for 5 hours.

\section{Sept 93}

0230 - Retrieve memory tool; it has successfully taken data. Make wiper trip to bottom with drill pipe, driller can feel obstruction at 2700' where logging tool stopped. Begin POOH with drill pipe, laying down $10^{\prime}$ rods. Will release rig when pipe is laid down. 


\begin{abstract}
APPENDIX B
The following appendix contains the daily drilling records, including detailed information about drilling fluids, drill bits, lithology, and other activities conducted each day. These reports were prepared and distributed each day to Sandia staff and management, DOE program managers, Far West Capital, and other interested researchers. The reports were compiled primarily by the Sandia on-site project leaders, with valuable input from Desert Drilling Fluids and Longyear field engineers, as well as personnel from the UNLV Division of Earth Sciences.
\end{abstract}


DAILY DRILLING REPORT - 07/21/93

STEAMBOAT HILLS EXPLORATORY SLIMHOLE

Time of report - 0800

Well number - SNLG 87-29| Location - SE 1/4, SE 1/4, Section 29, T18N, R20E, Washoe County, NV

Days since spud - 1|Depth today - 2' | Hole advance last $24 \mathrm{hr}-2^{\prime} \mid$ Core recovered - $\mathrm{n} / \mathrm{a}$

BITS -- Now drilling 12-1/4" hole | Rotary speed - $\quad \mathrm{rpm}$; WOB - $\quad \mathrm{lb}$; Rate of Penetration - $\mathrm{ft} / \mathrm{hr}$

Bit number | Type | Depth in, KB | Depth out; KB | Footage | Hours $12-1 / 4^{\prime \prime}$ tri-cone
$10^{\prime}$
$12^{\prime}$
2
2

1

Drilling fluid - air

Flow rate - gal $/ \mathrm{min} \mid$ Pressure - $\mathrm{psi} \mid$ Returns temp - ${ }^{\circ} \mathrm{F} \mid$

$\mathrm{Wt}$ - $\mathrm{lb} / \mathrm{gal}|\mathrm{Vis}-\mathrm{sec}| \mathrm{PV}-\mathrm{cP}\left|\mathrm{YP}-\mathrm{lb} / 100 \mathrm{ft}^{2}\right| \mathrm{pH}-$

Lost circulation -

Lithology of today's core : $\mathbf{n} / \mathbf{a}$

Summary of events last 24 hours:

Completed rigging up and spudded 12-1/4" hole approximately $3^{\prime}$ for mud riser. Cemented in 9-5/8" casing, WOC, and welded riser to $8^{\prime}$ above ground for returns and flow line.

Report by: John Finger

B-2 


\section{DAILY DRILLING REPORT - 07/22/93 \\ STEAMBOAT HILLS EXPLORATORY SLIMHOLE \\ Time of report - 0800}

Well number - SNLG 87-29 | Location - SE 1/4, SE 1/4, Section 29, T18N, R20E, Washoe County, NV

Days since spud - $2 \mid$ Depth today - $121^{\prime} \mid$ Hole advance last $24 \mathrm{hr}-119^{\prime} \mid$ Core recovered - $115^{\prime}$

Last casing - 9-5/8" riser @ 3'

BITS -- Now drilling 3.89" hole | Rotary speed - $\quad \mathrm{rpm}$; WOB - $\quad \mathrm{lb}$; Rate of Penetration - $\mathrm{ft} / \mathrm{hr}$

Bit number | Type | Depth in, KB | Depth out, KB | Footage | Hours

1 12-1/4" tri-cone $\quad 10^{\prime} \quad 12^{\prime} \quad 12$

2 HQ impreg $12^{\prime}$

Drilling fluid - water, bentonite, polymer

Flow rate - $30 \mathrm{gal} / \mathrm{min} \mid$ Pressure - psi | Returns temp - $90^{\circ} \mathrm{F} \mid$

$\mathrm{Wt}-8.5 \mathrm{lb} / \mathrm{gal}|\mathrm{Vis}-33 \mathrm{sec}| \mathrm{PV}-10 \mathrm{cP}\left|\mathrm{YP}-4 \mathrm{lb} / 100 \mathrm{ft}^{2}\right| \mathrm{pH}-8.0$

Lost circulation - generally minor, up to $20 \%$

Lithology of today's core : not yet logged

Summary of events last 24 hours:

Picked up HQ core string and drilled approximately 119'. Top 25-30 feet were very hard, but softer rock below that, including significant amounts of clayey, highly altered volcanics.

Report by: John Finger 
DAILY DRILLING REPORT - 07/23/93

STEAMBOAT HILLS EXPLORATORY SLIMHOLE

Time of report -0800

Well number - SNLG 87-29 | Location - SE 1/4, SE 1/4, Section 29, T18N, R20E, Washoe County, NV

Days since spud - 3| Depth today - 176 $\mid$ Hole advance last $24 \mathrm{hr}-55^{\prime} \mid$ Core recovered - $55^{\prime}$

Last casing - 9-5/8" riser @ $3^{\prime}$

BITS -- Now reaming 8.5" hole | Rotary speed - $\mathrm{rpm}$; WOB - $\quad \mathrm{lb}$; Rate of Penetration - $\mathrm{ft} / \mathrm{hr}$

Bit number | Type | Depth in, KB | Depth out, KB | Footage | Hours

$1 \quad 12-1 / 4^{\prime \prime}$ tri-cone $\quad 10^{\prime} \quad 12^{\prime} \quad 16$

2 HQ impreg $\quad 12^{\prime} \quad 172^{\prime} \quad 160 \quad 16$

$\begin{array}{llllll}3 & 8-1 / 2^{\prime \prime} \text { tri-cone } & 1^{\prime} & 176^{\prime} & 164 & 12\end{array}$

Drilling fluid - water, bentonite, polymer

Flow rate - $70 \mathrm{gal} / \mathrm{min} \mid$ Pressure - psi | Returns temp - $90^{\circ} \mathrm{F}$ |

$\mathrm{Wt}-8.5 \mathrm{lb} / \mathrm{gal}|\mathrm{Vis}-33 \mathrm{sec}| \mathrm{PV}-10 \mathrm{cP}\left|\mathrm{YP}-4 \mathrm{lb} / 100 \mathrm{ft}^{2}\right| \mathrm{pH}-8.0$

Lost circulation -

Lithology of today's core : not yet logged

Summary of events last 24 hours:

Finished coring HQ to 172 ' at approximately 1200 yesterday. Picked up 8-1/2" roller-cone bit to ream HQ hole Reaming very slow at first because of hard surface formation and little weight on bit, but picked up at deeper part of hole. Drilled approximately 4' deeper with roller bit than cored so that top of casing would have the correct height for cementing. Made wiper trip and circulated hole in preparation for running 7" casing.

Report by: John Finger 
DAILY DRILLING REPORT - 07/2493

STEAMBOAT HILLS EXPLORATORY SLIMHOLE

Time of report - 0800

Well number - SNLG 87-29 | Location - SE 1/4, SE 1/4, Section 29, T18N, R20E, Washoe County, NV

Days since spud - 4 | Depth today - 176' | Hole advance last $24 \mathrm{hr}-0^{\prime} \mid$ Core recovered - n/a

Last casing - 7", 20 lb/ft @ 175'

BITS -- Now drilling $\mathbf{x x x}^{\prime \prime}$ hole | Rotary speed - $\mathrm{rpm}$; WOB - $\quad \mathrm{lb}$; Rate of Penetration - $\mathrm{ft} / \mathrm{hr}$

Bit number | Type | Depth in, KB | Depth out, KB | Footage | Hours

1

12-1/4" tri-cone

HQ impreg

$10^{\prime}$

$8-1 / 2^{\prime \prime}$ tri-cone

$12^{\prime}$

$12^{\prime}$

$172^{\prime}$

$176^{\prime}$

$160 \quad 16$

$164 \quad 12$

Drilling fluid - water, bentonite, polymer

Flow rate - xx gal/min | Pressure - psi $\mid$ Returns temp - xxㅇ

$\mathrm{Wt}-8.5 \mathrm{lb} / \mathrm{gal}|\mathrm{Vis}-33 \mathrm{sec}| \mathrm{PV}-10 \mathrm{cP}\left|\mathrm{YP}-4 \mathrm{lb} / 100 \mathrm{ft}^{2}\right| \mathrm{pH}-8.0$

Lost circulation -

Lithology of today's core : $\mathbf{n} / \mathbf{a}$

Summary of events last 24 hours:

Ran 4 joints 7"/20lb casing, with float shoe at bottom and float collar at top of first joint. Cemented with $49 \mathrm{cu}$. ft. of Portland cement with friction reducer and $35 \%$ silica flour. Full cement returns to surface, displaced cement with water. Cement away at 1530, WOC until 0400 and begin welding wellhead. Begin nippling up BOP at 0730 .

Report by: John Finger 
DAILY DRILLING REPORT - 07/25/93

STEAMBOAT HILLS EXPLORATORY SLIMHOLE

Time of report - 0800

Well number - SNLG 87-29 | Location - SE 1/4, SE 1/4, Section 29, T18N, R20E, Washoe County, NV

Days since spud - $5 \mid$ Depth today - 212' | Hole advance last $24 \mathrm{hr}-36^{\prime} \mid$ Core recovered - 36'

Last casing - 7", $20 \mathrm{lb} / \mathrm{ft} @ 175^{\prime}$

BITS -- Now drilling 6-1/4" hole | Rotary speed - $300 \mathrm{rpm}$; WOB - 3Klb; Rate of Penetration - $\mathrm{ft} / \mathrm{hr}$

Bit number | Type | Depth in, KB | Depth out, KB | Footage | Hours

$1 \quad 12-1 / 4^{\prime \prime}$ tri-cone $\quad 10^{\prime} \quad 12^{\prime} \quad 16$

2 HQ impreg $\quad 12^{\prime} \quad 172^{\prime} \quad 160 \quad 16$

$3 \quad 8-1 / 2^{\prime \prime}$ tri-cone $\quad 12^{\prime} \quad 176^{\prime} \quad 164 \quad 12$

4 6-1/4" impreg 110' (cement)

Drilling fluid - water, bentonite, polymer

Flow rate $-40 \mathrm{gal} / \mathrm{min} \mid$ Pressure - psi $\mid$ Returns temp - $100^{\circ} \mathrm{F} \mid$

$\mathrm{Wt}-8.5 \mathrm{lb} / \mathrm{gal}|\mathrm{Vis}-33 \mathrm{sec}| \mathrm{PV}-10 \mathrm{cP}\left|\mathrm{YP}-4 \mathrm{lb} / 100 \mathrm{ft}^{2}\right| \mathrm{pH}-8.0$

Lost circulation - intermittent

Lithology of today's core : Not yet logged

Summary of events last 24 hours:

Finish nippling up BOP, tested accumulators, and rams. Blind and pipe rams each held 500 psi for 15 minutes. Minor leak around kill line nipple welded. Tests witnessed and approved by Dick Whiting, Nevada Department of Minerals. Picked up 5-1/2" core rods and 6-1/4" bit, RIH and tagged top of cement at 110'. Drilled through casing shoe at 2230 , coring ahead since then.

Report by: John Finger 


\section{DAILY DRILLING REPORT - 07/26/93 \\ STEAMBOAT HILLS EXPLORATORY SLIMHOLE \\ Time of report - 0800}

Well number - SNLG 87-29.| Location - SE 1/4, SE 1/4, Section 29, T18N, R20E, Washoe County, NV

Days since spud - 6 | Depth today - 295'| Hole advance last $24 \mathrm{hr}-83^{\prime} \mid$ Core recovered - 83'

Last casing - 7", $20 \mathrm{lb} / \mathrm{ft} @ 175^{\prime}$

BITS -- Now drilling 6-1/4" hole | Rotary speed - $300 \mathrm{rpm}$; WOB - 3Klb; Rate of Penetration - 5-6 ft/hr

\begin{tabular}{c|ccc|c|c} 
Bit number | & Type & Depth in, KB | & Depth out, KB & Footage | Hours \\
1 & $12-1 / 4^{\prime \prime}$ tri-cone & $10^{\prime}$ & $12^{\prime}$ & 2 & 2 \\
2 & HQ impreg & $12^{\prime}$ & $172^{\prime}$ & 160 & 16 \\
3 & $8-1 / 2^{\prime \prime}$ tri-cone & $12^{\prime}$ & $176^{\prime}$ & 164 & 12 \\
4 & $6-1 / 4^{\prime \prime}$ impreg & $110^{\prime}$ (cement) & $225^{\prime}$ & 115 & \\
5 & $6-1 / 4^{\prime \prime}$ impreg & $225^{\prime}$ & & &
\end{tabular}

Drilling fluid - water, bentonite, polymer, MagmaFiber and paper LCM

Flow rate $-25 \mathrm{gal} / \mathrm{min} \mid$ Pressure - psi | Returns temp - $130^{\circ} \mathrm{F} \mid$

$\mathrm{Wt}-8.6 \mathrm{lb} / \mathrm{gal}|\mathrm{Vis}-36 \mathrm{sec}| \mathrm{PV}-12 \mathrm{cP}\left|\mathrm{YP}-6 \mathrm{lb} / 100 \mathrm{ft}^{2}\right| \mathrm{pH}-8.0$

Lost circulation - intermittent

Lithology of today's core : Not yet logged

Summary of events last 24 hours:

Continue coring 6-1/4" hole $\times 4$ " core. Entered top of granodiorite at approximately $225^{\prime}$. This formation is fairly hard but drills reasonably well at 5 to $6 \mathrm{ft} / \mathrm{hr}$. Lost circulation varies from total to none, but has mostly been less than $25 \%$. Lost some time last night when wireline broke, apparently because the core tube snagged on a protrusion inside one of the rods. Tripped rods and laid down bad one.

Report by: John Finger 


\section{DAILY DRILLING REPORT - 07/27/93 \\ STEAMBOAT HILLS EXPLORATORY SLIMHOLE \\ Time of report - 0800}

\section{Well number - SNLG 87-29 | Location - SE 1/4, SE 1/4, Section 29, T18N, R20E, Washoe County, NV}

Days since spud - $7 \mid$ Depth today - 415' | Hole advance last $24 \mathrm{hr}-120^{\prime} \mid$ Core recovered $-120^{\prime}$

Last casing - 7", $20 \mathrm{lb} / \mathrm{ft} @ 175^{\prime}$

BITS -- Now drilling 6-1/4" hole | Rotary speed - $300 \mathrm{rpm}$; WOB - 3Klb; Rate of Penetration - 5-6 ft/hr

Bit number | Type | Depth in, KB | Depth out, KB | Footage | Hours

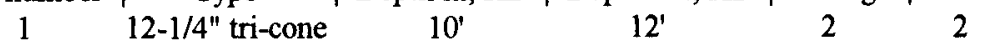

2 HQ impreg $\quad 12^{\prime} \quad 172^{\prime} \quad 160 \cdot 16$

$3 \quad 8-1 / 2^{\prime \prime}$ tri-cone $12^{\prime} \quad 176^{\prime} \quad 164 \quad 12$

4 6-1/4" impreg $110^{\prime}$ (cement) 225' 115

5 6-1/4" impreg 225'

Drilling fluid - water, bentonite, polymer, MagmaFiber and paper LCM

Flow rate - $25 \mathrm{gal} / \mathrm{min}$ | Pressure - psi | Returns temp - $160^{\circ} \mathrm{F}$ |

$\mathrm{Wt}-8.6 \mathrm{lb} / \mathrm{gal}|\mathrm{Vis}-31 \mathrm{sec}| \mathrm{PV}-7 \mathrm{cP}\left|\mathrm{YP}-1 \mathrm{lb} / 100 \mathrm{ft}^{2}\right| \mathrm{pH}-8.0$

Lost circulation - slight, hole is probably making fluid

Lithology of core to date:

surf- $43^{\prime}$ Siliceous sinter, siliceous cemented, laminated fractured breccia

43 - 45' Hydrothermally altered, clay rich, punky, siliceous breccia

45 - 48' Non - clay

48 - 56' Black matrix, siliceous breccia, hydrothermally altered in places

56 - 61' Plucked clasts, black-gray breccia

61 - 73' Clay-rich, green, gray-green to black layers

73 - 91' Becomes granular, intercalated with clay and altered volcanic rock

91 - 106' Heavily altered soft clay

106 - 112' Pale green, highly altered volcanic rock, clay, remnant phenocrysts apparent

112 - 114' Less clayey, still altered

114 - $120^{\prime}$ Visible $1 \mathrm{~cm}$ pyrite crystals, very competent, no clay

120 - $125^{\prime}$ Pale green epidote altered lahar with $1 \mathrm{~cm}$ pyrite and quartz lining veins

125 - $140^{\prime}$ Darker green, less alteration, $1 \mathrm{~cm}$ pyrite crystals and stibnite needles on fractures

140 - 152' Vugs, partially filled with $\mathrm{SiO} 2$, appear, no pyrite or stibnite

152 - 163' $1 \mathrm{~mm}$ pyrite crystals, brecciated volcanics with red mineral filling veins and fractures

163 - 167 Rapidly becomes clayey \& non-competent, clay is matrix, phenocrysts altered, olive-drab to pale green

$167-170^{\prime}$ Vuggy, hydrothermally altered, rounded clasts, $1 \mathrm{~mm}$ pyrite and $\mathrm{SiO} 2$ in veins, also red mineral vein fillings

$170-173^{\prime} \quad$ Not cored

173 - $187^{\prime}$ Altered volcanics, fine grained, light gray, volcanic lahar, SiO2 vein filling, vuggy, trending to less vuggy with no mineralization

187 - 194' $1 \mathrm{~cm}$ wide red vein along fracture, vertical to sub-horizontal

194 - 196' Red veins disappear, $1 \mathrm{~mm}$ pyrite returns

196 - $206^{\prime}$ Increasingly clay-rich with pyrite, fine-grained

206 - 216' Clay

216 - $220^{\prime}$ Altered volcanic breccia or dry clay with pyrite mineralization

220 - 223' Larger breccia clasts, vuggy, $\mathrm{SiO} 2$ filled fractures, light gray to pale green

223 - 225' Pale purple, light green volcanic breccia, no clay, very minor mineralization

Summary of events last 24 hours:

Continue coring 6-1/4" hole $\times 4$ " core. Continued drilling granodiorite since yesterday with almost complete core recovery. Returns temperature increasing to a peak $\sim 165^{\circ} \mathrm{F}$. Hole is probably producing some fluid into the flow stream - viscosity is down, chlorides are up, and flow instrumentation shows excess returns fairly regularly. 


\section{DAILY DRILLING REPORT - 07/28/93 \\ STEAMBOAT HILLS EXPLORATORY SLIMHOLE \\ Time of report -0800}

Well number - SNLG 87-29 | Location - SE 1/4, SE 1/4, Section 29, T18N, R20E, Washoe County, NV

Days since spud - 8| Depth today - 495' | Hole advance last $24 \mathrm{hr}-80^{\prime} \mid$ Core recovered - 80'

Last casing - 7", $20 \mathrm{lb} / \mathrm{ft}$ (a) 175'

BITS -- Now drilling 6-1/4" hole | Rotary speed - $300 \mathrm{rpm}$; WOB - 3Klb; Rate of Penetration - 5-6 ft/hr
\begin{tabular}{|c|c|ccc|c} 
Bit number & Type & Depth in, KB | Depth out, KB | Footage | Hours \\
1 & $12-1 / 4^{\prime \prime}$ tri-cone & $10^{\prime}$ & $12^{\prime}$ & 2 & 2 \\
2 & HQ impreg & $12^{\prime}$ & $172^{\prime}$ & 160 & 16 \\
3 & $8-1 / 2^{\prime \prime}$ tri-cone & $12^{\prime}$ & $176^{\prime}$ & 164 & 12 \\
4 & $6-1 / 4^{\prime \prime}$ impreg & $110^{\prime}$ (cement) & $225^{\prime}$ & 115 & \\
5 & $6-1 / 4^{\prime \prime}$ impreg & $225^{\prime}$ & $462^{\prime}$ & 237 & \\
\hline
\end{tabular}

Drilling fluid - water, bentonite, polymer, MagmaFiber and paper LCM

Flow rate $-25 \mathrm{gal} / \mathrm{min} \mid$ Pressure - psi | Returns temp - $145^{\circ} \mathrm{F}$ |

$\mathrm{Wt}-8.6 \mathrm{lb} / \mathrm{gal}|\mathrm{Vis}-35 \mathrm{sec}| \mathrm{PV}-13 \mathrm{cP}\left|\mathrm{YP}-4 \mathrm{lb} / 100 \mathrm{ft}^{2}\right| \mathrm{pH}-7.5$

Lost circulation - slight

Lithology of core logged since yesterday:

225 - 226' $2 \mathrm{~cm}$ quartz-filled veins, vuggy, minor mineralization, fresh looking

226 - 230' Brecciated gradational contact between volcanic and granodiorite, pale green to gray mediumgrained volcanic adjacent to pinkish-red medium-grained granodiorite, $2 \mathrm{~cm}$ near-vertical quartz veins are $90 \%$ filled, no recent hydrothermal alteration

230 - 414' Below 230' formation remains granodiorite, with the following features at the given depth

233' Pinkish-gray equigranular, medium-grained ; $2-3 \mathrm{~cm}$ filled quartz veins:

$235^{\prime} 1 \mathrm{~cm}$ filled quartz veins, minor fractures @ $30^{\circ}$ to vertical filled with red mineral

$240^{\prime}$ Decreasing quartz and red veins

244' Massive 2-3 cm quartz veins

$254^{\prime}$ Increasing irregularly spaced $1 \mathrm{~mm}$ fractures with quartz@ $70^{\circ}$ from vertical

260' Veins @ $45^{\circ}$ from vertical

272' Massive $1 \mathrm{~cm}$ quartz veins

$275^{\prime} 1 \mathrm{~mm}$ quartz veins

$282^{\prime}$ Intersecting fracture sets, near vertical and $45^{\circ}$, vugs or dissolution cavities near intersection

293' 1-2 mm filled veins with minor quartz

$303^{\prime}$ Veins, red, black, and quartz

306' Massive quartz veins @ $45^{\circ}$

309' No quartz veins this interval

313' Minor fractures with erosion in fractures, some quartz filling

$316^{\prime}$ Fractures at $30^{\circ}$ to vertical, 1 large quartz-filled with red mineral zoning

$321^{\prime}$ Less pink, now medium gray-green

$327^{\prime}$ Vertical to sub-vertical green veins

331' $1 \mathrm{~mm}$ near-vertical veins with green mineralization

$355^{\prime}$ Occasional fractues, possibly open, with quartz filling

$369^{\prime}$ Spiderweb veining, dark color, occasional open fractures at $45^{\circ}$

$383^{\prime}$ Noticeable $5 \mathrm{~cm}$ xenolith

$385^{\prime}$ Natural fractues at $20^{\circ}$ to vertical with associated chlorite mineralization

$390^{\prime}$ Quartz veining at $45^{\circ}$

394' Spiderweb veins continue, no quartz veining

$396^{\prime} \quad 1-2 \mathrm{~cm}$ multi-generational quartz vein at $45^{\circ}$

399' Extensive fracture with pyrite-sulfide mineralization (1' interval)

406 ' Natural fracture (1')

Summary of events last 24 hours:

Continue coring 6-1/4" hole $\times 4$ " core. Continued drilling granodiorite since yesterday with almost complete core recovery. Bit change at $462^{\prime}$. [ Report by: John Finger 
DAILY DRILLING REPORT - 07/29/93

STEAMBOAT HILLS EXPLORATORY SLIMHOLE

Time of report - 0800

Well number - SNLG 87-29 | Location - SE 1/4, SE 1/4, Section 29, T18N, R20E, Washoe County, NV

Days since spud - 9| Depth today - 510' $\mid$ Hole advance last $24 \mathrm{hr}-15^{\prime} \mid$ Core recovered - 15'

Last casing - 7", 20 lb/ft @ 175'

BITS -- Now drilling 6-1/4" hole | Rotary speed - $300 \mathrm{rpm}$; WOB - 3Klb; Rate of Penetration - 5-6 ft/hr

Bit number | Type | Depth in, KB | Depth out, KB | Footage | Hours

$\begin{array}{lccccc}1 & 12-1 / 4^{\prime \prime} \text { tri-cone } & 10^{\prime} & 12^{\prime} & 2 & 2 \\ 2 & \text { HQ impreg } & 12^{\prime} & 172^{\prime} & 160 & 16 \\ 3 & 8-1 / 2^{\prime \prime} \text { tri-cone } & 12^{\prime} & 176^{\prime} & 164 & 12 \\ 4 & 6-1 / 4^{\prime \prime} \text { impreg } & 110^{\prime} \text { (cement) } & 225^{\prime} & 115 & \\ 5 & 6-1 / 4^{\prime \prime} \text { impreg } & 225^{\prime} & 462^{\prime} & 237 & \\ 6 & 6-1 / 4^{\prime \prime} \text { impreg } & 462^{\prime} & & & \end{array}$.

Drilling fluid - water, bentonite, polymer; MagmaFiber and paper LCM

Flow rate - $25 \mathrm{gal} / \mathrm{min} \mid$ Pressure - psi $\mid$ Returns temp - $155^{\circ} \mathrm{F}$

$\mathrm{Wt}-8.6 \mathrm{lb} / \mathrm{gal}|\mathrm{Vis}-33 \mathrm{sec}| \mathrm{PV}-8 \mathrm{cP}\left|\mathrm{YP}-4 \mathrm{lb} / 100 \mathrm{ft}^{2}\right| \mathrm{pH}-12$ (cement returns)

Lost circulation - mostly

Lithology of core logged since yesterday: [Summary - detailed log available]

Core from $414^{\prime}$ to $506^{\prime}$ is all granodiorite, generally with spiderweb veining, $1 \mathrm{~mm}$ to $1 \mathrm{~cm}$ calcite-filled fractures, most fractures at about $45^{\circ}$, some red and green mineralization. Unusual features as described below -

$424^{\prime}$ More frequent $5 \mathrm{~mm}$ calcite filled fractures at $45^{\circ}$ on $1^{\prime}$ to $1.5^{\prime}$ spacing

434 ' No major fractures, breaks have minor reaction to $\mathrm{HCl}$, disseminated sulfite mineralization

$438^{\prime}-440^{\prime}$ Slightly pale green, slight hydrothermal alteration, epidote-chlorite alteration of phenocrysts,

significant spiderweb veining, $45^{\circ}$ fracture with $1 \mathrm{~mm}$ calcite veins

$447^{\prime}$ Near vertical $1 \mathrm{~mm}$ calcite fracture with some hydrothermal alteration, $5 \mathrm{~cm}$ xenolith in fracture

453' Begin disseminated pyrite throughout

$467^{\prime}$ Slightly more altered granodiorite, $45^{\circ}$ veins with green mineral filling

$480^{\prime}-490^{\prime}$ Massive (>10 cm) calcite vein, $30^{\circ}$ to near vertical, epidote rim, granodiorite relatively unaltered

$495^{\prime}$ - 498' Core has rougher, sticky surface, clayey, zone ends at $45^{\circ}$ fracture

505 ' Return of $10 \mathrm{~cm}$ calcite vein described above

Summary of events last 24 hours:

Continued coring 6-1/4" hole x 4" core. Complete loss of returns at approx $0915\left(\sim 500^{\prime}\right)$. Lost 25-30 gpm for about 3 hours and then a combination of lost circulation materials sealed fracture. Drilled ahead until about 1400 and lost returns again. Repeated attempts to plug fracture with LCM were futile. Recovered core shows a massive $(>3 ")$ calcite-filled fracture. Rigged up to mix cement; pumped 10 sacks cement through open-ended $\mathrm{H}$-rod at the fracture and led it with a slug of cottonseed hulls. WOC until 0200, it appeared firm, filled up hole with fluid and it retained the fluid. Tagged cement $\left(\sim 480^{\prime}\right)$ with drillpipe, $\mathrm{POOH}$ with $\mathrm{H}$-rod, $\mathrm{RIH}$ with $5-1 / 2^{\prime \prime}$ and resume drilling $6-1 / 4 "$ hole. Target is to reach approximately $520^{\prime}$, which will allow running televiewer past fracture and will give enough hole to set casing at $500^{\prime}$ (required to drill to $5000^{\prime}$.)

Report by: John Finger 


\section{DAILY DRILLING REPORT - 07/30/93 \\ STEAMBOAT HILLS EXPLORATORY SLIMHOLE \\ Time of report -0800}

Well number - SNLG 87-29|Location - SE 1/4, SE 1/4, Section 29, T18N, R20E, Washoe County, NV

Days since spud - $10 \mid$ Depth today - 525' $\mid$ Hole advance last $24 \mathrm{hr}-15^{\prime} \mid$ Core recovered - $15^{\prime}$

Last casing - 4-1/2", $11.5 \mathrm{lb} / \mathrm{ft} @ 524^{\prime}$

BITS -- Now drilling 6-1/4" hole | Rotary speed - $300 \mathrm{rpm}$; WOB - 3Klb; Rate of Penetration - 5-6 ft/hr

\begin{tabular}{c|c|c|cc|c} 
Bit number & Type & Depth in, KB | & Depth out, KB | Footage | Hours \\
1 & $12-1 / 4^{\prime \prime}$ tri-cone & $10^{\prime}$ & $12^{\prime}$ & 2 & 2 \\
2 & HQ impreg & $12^{\prime}$ & $172^{\prime}$ & 160 & 16 \\
3 & $8-1 / 2^{\prime \prime}$ tri-cone & $12^{\prime}$ & $176^{\prime}$ & 164 & 12 \\
4 & $6-1 / 4^{\prime \prime}$ impreg & $110^{\prime}$ (cement) & $225^{\prime}$ & 115 & \\
5 & $6-1 / 4^{\prime \prime}$ impreg & $225^{\prime}$ & $462^{\prime}$ & 237 & \\
6 & $6-1 / 4^{\prime \prime}$ impreg & $462^{\prime}$ & $525^{\prime}$ & 63
\end{tabular}

Drilling fluid - water, bentonite, polymer; MagmaFiber and paper LCM

Flow rate $-25 \mathrm{gal} / \mathrm{min} \mid$ Pressure - $\mathrm{psi} \mid$ Returns temp - $155^{\circ} \mathrm{F} \mid$

$\mathrm{Wt}-8.5 \mathrm{lb} / \mathrm{gal}|\mathrm{Vis}-35 \mathrm{sec}| \mathrm{PV}-9 \mathrm{cP}\left|\mathrm{YP}-1 \mathrm{lb} / 100 \mathrm{ft}^{2}\right| \mathrm{pH}-9.0$

Lost circulation - minor

Lithology of core logged since yesterday: [Summary - detailed log available]

Core from $510^{\prime}$ to $525^{\prime}$ is still granodiorite, containing the end of the same massive calcite vein described yesterday.

Summary of events last 24 hours:

Continued coring 6-1/4" hole x 4" core. Reached target of 525'. Ran temperature log through drill pipe and bit; laid down 5-1/2" drill pipe. Ran another temperature log in open hole; latter log was much more erratic, partially because of pumping across the riser, which caused the hole to take some fluid. Maximum temperature in second $\log$ was $132^{\circ} \mathrm{C}$ at bottom. RIH with $\mathrm{H}$-rod and circulate to cool and clean hole; rig up for televiewer run.

Televiewer successful; showed numerous fractures mostly dipping southwest, although some were in the opposite orientation. Rigged up and ran casing, pumped $125 \mathrm{cu} \mathrm{ft}$ (100\% excess) cement and did not get returns, although the water lead did appear to return (cement probably got back near surface but fell away.) Will do temperature log to try and locate top of cement.

Report by: John Finger 


\section{DAILY DRILLING REPORT - 07/31/93 \\ STEAMBOAT HILLS EXPLORATORY SLIMHOLE}

Time of report -0800

Well number - SNLG 87-29 | Location - SE 1/4, SE 1/4, Section 29, T18N, R20E, Washoe County, NV

Days since spud - $11 \mid$ Depth today - 525' $\mid$ Hole advance last $24 \mathrm{hr}-0^{\prime} \mid$ Core recovered - $0^{\prime}$

Last casing - 4-1/2", $11.5 \mathrm{lb} / \mathrm{ft} @$ (a) 524'

BITS -- Now drilling " hole | Rotary speed - rpm; WOB - Klb; Rate of Penetration - $\mathrm{ft} / \mathrm{hr}$

Bit number | Type | Depth in, KB | Depth out, KB | Footage | Hours

$1 \quad 12-1 / 4^{\prime \prime}$ tri-cone $10^{\prime} \quad 12^{\prime} \quad 162$

$2 \quad$ HQ impreg $\quad 12^{\prime} \quad 172^{\prime} \quad 160 \quad 16$

$3 \quad 8-1 / 2^{\prime \prime}$ tri-cone $\quad 12^{\prime} \quad 176^{\prime} \quad 164 \quad 12$

$4 \quad 6-1 / 4^{\prime \prime}$ impreg $\quad 110^{\prime}$ (cement) $225^{\prime} \quad 115$

$5 \quad 6-1 / 4^{\prime \prime}$ impreg $\quad 225^{\prime} \quad 462^{\prime} \quad 237$

$6 \quad 6-1 / 4^{\prime \prime}$ impreg $\quad 462^{\prime} \quad 525^{\prime} \quad 63$

Drilling fluid - $\mathrm{n} / \mathrm{a}$

Lithology of core logged since yesterday: [Summary - detailed log available]

Core from $510^{\prime}$ to $525^{\prime}$ is still granodiorite, containing the end of the massive calcite vein described earlier.

Summary of events last 24 hours:

Repeated temperature loggs while pumping "cold" $\left(75^{\circ}\right)$ water into the annulus between the 4-1/2" casing indicate that the the top of cement is between $220^{\prime}$ and $230^{\prime}$. Called wireline company to perforate casing; nippled up BOP while waiting, performed required pressure test on BOP. Perforated casing from $220^{\prime}$ to $230^{\prime}$.

Report by: John Finger 


\section{DAILY DRILLING REPORT - 08/01/93 \\ STEAMBOAT HILLS EXPLORATORY SLIMHOLE}

Time of report -0800

Well number - SNLG 87-29 | Location - SE 1/4, SE 1/4, Section 29, T18N, R20E, Washoe County, NV

Days since spud - $12 \mid$ Depth today - 525' $\mid$ Hole advance last $24 \mathrm{hr}-0^{\prime} \mid$ Core recovered - $0^{\prime}$

Last casing - 4-1/2", $11.5 \mathrm{lb} / \mathrm{ft} @ 524^{\prime}$

BITS -- Now drilling " hole|Rotary speed - rpm; WOB - Klb; Rate of Penetration - $\mathrm{ft} / \mathrm{hr}$

Bit number | Type | Depth in, KB | Depth out, KB | Footage | Hours

1 12-1/4" tri-cone $10^{\prime} \quad 12^{\prime} \quad 12$

2. HQ impreg $\quad 12^{\prime} \quad 172^{\prime} \quad 160 \quad 16$

$3 \quad 8-1 / 2^{\prime \prime}$ tri-cone $\quad 12^{\prime} \quad 176^{\prime} \quad 164 \quad 12$

$4 \quad 6-1 / 4^{\prime \prime}$ impreg $\quad 110^{\prime}$ (cement) $225^{\prime} \quad 115$

$5 \quad 6-1 / 4^{\prime \prime}$ impreg $\quad 225^{\prime} \quad 462^{\prime} \quad 237$

$6 \quad 6-1 / 4^{\prime \prime}$ impreg $\quad 462^{\prime} \quad 525^{\prime} \quad 63$

Drilling fluid - water, bentonite, polymer; MagmaFiber and paper LCM

Flow rate - $25 \mathrm{gal} / \mathrm{min} \mid$ Pressure - psi | Returns temp - $155^{\circ} \mathrm{F} \mid$

$\mathrm{Wt}-8.5 \mathrm{lb} / \mathrm{gal}|\mathrm{Vis}-36 \mathrm{sec}| \mathrm{PV}-10 \mathrm{cP}\left|\mathrm{YP}-4 \mathrm{lb} / 100 \mathrm{ft}^{2}\right| \mathrm{pH}-12$ (drilling cement)

Lost circulation - none (drilling in casing)

Lithology of core logged since yesterday: [Summary - detailed log available]

No new core

Summary of events last 24 hours:

After perforating tools are clear of hole, rig up to pump cement. One stand drill pipe in BOP pipe rams has a tee on top; one leg to Halliburton pumper, one leg to rig pump. Pump cement until we get good returns at surface ( $\sim 85 \mathrm{cu}$ $\mathrm{ft}$ ) and shut in cement line. Pump 70 gal mud with rig pump (calculated volume to displace cement out of drill pipe and halfway to perforations) Shut in mud line. Keep filling annulus from top as cement falls back, but very little is requiired (< 10 gal). WOC 12 hours and core into top of cement with HQ core tools; cements is hard. Core past perforations and test to $100 \mathrm{psi}$ at wellhead. Perforations do not leak. Drilling cement.toward shoe.

Report by: John Finger 


\section{DAILY DRILLING REPORT - 08/02/93 \\ STEAMBOAT HILLS EXPLORATORY SLIMHOLE \\ Time of report -0800}

Well number - SNLG 87-29| Location - SE 1/4, SE 1/4, Section 29, T18N, R20E, Washoe County, NV

Days since spud - 13 | Depth today - 637' | Hole advance last $24 \mathrm{hr}-112^{\prime} \mid$ Core recovered - 112'

Last casing - 4-1/2", $11.5 \mathrm{lb} / \mathrm{ft} @ 524^{\prime}$

BITS -- Now drilling " hole | Rotary speed - rpm; WOB - Klb; Rate of Penetration - $\mathrm{ft} / \mathrm{hr}$

\begin{tabular}{c|c|ccc|c} 
Bit number & Type & Depth in, KB | & Depth out, KB | & Footage & Hours \\
1 & $12-1 / 4^{\prime \prime}$ tri-cone & $10^{\prime}$ & $12^{\prime}$ & 2 & 2 \\
2 & HQ impreg & $12^{\prime}$ & $172^{\prime}$ & 160 & 16 \\
3 & $8-1 / 2^{\prime \prime}$ tri-cone & $12^{\prime}$ & $176^{\prime}$ & 164 & 12 \\
4 & $6-1 / 4^{\prime \prime}$ impreg & $110^{\prime}$ (cement) & $225^{\prime}$ & 115 & \\
5 & $6-1 / 4^{\prime \prime}$ impreg & $225^{\prime}$ & $462^{\prime}$ & 237 & \\
6 & $6-1 / 4^{\prime \prime}$ impreg & $462^{\prime}$ & $525^{\prime}$ & 63 & \\
7 & HQ impreg & $525^{\prime}$ (rock) & & &
\end{tabular}

Drilling fluid - water, bentonite, polymer; MagmaFiber and paper LCM

Flow rate $-25 \mathrm{gal} / \mathrm{min}$ | Pressure - psi | Returns temp - $155^{\circ} \mathrm{F}$ |

$\mathrm{Wt}-8.5 \mathrm{lb} / \mathrm{gal}|\mathrm{Vis}-36 \mathrm{sec}| \mathrm{PV}-10 \mathrm{cP}\left|\mathrm{YP}-4 \mathrm{lb} / 100 \mathrm{ft}^{2}\right| \mathrm{pH}-12$ (drilling cement)

Lost circulation - none (drilling in casing)

Lithology of core logged since yesterday: [Summary - detailed log available]

Not yet logged

Summary of events last 24 hours:

Drilled cement out of casing; good contact between cement and formation below shoe. Drilled ahead in granodiorite. Lost returns at $0330\left(\sim 637^{\prime}\right)$ but fracture was relatively minor. Getting $50 \%+$ returns with $\mathrm{LCM}$, decided fracture is not big enough to flow test. Continue drilling..

Report by: John Finger 


\section{DAILY DRILLING REPORT - 08/03/93 \\ STEAMBOAT HILLS EXPLORATORY SLIMHOLE \\ Time of report -0800}

Well number - SNLG 87-29| Location - SE 1/4, SE 1/4, Section 29, T18N, R20E, Washoe County, NV

Days since spud - 14| Depth today - 783' | Hole advance last $24 \mathrm{hr}-146^{\prime} \mid$ Core recovered - 146'

Last casing - 4-1/2", $11.5 \mathrm{lb} / \mathrm{ft} @$, 524'

BITS -- Now drilling 3.89" hole | Rotary speed - rpm; WOB - Klb; Rate of Penetration - 5-6 ft/hr

Bit number | Type | Depth in, KB | Depth out, KB | Footage | Hours

$\begin{array}{lccccc}1 & 12-1 / 4^{\prime \prime} \text { tri-cone } & 10^{\prime} & 12^{\prime} & 2 & 2 \\ 2 & \text { HQ impreg } & 12^{\prime} & 172^{\prime} & 160 & 16 \\ 3 & 8-1 / 2^{\prime \prime} \text { tri-cone } & 12^{\prime} & 176^{\prime} & 164 & 12 \\ 4 & 6-1 / 4^{\prime \prime} \text { impreg } & 110^{\prime} \text { (cement) } & 225^{\prime} & 115 & \\ 5 & 6-1 / 4^{\prime \prime} \text { impreg } & 225^{\prime} & 462^{\prime} & 237 & \\ 6 & 6-1 / 4^{\prime \prime} \text { impreg } & 462^{\prime} & 525^{\prime} & 63 & \\ 7 & \text { HQ impreg } & 525^{\prime} \text { (rock) } & 673 & 148 & \\ 8 & \text { HQ impreg } & 673^{\prime} & & & \end{array}$

Drilling fluid - water, bentonite, polymer; MagmaFiber and paper LCM

Flow rate $-25 \mathrm{gal} / \mathrm{min} \mid$ Pressure - psi $\mid$ Returns temp - $155^{\circ} \mathrm{F} \mid$

$\mathrm{Wt}-8.5 \mathrm{lb} / \mathrm{gal}|\mathrm{Vis}-42 \mathrm{sec}| \mathrm{PV}-15 \mathrm{cP}\left|\mathrm{YP}-10 \mathrm{lb} / 100 \mathrm{ft}^{2}\right| \mathrm{pH}-8.0$

Lost circulation - varying from $50 \%$ to total

Lithology of core logged since yesterday: [Summary - detailed log available]

Not yet logged

Summary of events last 24 hours:

Have been drilling the same type of granodiorite seen since $225^{\prime}$, although the core has contained many fractures, mostly calcite-filled. Fluid returns have disappeared completely at times, but at least partial returns have been regained with lost circulation material. Since previous drilling here indicates that losses will be total and irretrievable when we hit a major, productive fracture, we have not interpreted the fluid losses so far as signalling a potential flow/injection test.

Deviation survey at $528^{\prime}$ gives inclination $=1^{\circ}$.

Report by: John Finger 


\section{DAILY DRILLING REPORT - 08/04/93 \\ STEAMBOAT HILLS EXPLORATORY SLIMHOLE}

Time of report -0800

Well number - SNLG 87-29 | Location - SE 1/4, SE 1/4, Section 29, T18N, R20E, Washoe County, NV

Days since spud - 15 | Depth today - 835' | Hole advance last $24 \mathrm{hr}-52^{\prime} \mid$ Core recovered - 49' Last casing - 4-1/2", $11.5 \mathrm{lb} / \mathrm{ft}$ (a) 524'

BITS -- Now drilling 3.89" hole | Rotary speed - rpm; WOB - Klb; Rate of Penetration - 5-6 ft/hr

\begin{tabular}{c|ccc|c|c} 
Bit number & Type & Depth in, KB | & Depth out, KB | & Footage | & Hours \\
1 & $12-1 / 4^{\prime \prime}$ tri-cone & $10^{\prime}$ & $12^{\prime}$ & 2 & 2 \\
2 & HQ impreg & $12^{\prime}$ & $172^{\prime}$ & 160 & 16 \\
3 & $8-1 / 2^{\prime \prime}$ tri-cone & $12^{\prime}$ & $176^{\prime}$ & 164 & 12 \\
4 & $6-1 / 4^{\prime \prime}$ impreg & $110^{\prime}$ (cement) & $225^{\prime}$ & 115 & \\
5 & $6-1 / 4^{\prime \prime}$ impreg & $225^{\prime}$ & $462^{\prime}$ & 237 & \\
6 & $6-1 / 4^{\prime \prime}$ impreg & $462^{\prime}$ & $525^{\prime}$ & 63 & \\
7 & HQ impreg & $525^{\prime}$ (rock) & 673 & 148 & \\
8 & HQ impreg & $673^{\prime}$ & & &
\end{tabular}

Drilling fluid - $\mathrm{n} / \mathrm{a}$

Lithology of core logged since yesterday: [Summary - detailed log available]

Formation from $521^{\prime}$ to $653^{\prime}$ is still the granodiorite previously described, will the following features:

$522^{\prime}-582^{\prime}$ Background of spiderweb fractures; typically $1 \mathrm{~mm}$ fractures, mostly calcite-filled, at 70 to $90^{\circ}$ from horizontal

$582^{\prime}-583^{\prime}$ More hydrothermally altered; gougable with knife blade

$583^{\prime}-652$ Mostly same as above $582^{\prime}$; fractures generally at lower angle $\left(45^{\circ}-60^{\circ}\right)$; transition to lighter colored granodiorite at $609^{\prime}$; occasional $3-5 \mathrm{~cm}$ xenoliths.

Summary of events last 24 hours:

Continued drilling the same type of granodiorite seen since 225 ', with lost circulation varying from 50 to $90 \%$. Major drilling break at 816'; lowered bit 2+ feet without rotating. Fluid level in hole fell below 300', although it later returned to the previous level of $100-150^{\prime}$. Drilled ahead without returns to $835^{\prime}, \mathrm{POOH}$ with drill pipe and began rigging up flow equipment. Did temperature log while rigging up. After all connections completed, pressurized wellhead to $100 \mathrm{psi}$ with air compressor (to force upper, colder fluid deeper into the hole), left it for an hour and released pressure. Well did not flow. Did another temperature log and found that the hole had heated up about $40^{\circ} \mathrm{F}$ since previous log. Pressurized hole again and decided to leave it for $\sim 8$ hours (until 0630.) Released pressure at 0630 ; well still did not flow. Tried 8 cycles of pressure/quick release; still no flow. Going to get higher-pressure compressor and rigging for air-lift. If well will still not flow, will go to injection test. Waiting on logging company.

Report by: John Finger 


\section{DAILY DRILLING REPORT - 08/05/93 \\ STEAMBOAT HILLS EXPLORATORY SLIMHOLE \\ Time of report -0800}

Well number - SNLG 87-29 | Location - SE 1/4, SE 1/4, Section 29, T18N, R20E, Washoe County, NV

Days since spud - 16 | Depth today - 968' | Hole advance last $24 \mathrm{hr}-133^{\prime} \mid$ Core recovered - 133'

Last casing - 4-1/2", $11.5 \mathrm{lb} / \mathrm{ft} @ 524^{\prime}$

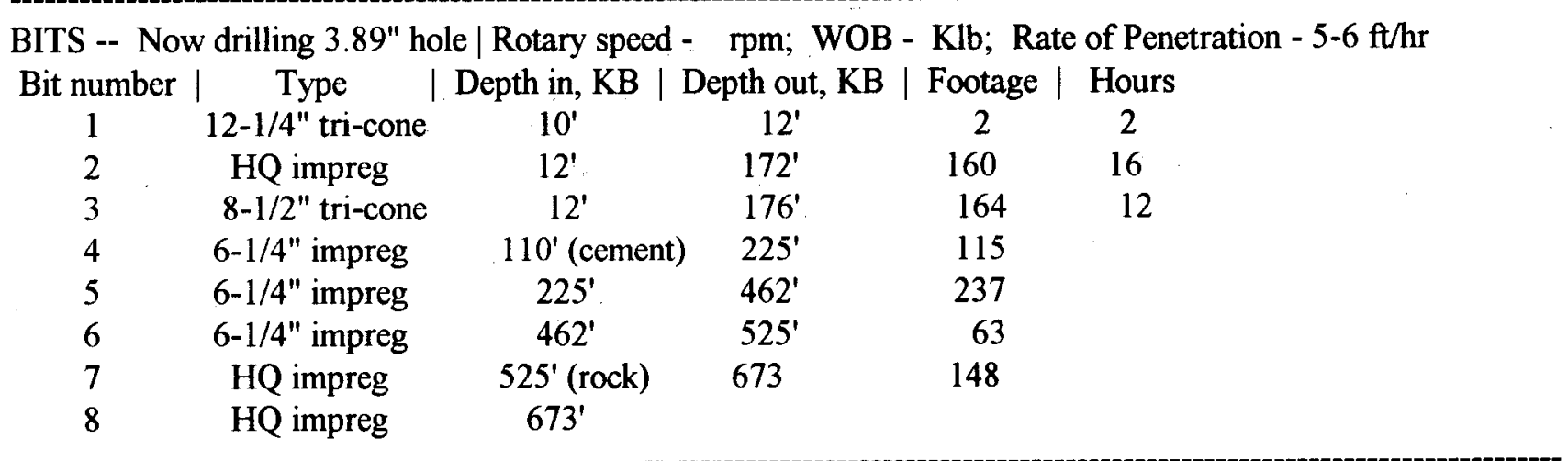

Drilling fluid - water, bentonite, polymer; MagmaFiber and paper LCM

Flow rate $-25 \mathrm{gal} / \mathrm{min} \mid$ Pressure - $\mathrm{psi} \mid$ Returns temp - $155^{\circ} \mathrm{F} \mid$

Wt $-8.5 \mathrm{lb} / \mathrm{gal}$ | Vis - xx sec | PV - xx cP | YP - xx lb/100ft ${ }^{2} \mid \mathrm{pH}-\mathrm{xxx}$

Lost circulation - no returns since major fracture at $8^{1} 6^{\prime}$

Lithology of core logged since yesterday: [Summary - detailed log available]

Core from $642^{\prime}$ to $788^{\prime}$ is weakly to moderately altered, light green-gray to whitish granodiorite with many calcite-

filled fractures, mostly at $45-60^{\circ}$ from horizontal. It also has the following features:

$657^{\prime}$ Dog-tooth calcite fills fractures

680 ' Filled fractures are prevalent and pervasive below this depth.

$708^{\prime}$ Open $2-3 \mathrm{~cm}$ fracture

Summary of events last 24 hours:

Trying larger air compressor still did not start well flowing. Apparent lack of permeability and/or fluid indicated that an injection test would not be worthwhile. Reconfigured wellhead so that we can drill through the flow tee; resumed drilling at 1215 . Drilled through approximately $80^{\prime}\left(868^{\prime}-948^{\prime}\right)$ of steeply dipping, highly mineralized fractures which do not fit closely when reassembled (i.e., there should be significant apertures downhole.) Rigging up to run temperature log; air compressor is on site to try an air-lift for starting flow.

Report by: John Finger 


\section{DAILY DRILLING REPORT - 08/06/93 \\ STEAMBOAT HILLS EXPLORATORY SLIMHOLE}

Time of report -0800

Well number - SNLG 87-29| Location - SE 1/4, SE 1/4, Section 29, T18N, R20E, Washoe County, NV

Days since spud - 17| Depth today - 968' | Hole advance last $24 \mathrm{hr}-0^{\prime} \mid$ Core recovered $-0^{\prime}$

Last casing - 4-1/2", $11.5 \mathrm{lb} / \mathrm{ft} @ 524$

BITS -- Now drilling 3.89" hole | Rotary speed - rpm; WOB - Klb; Rate of Penetration - 5-6 ft/hr

\begin{tabular}{c|cccccc} 
Bit number & Type & Depth in, KB | & Depth out, KB | Footage | Hours \\
1 & $12-1 / 4^{\prime \prime}$ tri-cone & $10^{\prime}$ & $12^{\prime}$ & 2 & 2 \\
2 & HQ impreg & $12^{\prime}$ & $172^{\prime}$ & 160 & 16 \\
3 & $8-1 / 2^{\prime \prime}$ tri-cone & $12^{\prime}$ & $176^{\prime}$ & 164 & 12 \\
4 & $6-1 / 4^{\prime \prime}$ impreg & $110^{\prime}$ (cement) & $225^{\prime}$ & 115 & \\
5 & $6-1 / 4^{\prime \prime}$ impreg & $225^{\prime}$ & $462^{\prime}$ & 237 & \\
6 & $6-1 / 4^{\prime \prime}$ impreg & $462^{\prime}$ & $525^{\prime}$ & 63 & \\
7 & HQ impreg & $525^{\prime}$ (rock) & 673 & 148 \\
8 & HQ impreg & $673^{\prime}$ & & &
\end{tabular}

Drilling fluid - $\mathrm{n} / \mathrm{a}$

Lithology of core logged since yesterday: [Summary - detailed log available]

Core from $792^{\prime}$ to $828^{\prime}$ is weakly altered, light green-gray to whitish granodiorite with mica, many calcite-filled fractures, mostly at $60-70^{\circ}$ from horizontal. It also has the following features:

$797^{\prime} 1 \mathrm{~cm}$ open fracture

$815^{\prime}-823^{\prime} 5.3^{\prime}$ core lost in this interval, major drilling break indicates at least $2^{\prime}$ void, calcite coating with chloride rim at borders of fracture, multiple generations of deposition.

Summary of events last 24 hours:

Termperature $\log$ shows high temperature $\left(>160^{\circ} \mathrm{C}\right)$ in fractured interval from $868^{\prime}$ to $948^{\prime}$, indicating high permeability in that interval. Will try air-lifting from about 250' (inside casing). Compressor is rated at $100 \mathrm{psi}$, $100 \mathrm{scfm}$. Air lift is producing about $4-5 \mathrm{gpm}$, outflow temperature rises from about $135^{\circ} \mathrm{F}$ to $180^{\circ} \mathrm{F}$, but the small annulus between the H-rod and wellbore will probably prevent flow even if temperature gets near boiling. Pull rods and pressurize wellhead. Left wellhead at 100 psi for 30 min, released pressure, well did not flow. Ran back in with N-rod (2-3/4" OD) and air lift again, hoping that the larger annulus will allow lifting more water. Rig for temperature $\log$ through $\mathrm{N}$-rod before air-lift. Temperature log shows temperatures below about 150' almost identical to yesterday's last log. Begin air lift with 100 psi compressor. Temperature in flow line reaches about $199^{\circ}$, flow rate $\sim 25-28 \mathrm{gpm}$. Add larger compressor (200 psi, $300 \mathrm{scfm}$ ) into line - compressors in parallel. Temperature drops to $190^{\circ} \mathrm{F}$ and flow rates becomes very erratic, from 12 to $28 \mathrm{gpm}$. Speculation is that both compressors are blowing too much air past the water. Will take small compressor out of the circuit. When both compressors are turned off, well begins to flow on its own. Outflow temperature goes to $203^{\circ} \mathrm{F}$ (boiling at this altitude) and flow rate remains erratic at $10-30 \mathrm{gpm}$, probably because of the drill pipe in the hole. Let the well flow to clean up the fluid (get rid of drilling mud, etc) and shut in. $\mathrm{POOH}$ with $\mathrm{N}$-rods and pressurize wellhead to 150 psi with compressor. Release wellhead pressure at 2008 hours and well flows. Beginning flow rate is approximately $60 \mathrm{gpm}$ (liquid), but builds to $100+\mathrm{gpm}$ over the course of the next hour. Rig up to run wireline temperature, pressure, spinner (TPS) logs. Spinner log shows most production from major fracture at 815'. Choke flow in steps by closing wellhead valve; flow rate and wellhead temperature go down, wellhead pressure goes up. Shut in well for $\sim 7-8$ hours to watch for pressure build. Good data set from flow test; rigging up to do downhole water samples, followed by injection test.

Report by: John Finger 


\section{DAILY DRILLING REPORT - 08/07/93 \\ STEAMBOAT HILLS EXPLORATORY SLIMHOLE \\ Time of report -0800}

Well number - SNLG 87-29 | Location - SE 1/4, SE 1/4, Section 29, T18N, R20E, Washoe County, NV

Days since spud - $18 \mid$ Depth today - 1035' Hole advance last $24 \mathrm{hr}-67^{\prime} \mid$ Core recovered - 64'

Last casing - 4-1/2", $11.5 \mathrm{lb} / \mathrm{ft} @ 524^{\prime}$

BITS -- Now drilling 3.89" hole | Rotary speed - rpm; WOB - Klb; Rate of Penetration - 5-6 ft/hr

Bit number | Type | Depth in, KB | Depth out, KB | Footage | Hours

$\begin{array}{lccccc}1 & 12-1 / 4^{\prime \prime} \text { tri-cone } & 10^{\prime} & 12^{\prime} & 2 & 2 \\ 2 & \text { HQ impreg } & 12^{\prime} & 172^{\prime} & 160 & 16 \\ 3 & 8-1 / 2^{\prime \prime} \text { tri-cone } & 12^{\prime} & 176^{\prime} & 164 & 12 \\ 4 & 6-1 / 4^{\prime \prime} \text { impreg } & 110^{\prime} \text { (cement) } & 225^{\prime} & 115 & \\ 5 & 6-1 / 4^{\prime \prime} \text { impreg } & 225^{\prime} & 462^{\prime} & 237 & \\ 6 & 6-1 / 4^{\prime \prime} \text { impreg } & 462^{\prime} & 525^{\prime} & 63 & \\ 7 & \text { HQ impreg } & 525^{\prime} \text { (rock) } & 673 & 148 & \\ 8 & \text { HQ impreg } & 673^{\prime} & & \end{array}$

Drilling fluid - water, bentonite, polymer;

Flow rate - $25 \mathrm{gal} / \mathrm{min}$ | Pressure - psi | Returns temp - $\mathrm{n} / \mathbf{a}$

$\mathrm{Wt}-8.4 \mathrm{lb} / \mathrm{gal}|\mathrm{Vis}-32 \mathrm{sec}| \mathrm{PV}-6 \mathrm{cP}\left|\mathrm{YP}-2 \mathrm{lb} / 100 \mathrm{ft}^{2}\right| \mathrm{pH}-7.5$

Lost circulation - no returns since fracture at $\mathbf{8 1}^{\prime}$

Lithology of core logged since yesterday: [Summary - detailed log available]

Formation from $834^{\prime}$ to $966^{\prime}$ is still the granodiorite previously described, with many fractures in the zone from $868^{\prime}$ to $947^{\prime}$, especially the following:

$868^{\prime}$ Open $2-3 \mathrm{~cm}$ fracture at $70^{\circ}$

$888^{\prime}$ Open $1 \mathrm{~cm}$ vertical fracture, with dog-tooth spar

$912^{\prime}$ Open $5 \mathrm{~cm}$ fracture/void at $45^{\circ}$

Summary of events last 24 hours:

Opened well to conclude production shut-in test from previous night. Wellhead pressure had relaxed to zero as upper hole cooled. POOH with PTS logging tool and used LBL fluid sampler to get water sample from below the production zone (this will tell whether the produced water and that below it are chemically the same.) RIH with Sandia temperature log. Rigged up for injection test. Injection will be hot ( $\left.195^{\circ} \mathrm{F}\right)$ water from power plant injection line, step-wise injection at four flow rates (maximum first, then step down and back up), then shut in. Inject at increaseing flow rate (low wellhead pressure up to $350 \mathrm{gpm}$ causing injection line to flash; inlet temperature $\sim 220^{\circ} \mathrm{F}$ ) up to $650 \mathrm{gpm}$. Line blows off injection pump; consensus is that it will take at least two days to rebuild for high temperature, so go with cold water injection now. Do step-rate injection with cold water, and shut in well. Leave shut in for $1-1 / 2$ hours, log out of hole, and resume drilling.

Report by: John Finger 


\section{DAILY DRILLING REPORT - 08/08/93 \\ STEAMBOAT HILLS EXPLORATORY SLIMHOLE \\ Time of report -0800}

Well number - SNLG 87-29| Location - SE 1/4, SE 1/4, Section 29, T18N, R20E, Washoe County, NV

Days since spud - 19| Depth today - 1149' | Hole advance last $24 \mathrm{hr}-114^{\prime} \mid$ Core recovered - 112' Last casing - 4-1/2", $11.5 \mathrm{lb} / \mathrm{ft} @ 524^{\prime}$

BITS -- Now drilling 3.89" hole | Rotary speed - rpm; WOB - Klb; Rate of Penetration - 5-6 ft/hr

\begin{tabular}{c|ccccc} 
Bit number & Type & Depth in, KB & Depth out, KB | Footage | Hours \\
1 & $12-1 / 4^{\prime \prime}$ tri-cone & $10^{\prime}$ & $12^{\prime}$ & 2 & 2 \\
2 & HQ impreg & $12^{\prime}$ & $172^{\prime}$ & 160 & 16 \\
3 & $8-1 / 2^{\prime \prime}$ tri-cone & $12^{\prime}$ & $176^{\prime}$ & 164 & 12 \\
4 & $6-1 / 4^{\prime \prime}$ impreg & $110^{\prime}$ (cement) & $225^{\prime}$ & 115 & \\
5 & $6-1 / 4^{\prime \prime}$ impreg & $225^{\prime}$ & $462^{\prime}$ & 237 & \\
6 & $6-1 / 4^{\prime \prime}$ impreg & $462^{\prime}$ & $525^{\prime}$ & 63 & \\
7 & HQ impreg & $525^{\prime}$ (rock) & 673 & 148 & \\
8 & HQ impreg & $673^{\prime}$ & 1149 & 476
\end{tabular}

Drilling fluid - water, bentonite, polymer;

Flow rate $-25 \mathrm{gal} / \mathrm{min} \mid$ Pressure - psi $\mid$ Returns temp - n/a

Wt - $8.4 \mathrm{lb} / \mathrm{gal}|\mathrm{Vis}-32 \mathrm{sec}| \mathrm{PV}-4 \mathrm{cP}\left|\mathrm{YP}-4 \mathrm{lb} / 100 \mathrm{ft}^{2}\right| \mathrm{pH}-7.0$

Lost circulation - no returns since fracture at $815^{\prime}$

Lithology of core logged since yesterday: [Summary - detailed log available]

None today

Summary of events last 24 hours:

Have continued drilling ahead with no particular problems. Formation below $815^{\prime}$ is very similar to that below 1015'; large ( $2 \mathrm{ft})$ void followed by open, high-angle fractures. This implies that the zone at $1015^{\prime}$ could be a large production zone, as was the one at $\mathbf{8 1 5}^{\prime}$, but flow from the upper zone may suppress any production from below.

Flow from first test was unexpectedly high. Previous theoretical work indicated that the maximum total flow expected from the corehole (compared to the companion production well) was $\sim 90 \mathrm{gpm}$, but the corehole actually flowed over $100 \mathrm{gpm}$, liquid phase. This could indicate several phenomena, which we hope to resolve with further tests.

Report by: John Finger 


\section{DAILY DRILLING REPORT - 08/09/93 \\ STEAMBOAT HILLS EXPLORATORY SLIMHOLE \\ Time of report - 0800}

Well number - SNLG 87-29 | Location - SE 1/4, SE 1/4, Section 29, T18N, R20E, Washoe County, NV

Days since spud - $20 \mid$ Depth today - 1288' | Hole advance last $24 \mathrm{hr}-139^{\prime} \mid$ Core recovered - 139'

Last casing - 4-1/2", $11.5 \mathrm{lb} / \mathrm{ft} @ 524^{\prime}$

BITS -- Now drilling 3.89" hole | Rotary speed - rpm; WOB - Klb; Rate of Penetration - 5-6 ft/hr

\begin{tabular}{|c|c|c|c|c|c|}
\hline Bit number & Type & Depth in, KB I & Depth out, KB & Footage | & Hou \\
\hline 1 & $12-1 / 4^{\prime \prime}$ tri-cone & $10^{\prime}$ & $12^{\prime}$ & 2 & 2 \\
\hline 2 & HQ impreg & $12^{\prime}$ & $172^{\prime}$ & 160 & 16 \\
\hline 3 & $8-1 / 2 "$ tri-cone & $12^{\prime}$ & $176^{\prime}$ & 164 & 12 \\
\hline 4 & 6-1/4" impreg & $110^{\prime}$ (cement) & $225^{\prime}$ & 115 & \\
\hline 5 & 6-1/4" impreg & $225^{\prime}$ & $462^{\prime}$ & 237 & \\
\hline 6 & 6-1/4" impreg & $462^{\prime}$ & $525^{\prime}$ & 63 & \\
\hline 7 & HQ impreg & $525^{\prime}$ (rock) & 673 & 148 & \\
\hline 8 & HQ impreg & $673^{\prime}$ & 1149 & 476 & \\
\hline 9 & HQ impreg & 1149" & & & \\
\hline
\end{tabular}

Drilling fluid - water, bentonite, polymer;

Flow rate - $25 \mathrm{gal} / \mathrm{min} \mid$ Pressure - psi | Returns temp - $\mathrm{n} / \mathrm{a}$

$\mathrm{Wt}-8.4 \mathrm{lb} / \mathrm{gal}|\mathrm{Vis}-33 \mathrm{sec}| \mathrm{PV}-5 \mathrm{cP}\left|\mathrm{YP}-3 \mathrm{lb} / 100 \mathrm{ft}^{2}\right| \mathrm{pH}-7.0$

Lost circulation - no returns since fracture at $815^{\prime}$

Lithology of core logged since yesterday: [Summary - detailed log available]

None today

Summary of events last 24 hours:

Have continued drilling ahead with no particular problems. We have tentatively scheduled another set of tests for tomorrow - production in the daytime, injection at night (to get cooler water from the power plant) and packer isolation tests the following day.

Report by: John Finger 


\section{DAILY DRILLING REPORT - 08/10/93 \\ STEAMBOAT HILLS EXPLORATORY SLIMHOLE \\ Time of report -0800}

Well number - SNLG 87-29| Location - SE 1/4, SE 1/4, Section 29, T18N, R20E, Washoe County, NV

Days since spud - $21 \mid$ Depth today - 1478' | Hole advance last $24 \mathrm{hr}-190^{\prime} \mid$ Core recovered - 189'

Last casing - 4-1/2", $11.5 \mathrm{lb} / \mathrm{ft} @ 524^{\prime}$

BITS -- Now drilling 3.89" hole | Rotary speed - rpm; WOB - Klb; Rate of Penetration - 5-6 ft/hr

Bit number | Type | Depth in, KB | Depth out, KB | Footage | Hours

$\begin{array}{lccccc}1 & 12-1 / 4^{\prime \prime} \text { tri-cone } & 10^{\prime} & 12^{\prime} & 2 & 2 \\ 2 & \text { HQ impreg } & 12^{\prime} & 172^{\prime} & 160 & 16 \\ 3 & 8-1 / 2^{\prime \prime} \text { tri-cone } & 12^{\prime} & 176^{\prime} & 164 & 12 \\ 4 & 6-1 / 4^{\prime \prime} \text { impreg } & 110^{\prime} \text { (cement) } & 225^{\prime} & 115 & \\ 5 & 6-1 / 4^{\prime \prime} \text { impreg } & 225^{\prime} & 462^{\prime} & 237 & \\ 6 & 6-1 / 4^{\prime \prime} \text { impreg } & 462^{\prime} & 525^{\prime} & 63 & \\ 7 & \text { HQ impreg } & 525^{\prime} \text { (rock) } & 673 & 148 & \\ 8 & \text { HQ impreg } & 673^{\prime} & 1149 & 476 & \\ 9 & \text { HQ impreg } & 1149^{\prime \prime} & & & \end{array}$

Drilling fluid - water, bentonite, polymer;

Flow rate $-25 \mathrm{gal} / \mathrm{min} \mid$ Pressure - psi $\mid$ Returns temp - $\mathrm{n} / \mathrm{a}$

$\mathrm{Wt}-8.4 \mathrm{lb} / \mathrm{gal}|\mathrm{Vis}-33 \mathrm{sec}| \mathrm{PV}-5 \mathrm{cP}\left|\mathrm{YP}-3 \mathrm{lb} / 100 \mathrm{ft}^{2}\right| \mathrm{pH}-7.0$

Lost circulation - no returns since fracture at $815^{\prime}$

Lithology of core logged since yesterday: [Summary - detailed log available]

Granodiorite from $966^{\prime}$ to $1137^{\prime}$ is similar to that previously described, with the following features:

988' Open, quartz-lined $1-2 \mathrm{~cm}$ fracture at $70^{\circ}$

$1011^{\prime}$ Open, $2-3 \mathrm{~cm}$ fracture at $75^{\circ}$, dog-tooth spar in vugs

$1015^{\prime}$ Lost $\sim 2.7^{\prime}$ core in major void/fracture, quartz rubble in core tube apparently belongs in this void $1032^{\prime}-1047^{\prime}$ Significant $1-2 \mathrm{~cm}$ open fractures throughout this interval

$1111^{\prime} 3-4 \mathrm{~cm}$ vug becomes vertical $1-2 \mathrm{~cm}$ open fracture

Summary of events last 24 hours:

Have continued drilling ahead with good rate of penetration (up to $10 \mathrm{ft} / \mathrm{hr}$ ). Production test scheduled for this afternoon; waiting on logging tools, will drill until they arrive.

Report by: John Finger 


\section{DAILY DRILLING REPORT - 08/11/93 \\ STEAMBOAT HILLS EXPLORATORY SLIMHOLE \\ Time of report - 0800}

Well number - SNLG 87-29 | Location - SE 1/4, SE 1/4, Section 29, T18N, R20E, Washoe County, NV

Days since spud - 22 | Depth today - $1510^{\prime} \mid$ Hole advance last $24 \mathrm{hr}-32^{\prime} \mid$ Core recovered - 32'

Last casing - 4-1/2", $11.5 \mathrm{lb} / \mathrm{ft} @ 524^{\prime}$

BITS -- Now drilling 3.89" hole | Rotary speed - rpm; WOB - Klb; Rate of Penetration - 5-6 ft/hr

Bit number | Type | Depth in, KB | Depth out, KB | Footage | Hours

$\begin{array}{lccccc}1 & 12-1 / 4^{\prime \prime} \text { tri-cone } & 10^{\prime} & 12^{\prime} & 2 & 2 \\ 2 & \text { HQ impreg } & 12^{\prime} & 172^{\prime} & 160 & 16 \\ 3 & 8-1 / 2^{\prime \prime} \text { tri-cone } & 12^{\prime} & 176^{\prime} & 164 & 12 \\ 4 & 6-1 / 4^{\prime \prime} \text { impreg } & 110^{\prime} \text { (cement) } & 225^{\prime} & 115 & \\ 5 & 6-1 / 4^{\prime \prime} \text { impreg } & 225^{\prime} & 462^{\prime} & 237 & \\ 6 & 6-1 / 4^{\prime \prime} \text { impreg } & 462^{\prime} & 525^{\prime} & 63 & \\ 7 & \text { HQ impreg } & 525^{\prime} \text { (rock) } & 673 & 148 & \\ 8 & \text { HQ impreg } & 673^{\prime} & 1149 & 476 & \\ 9 & \text { HQ impreg } & 1149^{\prime \prime} & & & \end{array}$

Drilling fluid - water, bentonite, polymer;

Flow rate - $25 \mathrm{gal} / \mathrm{min} \mid$ Pressure - $\mathrm{psi} \mid$ Returns temp - $\mathrm{n} / \mathbf{a}$

$\mathrm{Wt}-8.4 \mathrm{lb} / \mathrm{gal}|\mathrm{Vis}-33 \mathrm{sec}| \mathrm{PV}-3 \mathrm{cP}\left|\mathrm{YP}-2 \mathrm{lb} / 100 \mathrm{ft}^{2}\right| \mathrm{pH}-9.0$

Lost circulation - no returns since fracture at $815^{\prime}$

Lithology of core logged since yesterday: [Summary - detailed log available]

Granodiorite from $1118^{\prime}$ to $1288^{\prime}$ is similar to that previously described, with the following features:

$1118^{\prime}-1123^{\prime}$ Lost $1.6^{\prime}$ core in this interval of mixed rock with multiple shear zone

$1152^{\prime}-1157^{\prime} 1-2 \mathrm{~cm}$ open fractures in this zone

$1180^{\prime} \quad$ Highly altered rubble zone

1256'-1262' Zone of complex 1-2cm vuggy, open "see-through" fractures, some with dog-tooth spar

Summary of events last 24 hours:

Continued drilling ahead to $1510^{\prime}$ while waiting for logging tools to arrive and rig up. After tools are on site, begin air-lifting fluid out of core hole to stimulate it to flow. Flow begins and stabilizes, slightly lower rate than first test ( $95 \mathrm{gpm}$ max vs $103 \mathrm{gpm}$ ). Perform temperature-pressure-spinner surveys up and down hole while flowing, then shut-in wellbore with TPS tool hanging at 808' to collect pressure build-up data. Appear to have good data set for production test. Rigging up for injection test.

Report by: John Finger 
DAILY DRILLING REPORT - 08/12/93

STEAMBOAT HILLS EXPLORATORY SLIMHOLE

Time of report -0800

Well number - SNLG 87-29 | Location - SE 1/4, SE 1/4, Section 29, T18N, R20E, Washoe County, NV

Days since spud - 23 | Depth today - 1563 | Hole advance last $24 \mathrm{hr}-53^{\prime} \mid$ Core recovered - 53' Last casing - 4-1/2", $11.5 \mathrm{lb} / \mathrm{ft} @ 524^{\prime}$

BITS -- Now drilling 3.89" hole | Rotary speed - rpm; WOB - Klb; Rate of Penetration - 5-6 ft/hr Bit number | Type | Depth in, KB | Depth out, KB | Footage | Hours

$\begin{array}{lccccc}1 & 12-1 / 4^{\prime \prime} \text { tri-cone } & 10^{\prime} & 12^{\prime} & 2 & 2 \\ 2 & \text { HQ impreg } & 12^{\prime} & 172^{\prime} & 160 & 16 \\ 3 & 8-1 / 2^{\prime \prime} \text { tri-cone } & 12^{\prime} & 176^{\prime} & 164 & 12 \\ 4 & 6-1 / 4^{\prime \prime} \text { impreg } & 110^{\prime} \text { (cement) } & 225^{\prime} & 115 & \\ 5 & 6-1 / 4^{\prime \prime} \text { impreg } & 225^{\prime} & 462^{\prime} & 237 & \\ 6 & 6-1 / 4^{\prime \prime} \text { impreg } & 462^{\prime} & 525^{\prime} & 63 & \\ 7 & \text { HQ impreg } & 525^{\prime} \text { (rock) } & 673 & 148 & \\ 8 & \text { HQ impreg } & 673^{\prime} & 1149 & 476 & \\ 9 & \text { HQ impreg } & 1149^{\prime \prime} & 1510 & 361\end{array}$

Drilling fluid - water, bentonite, polymer; Flow rate - $25 \mathrm{gal} / \mathrm{min} \mid$ Pressure - psi | Returns temp - n/a

$\mathrm{Wt}-8.4 \mathrm{lb} / \mathrm{gal}|\mathrm{Vis}-33 \mathrm{sec}| \mathrm{PV}-3 \mathrm{cP}\left|\mathrm{YP}-2 \mathrm{lb} / 100 \mathrm{ft}^{2}\right| \mathrm{pH}-9.5$

Lost circulation - no returns since fracture at $815^{\prime}$

Lithology of core logged since yesterday: [Summary - detailed log available]

Granodiorite from $1271^{\prime}$ to $1488^{\prime}$ is similar to that previously described, with the following features:

$1283^{\prime}-1323^{\prime}$ This zone has at least one $1 \mathrm{~cm}$ or larger fracture, at $15-75^{\circ}$, in each $10^{\prime}$ interval

$1346^{\prime}-1364^{\prime} 1-2 \mathrm{~cm}$ open fractures, at $75-80^{\circ}$, in this zone

$1399^{\prime}-1414^{\prime}$ Highly altered shear zone, with some open fractures

$1449^{\prime}-1460^{\prime}$ More altered/shear zone, with series of $1 \mathrm{~cm}$ open fractures

Summary of events last 24 hours:

Begin injection test with hot $\left(195^{\circ}\right)$ water from power plant; recorded data for one flow rate, hose on injection pump fails. Rig down pump and begin replacing hoses with pipe. Rig up to run packer; will pack off zone at 690', separating producing interval at $815^{\prime}$ from interval at $\sim 640^{\prime}$ which appears to take all the injected water. RIH with packer on N-rod, which will allow injection down annulus as well as through pipe, and set at $690^{\prime}$. Pressurize packer to sit it, and begin logging down pipe, through packer, and into open hole while pumping hot water into the annulus. Temperature data is anomalous, appearing isothermal across packer, so we conclude test and start to pull out of the hole. Packer requires no force to move it (i.e., it is deflated). Lay down packer and disassemble it; 0ring has failed. Will refurbish both packers with different $O$-rings. Resume drilling ahead at $1510^{\prime}$.

Report by: John Finger 


\section{DAILY DRILLING REPORT - 08/13/93 \\ STEAMBOAT HILLS EXPLORATORY SLIMHOLE}

Time of report -0800

Well number - SNLG 87-29| Location - SE 1/4, SE 1/4, Section 29, T18N, R20E, Washoe County, NV

Days since spud - $24 \mid$ Depth today - 1670' | Hole advance last $24 \mathrm{hr}-107^{\prime} \mid$ Core recovered - 107' Last casing - 4-1/2", $11.5 \mathrm{lb} / \mathrm{ft} @ 524^{\prime}$

\begin{tabular}{|c|c|c|c|c|c|}
\hline Bit number | & | Type & | Depth in, KB | & Depth out, KB & | Footage | & Hours \\
\hline 1 & 12-1/4" tri-cone & $10^{\prime}$ & $12^{\prime}$ & 2 & 2 \\
\hline 2 & HQ impreg & $12^{\prime}$ & $172^{\prime}$ & 160 & 16 \\
\hline 3 & $8-1 / 2^{\prime \prime}$ tri-cone & $12^{\prime}$ & $176^{\prime}$ & 164 & 12 \\
\hline 4 & 6-1/4" impreg & $110^{\prime}$ (cement) & $225^{\prime}$ & 115 & \\
\hline 5 & $6-1 / 4^{\prime \prime}$ impreg & $225^{\prime}$ & $462^{\prime}$ & 237 & \\
\hline 6 & 6-1/4" impreg & $462^{\prime}$ & $525^{\prime}$ & 63 & \\
\hline 7 & HQ impreg & $525^{\prime}$ (rock) & 673 & 148 & \\
\hline 8 & HQ impreg & $673^{\prime}$ & 1149 & 476 & \\
\hline 9 & HQ impreg & $1149^{\prime}$ & 1510 & 361 & \\
\hline 10 & HQ test bit & $1510^{\prime}$ & $1568^{\prime}$ & 58 & \\
\hline 11 & HQ surf set & $1568^{\prime}$ & $1600^{\prime}$ & 32 & \\
\hline 12 & HQ impreg & $1600^{\prime}$ & & & \\
\hline
\end{tabular}

Drilling fluid - water, bentonite, polymer;

Flow rate $-25 \mathrm{gal} / \mathrm{min}$ | Pressure - psi | Returns temp - n/a

Wt $-8.4 \mathrm{lb} / \mathrm{gal} \mid \mathrm{Vis}-33 \mathrm{sec}$ | PV $-4 \mathrm{cP}$ |YP $-4 \mathrm{lb} / 100 \mathrm{ft}^{2} \mid \mathrm{pH}-8.5$

Lost circulation - no returns since fracture at $815^{\prime}$

Lithology of core logged since yesterday: [Summary - detailed log available]

None logged

Summary of events last 24 hours:

Have been drilling ahead for the last 24 hours with no problems, although overall progress has been reduced by two bit changes to try different kinds of bits. We are now drilling with the same type of bit (\#7 impregnated) that has previously given satisfactory performance. Both packers have been completely refurbished with new Viton $\mathbf{0}$ rings; apparent cause of previous failure was improper rings. Tentative plan is to drill ahead throughout the weekend and resume injection and packer tests on Monday.

Report by: John Finger 


\section{DAILY DRILLING REPORT - 08/14/93 \\ STEAMBOAT HILLS EXPLORATORY SLIMHOLE \\ Time of report -0800}

Well number - SNLG 87-29 | Location - SE 1/4, SE 1/4, Section 29, T18N, R20E, Washoe County, NV

Days since spud - 25 | Depth today - 1709' | Hole advance last $24 \mathrm{hr}-39^{\prime} \mid$ Core recovered - $39^{\prime}$

Last casing - 4-1/2", $11.5 \mathrm{lb} / \mathrm{ft}$ (a) 524'

\begin{tabular}{|c|c|c|c|c|c|}
\hline Bit number & Type & Depth in, KB | I & Depth out, KB & Footage & Hours \\
\hline 1 & $12-1 / 4 "$ tri-cone & $10^{\prime}$ & $12^{\prime}$ & 2 & 2 \\
\hline 2 & HQ impreg & $12^{\prime}$ & $172^{\prime}$ & 160 & 16 \\
\hline 3 & $8-1 / 2^{\prime \prime}$ tri-cone & $12^{\prime}$ & $176^{\prime}$ & 164 & 12 \\
\hline 4 & 6-1/4" impreg & $110^{\prime}$ (cement) & $225^{\prime}$ & 115 & \\
\hline 5 & 6-1/4" impreg & $225^{\prime}$ & $462^{\prime}$ & 237 & \\
\hline 6 & $6-1 / 4^{\prime \prime}$ impreg & $462^{\prime}$ & $525^{\prime}$ & 63 & \\
\hline 7 & HQ impreg & $525^{\prime}$ (rock) & 673 & 148 & \\
\hline 8 & HQ impreg & $673^{\prime}$ & 1149 & 476 & \\
\hline 9 & HQ impreg & $1149^{\prime}$ & $1510^{\prime}$ & 361 & \\
\hline 10 & HQ test bit & $1510^{\prime}$ & $1568^{\prime}$ & 58 & \\
\hline 11 & HQ surf set & $1568^{\prime}$ & $1600^{\prime}$ & 32 & \\
\hline 12 & HQ impreg & $1600^{\prime}$ & $1702^{\prime}$ & 102 & \\
\hline 13 & HQ test bit & $1702^{\prime}$ & $1709^{\prime}$ & 7 & \\
\hline 14 & HQ surf set & $1709^{\prime}$ & & & \\
\hline
\end{tabular}

Drilling fluid - water, bentonite, polymer; soda ash

Flow rate $-25 \mathrm{gal} / \mathrm{min}$ | Pressure - psi | Returns temp - n/a

$\mathrm{Wt}-8.4 \mathrm{lb} / \mathrm{gal}$ | Vis $-31 \mathrm{sec}|\mathrm{PV}-2 \mathrm{cP}| \mathrm{YP}-3 \mathrm{lb} / 100 \mathrm{ft}^{2} \mid \mathrm{pH}-8.5$

Lost circulation - no returns since fracture at $815^{\prime}$

Lithology of core logged since yesterday: [Summary - detailed log available]

None logged today

Summary of events last 24 hours:

Have been drilling ahead for the last 24 hours with low overall penetration because of severe bit wear. Formation has not changed significantly, but there is considerable vibration in the drill string. This vibration, which is usually destructive to bits, could be caused by lost circulation combined with water inflow to the wellbore; this would eliminate the lubricating effect of the drilling fluid and cause intermittent torque in the upper part of the hole. We will try slugging the fluid with LCM to improve the mud column in the annulus; we have also been pumping a separate drilling fluid stream down the annulus while drilling.

Report by: John Finger 


\section{DAILY DRILLING REPORT - 08/15/93 \\ STEAMBOAT HILLS EXPLORATORY SLIMHOLE \\ Time of report -0800}

Well number - SNLG 87-29 | Location - SE 1/4, SE 1/4, Section 29, T18N, R20E, Washoe County, NV

Days since spud - 26 | Depth today - 1828' | Hole advance last $24 \mathrm{hr}-119^{\prime} \mid$ Core recovered - 119'

Last casing - 4-1/2", $11.5 \mathrm{lb} / \mathrm{ft} @ 524^{\prime}$

BITS -- Now drilling 3.89" hole | Rotary speed - rpm; WOB - Klb; Rate of Penetration - 5-6 ft/hr

\begin{tabular}{c|c|ccc|c} 
Bit number & Type & Depth in, KB | & Depth out, KB | & Footage & Hours \\
1 & $12-1 / 4^{\prime \prime}$ tri-cone & $10^{\prime}$ & $12^{\prime}$ & 2 & 2 \\
2 & HQ impreg & $12^{\prime}$ & $172^{\prime}$ & 160 & 16 \\
3 & $8-1 / 2^{\prime \prime}$ tri-cone & $12^{\prime}$ & $176^{\prime}$ & 164 & 12 \\
4 & $6-1 / 4^{\prime \prime}$ impreg & $110^{\prime}$ (cement) & $225^{\prime}$ & 115 & \\
5 & $6-1 / 4^{\prime \prime}$ impreg & $225^{\prime}$ & $462^{\prime}$ & 237 \\
6 & $6-1 / 4^{\prime \prime}$ impreg & $462^{\prime}$ & $525^{\prime}$ & 63 \\
7 & HQ impreg & $525^{\prime}$ (rock) & 673 & 148 \\
8 & HQ impreg & $673^{\prime}$ & 1149 & 476 \\
9 & HQ impreg & $1149^{\prime}$ & $1510^{\prime}$ & 361 \\
10 & HQ test bit & $1510^{\prime}$ & $1568^{\prime}$ & 58 \\
11 & HQ surf set & $1568^{\prime}$ & $1600^{\prime}$ & 32 \\
12 & HQ impreg & $1600^{\prime}$ & $1702^{\prime}$ & 102 \\
13 & HQ test bit & $1702^{\prime}$ & $1709^{\prime}$ & 7 \\
14 & HQ surf set & $1709^{\prime}$ & $1754^{\prime}$ & 45 \\
15 & HQ test bit & $1754^{\prime}$ & &
\end{tabular}

Drilling fluid - water, bentonite, polymer; soda ash

Flow rate $-25 \mathrm{gal} / \mathrm{min}$ | Pressure - psi $\mid$ Returns temp - $\mathrm{n} / \mathrm{a}$

Wt $-8.4 \mathrm{lb} / \mathrm{gal}$ | Vis - $32 \mathrm{sec}$ | PV - $3 \mathrm{cP}$ | YP - $3 \mathrm{lb} / 100 \mathrm{ft}^{2} \mid \mathrm{pH}-8.5$

Lost circulation - no returns since fracture at $815^{\prime}$

Lithology of core logged since yesterday: [Summary - detailed log available]

Core from $1467^{\prime}$ to $1745^{\prime}$ is generally the same granodiorite previously described, with the following features:

$1530^{\prime}-1546^{\prime}$ Heavily altered granodiorite, clayey in spots, mechanically sheared, with at least one $2 \mathrm{~cm}$ fracture

$1607^{\prime}-1613^{\prime}$ Altered zone as above

$1625^{\prime}-1638^{\prime}$ Intrusion (probably a dike) of fine-grained basalt, contact at $75^{\circ}$ from horizontal

$1638^{\prime}-1642^{\prime}$ Contact area below basalt is heavily altered granodiorite as above

Summary of events last 24 hours:

Have been drilling ahead for the last 24 hours with somewhat better penetration and bit performance. Have laid down 20' core barrel and gone back to $10^{\prime}$ barrel. It is not clear why this should make a difference in bit wear, but drilling has improved since the change. Still pumping drilling fluid down the annulus. Slightly lower penetration rate in the basalt intrusion described above.

Ran televiewer in one of the smaller (3") core holes in this field while pumping cooling water down around the tool; it produced a good picture with reliable performance at $110^{\circ} \mathrm{C}$, becoming erratic as temperature approached $130^{\circ} \mathrm{C}$. This opens the possibility of logging smaller holes in this and other locations, thereby providing better definition of reservoir characteristics.

Report by: John Finger 


\section{DAILY DRILLING REPORT - 08/16/93 \\ STEAMBOAT HILLS EXPLORATORY SLIMHOLE \\ Time of report - 0800}

Well number - SNLG 87-29 | Location - SE 1/4, SE 1/4, Section 29, T18N, R20E, Washoe County, NV

Days since spud - 27| Depth today - 1908' Hole advance last $24 \mathrm{hr}-80^{\prime} \mid$ Core recovered - 80' Last casing - 4-1/2", $11.5 \mathrm{lb} / \mathrm{ft} @ 524^{\prime}$

\begin{tabular}{|c|c|c|c|c|}
\hline \multicolumn{5}{|c|}{ BITS -- Now drilling 3.89" hole } \\
\hline Bit number & Type 1 & Depth in, KB | I & Depth out, KB & | Footage \\
\hline 1 & $12-1 / 4 "$ tri-cone & $10^{\prime}$ & $12^{\prime}$ & 2 \\
\hline 2 & HQ impreg & $12^{\prime}$ & $172^{\prime}$ & 160 \\
\hline 3 & $8-1 / 2^{\prime \prime}$ tri-cone & $12^{\prime}$ & $176^{\prime}$ & 164 \\
\hline 4 & 6-1/4" impreg & $110^{\prime}$ (cement) & $225^{\prime}$ & 115 \\
\hline 5 & 6-1/4" impreg & $225^{\prime}$ & $462^{\prime}$ & 237 \\
\hline 6 & $6-1 / 4^{\prime \prime}$ impreg & $462^{\prime}$ & $525^{\prime}$ & 63 \\
\hline 7 & HQ impreg & $525^{\prime}$ (rock) & 673 & 148 \\
\hline 8 & HQ impreg & $673^{\prime}$ & 1149 & 476 \\
\hline 9 & HQ impreg & $1149^{\prime}$ & $1510^{\prime}$ & 361 \\
\hline 10 & HQ test bit & $1510^{\prime}$ & $1568^{\prime}$ & 58 \\
\hline 11 & HQ surf set & $1568^{\prime}$ & $1600^{\prime}$ & 32 \\
\hline 12 & HQ impreg & $1600^{\prime}$ & $1702^{\prime}$ & 102 \\
\hline 13 & HQ test bit & $1702^{\prime}$ & $1709^{\prime}$ & 7 \\
\hline 14 & HQ surf set & $1709^{\prime}$ & $1754^{\prime}$ & 45 \\
\hline 15 & HQ test bit & $1754^{\prime}$ & 1837 & 83 \\
\hline 16 & HQ impreg & 1837 & & \\
\hline
\end{tabular}

Drilling fluid - water, bentonite, polymer; soda ash

Flow rate - $25 \mathrm{gal} / \mathrm{min} \mid$ Pressure - psi $\mid$ Returns temp - n/a

$\mathrm{Wt}-8.4 \mathrm{lb} / \mathrm{gal}|\mathrm{Vis}-32 \mathrm{sec}| \mathrm{PV}-3 \mathrm{cP}\left|\mathrm{YP}-3 \mathrm{lb} / 100 \mathrm{ft}^{2}\right| \mathrm{pH}-8.5$

Lost circulation - no returns since fracture at $815^{\prime}$

Lithology of core logged since yesterday: [Summary - detailed log available]

None logged today

Summary of events last 24 hours:

Have been drilling ahead for the last 24 hours. Still experiencing some drillstring vibration, both high and low in the hole. Low rotary speeds $(\sim 100 \mathrm{rpm})$ have reduced vibration, but also penetration. Will continue trying combinations of rod lubricant and LCM.

Report by: John Finger 


\section{DAILY DRILLING REPORT - 08/17/93 \\ STEAMBOAT HILLS EXPLORATORY SLIMHOLE \\ Time of report - 0800}

Well number - SNLG 87-29| Location - SE 1/4, SE 1/4, Section 29, T18N, R20E, Washoe County, NV

Days since spud - $28 \mid$ Depth today - 2008' | Hole advance last $24 \mathrm{hr}-100^{\prime} \mid$ Core recovered - 100'

Last casing - 4-1/2", $11.5 \mathrm{lb} / \mathrm{ft} @ 524^{\prime}$

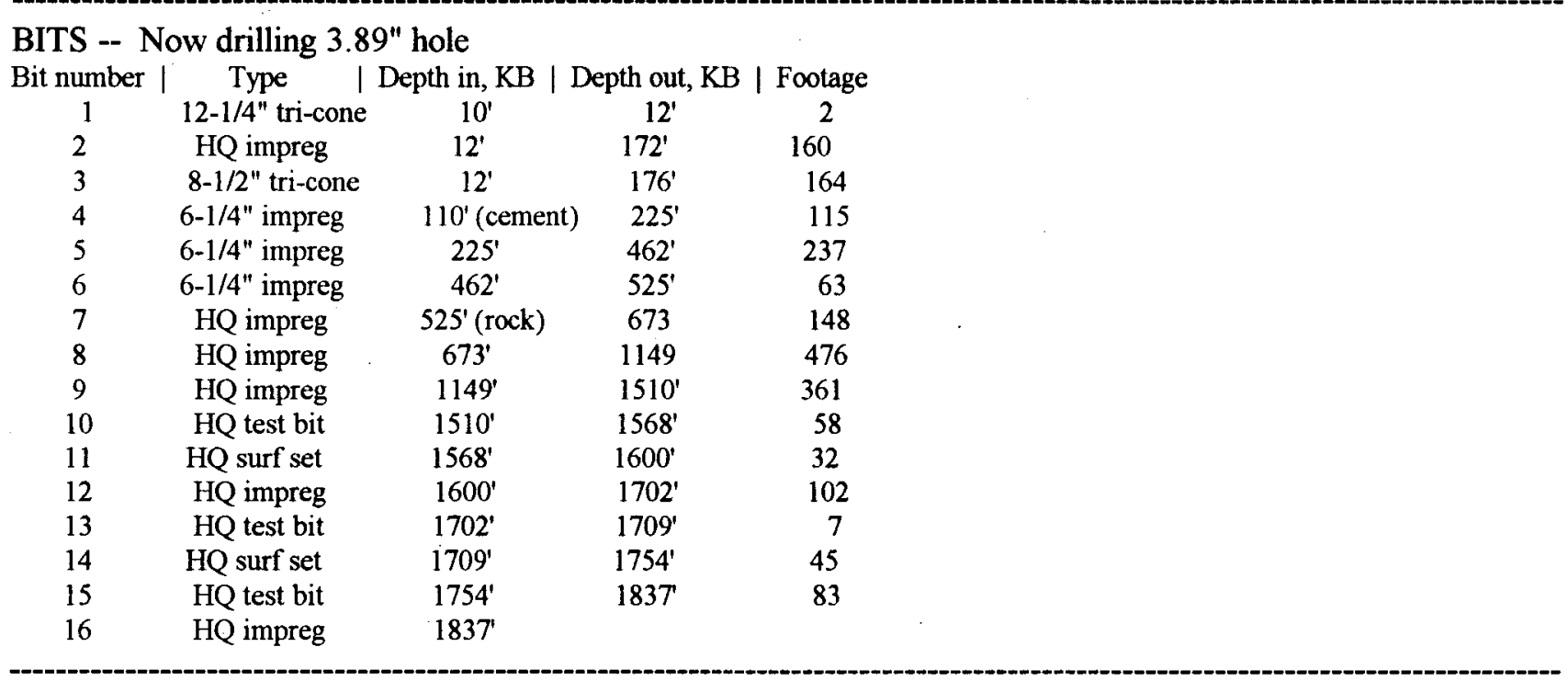

Drilling fluid - water, bentonite, polymer; soda ash

Flow rate $-25 \mathrm{gal} / \mathrm{min} \mid$ Pressure - psi $\mid$ Returns temp - n/a

Wt $-8.4 \mathrm{lb} / \mathrm{gal}|\mathrm{Vis}-32 \mathrm{sec}| \mathrm{PV}-3 \mathrm{cP}\left|\mathrm{YP}-3 \mathrm{lb} / 100 \mathrm{ft}^{2}\right| \mathrm{pH}-8.5$

Lost circulation - no returns since fracture at $815^{\prime}$

Lithology of core logged since yesterday: [Summary - detailed log available]

Core from $1745^{\prime}$ to $1819^{\prime}$, with the following features, is generally the same granodiorite as that previously described:

$1768^{\prime}-1770^{\prime}$ Moderately to heavily altered zone, with signifcant mechanical shear, open fractures at $60-90^{\circ}$

Summary of events last 24 hours:

Have been drilling ahead for the last 24 hours. Rate of penetration is reasonably good, with $100^{\prime}$ since yesterday. Bit wear is also better, with $170^{\prime+}$ on bit now in the hole. Current schedule is to drill through Wednesday night and begin rigging up for next series of production and injection tests at $\sim 0400$ Thursday. This will allow air-lifting to warm up the well before logging service company gets here. Will do production tests on Thursday, shut-in Thursday night, and injection tests on Friday. We will inject into both the open hole, at stepped injection rates, and into zones above and below a packer.

Deviation survey at $2000^{\prime}=1^{\circ}$.

Report by: John Finger 


\section{DAILY DRILLING REPORT - 08/18/93 \\ STEAMBOAT HILLS EXPLORATORY SLIMHOLE}

Time of report -0800

Well number - SNLG 87-29| Location - SE 1/4, SE 1/4, Section 29, T18N, R20E, Washoe County, NV

Days since spud - 29| Depth today - 2077' | Hole advance last $24 \mathrm{hr}-69^{\prime} \mid$ Core recovered - 68'

Last casing - 4-1/2", $11.5 \mathrm{lb} / \mathrm{ft} @ 524^{\prime}$

BITS -- Now drilling 3.89" hole

$\begin{array}{ccccc}\text { Bit number | } & \text { Type | } & \text { Depth in, KB } & \text { Depth out, KB } & \text { Footage } \\ 1 & 12-1 / 4^{\prime \prime} \text { tri-cone } & 10^{\prime} & 12^{\prime} & 2 \\ 2 & \text { HQ impreg } & 12^{\prime} & 172^{\prime} & 160 \\ 3 & 8-1 / 2^{\prime \prime} \text { tri-cone } & 12^{\prime} & 176^{\prime} & 164 \\ 4 & 6-1 / 4^{\prime \prime} \text { impreg } & 110^{\prime} \text { (cement) } & 225^{\prime} & 115 \\ 5 & 6-1 / 4^{\prime} \text { ' impreg } & 225^{\prime} & 462^{\prime} & 237 \\ 6 & 6-1 / 4^{\prime} \text { impreg } & 462^{\prime} & 525^{\prime} & 63 \\ 7 & \text { HQ impreg } & 525^{\prime} \text { (rock) } & 673 & 148 \\ 8 & \text { HQ impreg } & 673^{\prime} & 1149 & 476 \\ 9 & \text { HQ impreg } & 1149^{\prime} & 1510^{\prime} & 361 \\ 10 & \text { HQ test bit } & 1510^{\prime} & 1568^{\prime} & 58 \\ 11 & \text { HQ surf set } & 1568^{\prime} & 1600^{\prime} & 32 \\ 12 & \text { HQ impreg } & 1600^{\prime} & 1702^{\prime} & 102 \\ 13 & \text { HQ test bit } & 1702^{\prime} & 1709^{\prime} & 7 \\ 14 & \text { HQ surf set } & 1709^{\prime} & 1754^{\prime} & 45 \\ 15 & \text { HQ test bit } & 1754^{\prime} & 1837^{\prime} & 83 \\ 16 & \text { HQ impreg } & 1837^{\prime} & 2077^{\prime} & 240\end{array}$

Drilling fluid - water, bentonite, polymer; soda ash

Flow rate $-25 \mathrm{gal} / \mathrm{min} \mid$ Pressure - psi | Returns temp - $\mathrm{n} / \mathbf{a}$

$\mathrm{Wt}-8.4 \mathrm{lb} / \mathrm{gal}|\mathrm{Vis}-32 \mathrm{sec}| \mathrm{PV}-3 \mathrm{cP}\left|\mathrm{YP}-3 \mathrm{lb} / 100 \mathrm{ft}^{2}\right| \mathrm{pH}-8.5$

Lost circulation - no returns since fracture at $815^{\prime}$

Lithology of core logged since yesterday: [Summary - detailed log available]

No log today

Summary of events last 24 hours:

Drilled ahead until approximately 2100 yesterday. $\mathrm{POOH}$ for bit change; when back on bottom with new bit, drill string experienced heavy torque loads, enough to stall rotation. Drill rods either twisted off or were unscrewed by torque release; string is parted approximately $140^{\prime}$ off bottom. Driller sent wireline overshot down to retrieve core tube; overshot could not get back through pipe break, so pulled wireline out of overshot, leaving about $20^{\prime}$ of wire in the hole. Overshot is now either on top of stuck pipe or has fallen back into it. Running back in hole to tag top of fish and determine overshot location.

Report by: John Finger 


\section{DAILY DRILLING REPORT - 08/19/93 \\ STEAMBOAT HILLS EXPLORATORY SLIMHOLE \\ Time of report - 0800}

Well number - SNLG 87-29|Location - SE 1/4, SE 1/4, Section 29, T18N, R20E, Washoe County, NV

Days since spud - 30 | Depth today - 2077' | Hole advance last $24 \mathrm{hr}-0^{\prime} \mid$ Core recovered - $0^{\prime}$

Last casing - 4-1/2", $11.5 \mathrm{lb} / \mathrm{ft} @ 524^{\prime}$

\begin{tabular}{|c|c|c|c|c|}
\hline \multicolumn{5}{|c|}{ BITS -- Now drilling 3.89" hole } \\
\hline Bit number & Type & Depth in, KB | D & Depth out, KB & | Footage \\
\hline 1 & $12-1 / 4^{\prime \prime}$ tri-cone & $10^{\prime}$ & $12^{\prime}$ & 2 \\
\hline 2 & HQ impreg & $12^{\prime}$ & $172^{\prime}$ & 160 \\
\hline 3 & $8-1 / 2^{\prime \prime}$ tri-cone & $12^{\prime}$ & $176^{\prime}$ & 164 \\
\hline 4 & 6-1/4" impreg & $110^{\prime}$ (cement) & $225^{\prime}$ & 115 \\
\hline 5 & 6-1/4" impreg & $225^{\prime}$ & $462^{\prime}$ & 237 \\
\hline 6 & 6-1/4" impreg & $462^{\prime}$ & $525^{\prime}$ & 63 \\
\hline 7 & HQ impreg & $525^{\prime}$ (rock) & 673 & 148 \\
\hline 8 & HQ impreg & $673^{\prime}$ & 1149 & 476 \\
\hline 9 & HQ impreg & $1149^{\prime}$ & $1510^{\prime}$ & 361 \\
\hline 10 & HQ test bit & $1510^{\prime}$ & $1568^{\prime}$ & 58 \\
\hline 11 & HQ surf set & $1568^{\prime}$ & $1600^{\prime}$ & 32 \\
\hline 12 & HQ impreg & $1600^{\prime}$ & $1702^{\prime}$ & 102 \\
\hline 13 & HQ test bit & $1702^{\prime}$ & $1709^{\prime}$ & 7 \\
\hline 14 & HQ surf set & $1709^{\prime}$ & $1754^{\prime}$ & 45 \\
\hline 15 & HQ test bit & $1754^{\prime}$ & 1837 & 83 \\
\hline 16 & HQ impreg & 1837 & 2077 & 240 \\
\hline
\end{tabular}

Drilling fluid - water, bentonite, polymer; soda ash

Flow rate - xx gal/min $\mid$ Pressure - psi $\mid$ Returns temp - $\mathrm{n} / \mathbf{a}$

$\mathrm{Wt}-\mathrm{xxx} \mathrm{lb/gal|Vis} \mathrm{-} \mathrm{xx} \mathrm{sec}|\mathrm{PV}-\mathrm{x} \mathrm{cP}| \mathrm{YP}-\mathrm{x} \mathrm{lb} / 100 \mathrm{ft}^{2} \mid \mathrm{pH}-\mathrm{xxx}$

Lost circulation - no returns since fracture at $815^{\prime}$

Lithology of core logged since yesterday: [Summary - detailed log available]

Core from $1819^{\prime}$ to $2015^{\prime}$ is generally the same granodiorite previously described. There are fewer open fractures, none more than $3-5 \mathrm{~mm}$, and only one short $\left(1980^{\prime}-1985^{\prime}\right)$ zone of heavy alteration and mechanical shear.

Summary of events last 24 hours:

Have continued fishing for the last 24 hours. Used an inside swage to catch the inside of stuck pipe; pulled up approximately $10,000 \mathrm{lb}$ but pipe would not release. Suspect the fish is stuck at the bit. Went in the top of the drill pipe with an outside swage and tried to pick up the broken wireline, along with the overshot and possibly the inner core barrel. Retrieved wire and upper part of overshot; remainder of fish is still in hole. Will continue fishing to determine how much we can retrieve, then decide whether to sidetrack or mill up remainder.

Report by: John Finger 


\section{DAILY DRILLING REPORT - 08/20/93 \\ STEAMBOAT HILLS EXPLORATORY SLIMHOLE \\ Time of report -0800}

Well number - SNLG 87-29| Location - SE 1/4, SE 1/4, Section 29, T18N, R20E, Washoe County, NV

Days since spud - $31 \mid$ Depth today - 2077' | Hole advance last $24 \mathrm{hr}-0^{\prime} \mid$ Core recovered - 0'

Last casing - 4-1/2", $11.5 \mathrm{lb} / \mathrm{ft} @ 524^{\prime}$

\begin{tabular}{|c|c|c|c|c|}
\hline \multicolumn{5}{|c|}{ BITS -- Now drilling 3.89" hole } \\
\hline Bit number | & Type 1 & Depth in, KB & Depth out, KB & Footage \\
\hline 1 & $12-1 / 4 "$ tri-cone & $10^{\prime}$ & $12^{\prime}$ & 2 \\
\hline 2 & HQ impreg & $12^{\prime}$ & $172^{\prime}$ & 160 \\
\hline 3 & $8-1 / 2$ " tri-cone & $12^{\prime}$ & $176^{\prime}$ & 164 \\
\hline 4 & 6-1/4" impreg & $110^{\prime}$ (cement) & $225^{\prime}$ & 115 \\
\hline 5 & $6-1 / 4^{\prime \prime}$ impreg & $225^{\prime}$ & $462^{\prime}$ & 237 \\
\hline 6 & $6-1 / 4^{\prime \prime}$ impreg & $462^{\prime}$ & $525^{\prime}$ & 63 \\
\hline 7 & HQ impreg & $525^{\prime}$ (rock) & 673 & 148 \\
\hline 8 & HQ impreg & $673^{\prime}$ & 1149 & 476 \\
\hline 9 & HQ impreg & $1149^{\prime}$ & $1510^{\prime}$ & 361 \\
\hline 10 & HQ test bit & $1510^{\prime}$ & $1568^{\prime}$ & 58 \\
\hline 11 & HQ surf set & $1568^{\prime}$ & $1600^{\prime}$ & 32 \\
\hline 12 & HQ impreg & $1600^{\prime}$ & $1702^{\prime}$ & 102 \\
\hline 13 & HQ test bit & $1702^{\prime}$ & $1709^{\prime}$ & 7 \\
\hline 14 & HQ surf set & $1709^{\prime}$ & $1754^{\prime}$ & 45 \\
\hline 15 & HQ test bit & $1754^{\prime}$ & $1837^{\prime}$ & 83 \\
\hline 16 & HQ impreg & $1837^{\prime}$ & $2077^{\prime}$ & 240 \\
\hline
\end{tabular}

Drilling fluid - water, bentonite, polymer; soda ash

Flow rate - $\mathrm{xx}$ gal/min $\mid$ Pressure - $\mathrm{psi} \mid$ Returns temp - n/a

$\mathrm{Wt}$ - xxx lb/gal | Vis - xx sec | PV - x cP | YP - x lb/100ft ${ }^{2} \mid \mathrm{pH}-\mathrm{xxx}$

Lost circulation - no returns since fracture at $815^{\prime}$

Lithology of core logged since yesterday: [Summary - detailed log available]

No core logged

Summary of events last 24 hours:

Have continued fishing for the last 24 hours. Made several more trips inside stuck pipe with an outside swage and tried to pick up the overshot release, overshot and the inner core barrel. Got over the release but could not work it free. Went in with cutter and severed pipe at $2050 \mathrm{ft}$. Picked up inside swage and retrieved $126 \mathrm{ft}$ of drill pipe. Core barrel with $14 \mathrm{ft}$ of drill pipe still in hole. RIH with outside swage again and worked overshot and inner core barrel could not pull free. At report time running in hole with fishing service company spear and jars to work stuck core barrel. Have located wedge and drill off tools for side track if needed.

Report by: Ron Jacobson 


\section{DAILY DRILLING REPORT - 08/21/93 \\ STEAMBOAT HILLS EXPLORATORY SLIMHOLE \\ Time of report -0800}

Well number - SNLG 87-29 | Location - SE 1/4, SE 1/4, Section 29, T18N, R20E, Washoe County, NV

Days since spud $-32 \mid$ Depth today $-2118^{\prime} \mid$ Hole advance last $24 \mathrm{hr}-4 \mathrm{l}^{\prime} \mid$ Core recovered $-40^{\prime}$

Last casing - 4-1/2", $11.5 \mathrm{lb} / \mathrm{ft} @ 524^{\prime}$

\begin{tabular}{|c|c|c|c|c|}
\hline \multicolumn{5}{|c|}{ BITS -- Now drilling 3.89" hole } \\
\hline Bit number | & Type 1 & Depth in, $\mathrm{KB} \mid \mathrm{D}$ & Depth out, KB & Footage \\
\hline 1 & 12-1/4" tri-cone & $10^{\prime}$ & $12^{\prime}$ & 2 \\
\hline 2 & HQ impreg & $12^{\prime}$ & $172^{\prime}$ & 160 \\
\hline 3 & $8-1 / 2$ " tri-cone & $12^{\prime}$ & $176^{\prime}$ & 164 \\
\hline 4 & 6-1/4" impreg & $110^{\prime}$ (cement) & $225^{\prime}$ & 115 \\
\hline 5 & $6-1 / 4^{\prime \prime}$ impreg & $225^{\prime}$ & $462^{\prime}$. & 237 \\
\hline 6 & 6-1/4" impreg & $462^{\prime}$ & $525^{\prime}$ & 63 \\
\hline 7 & HQ impreg & $525^{\prime}$ (rock) & $673^{\prime}$ & 148 \\
\hline 8 & HQ impreg & $673^{\prime}$ & 1149 & 476 \\
\hline 9 & HQ impreg & $1149^{\prime}$ & $1510^{\prime}$ & 361 \\
\hline 10 & HQ test bit & $1510^{\prime}$ & $1568^{\prime}$ & 58 \\
\hline 11 & $\mathrm{HQ}$ surf set & $1568^{\prime}$ & $1600^{\prime}$ & 32 \\
\hline 12 & HQ impreg & $1600^{\prime}$ & $1702^{\prime}$ & 102 \\
\hline 13 & HQ test bit & $1702^{\prime}$ & $1709^{\prime}$ & 7 \\
\hline 14 & $\mathrm{HQ}$ surf set & $1709^{\prime}$ & $1754^{\prime}$ & 45 \\
\hline 15 & HQ test bit & $1754^{\prime}$ & 1837 & 83 \\
\hline 16 & HQ impreg & 1837 & 2077 & 240 \\
\hline 17 & HQ impreg & $2077^{\prime}$ & 2077 & 0 \\
\hline 18 & HQ impreg & 2077 & & \\
\hline
\end{tabular}

Drilling fluid - water, bentonite, polymer; soda ash

Flow rate - $20 \mathrm{gal} / \mathrm{min}$ | Pressure - 0 psi | Returns temp - $\mathrm{n} / \mathrm{a}$

$\mathrm{Wt}-\mathrm{n} / \mathrm{a}$ lb/gal | Vis - $37 \mathrm{sec}|\mathrm{PV}-\mathrm{x} \mathrm{cP}| \mathrm{YP}-\mathrm{x} \mathrm{lb} / 100 \mathrm{ft}^{2} \mid \mathrm{pH}-\mathbf{x x x}$

Lost circulation - no returns since fracture at $815^{\prime}$

Lithology of core logged since yesterday: [Summary - detailed log available]

No core logged

Summary of events last 24 hours:

Locked into fish with spear and jarred eight times before any movement. Jarred two more times and could pull up hole with $8,000 \mathrm{lb}$ over string weight. Continued pulling for $120 \mathrm{ft}$. while weight slacked off then no over pull. POOH without fish. RIH with swage and tagged fish $120 \mathrm{ft}$ off bottom. Pushed to bottom to tighten swage then POOH with fish. Recovered everything but overshot release. Bit is burned and missing two sections of matrix. Tube is severely sanded in. Upon investigation it looks as if the mica added to the drilling mud had exceptionally high sand content. This sanded in the tube reducing mud flow which burned the bit in. Ran temperature log then RIH with new bit and washed back to bottom. Back to coring by midnight. Not much fill in hole and release must be back in a crack. Recovered both missing bit segments on top of first core run. Coring ahead at report time with some vibration problems.

Report by: Ron Jacobson 


\section{DAILY DRILLING REPORT - 08/22/93 \\ STEAMBOAT HILLS EXPLORATORY SLIMHOLE}

Time of report - 0800

Well number - SNLG 87-29 | Location - SE 1/4, SE 1/4, Section 29, T18N, R20E, Washoe County, NV

Days since spud - 33 | Depth today - 2188' | Hole advance last $24 \mathrm{hr}-70^{\prime} \mid$ Core recovered - 70'

Last casing - 4-1/2", $11.5 \mathrm{lb} / \mathrm{ft} @ 524^{\prime}$

\begin{tabular}{c|cccc}
\multicolumn{6}{c}{ BITS -- Now drilling 3.89" hole } & & \\
Bit number & \multicolumn{2}{c}{ Type } & | Depth in, KB | & Depth out, KB |. Footage \\
1 & $12-1 / 4^{\prime \prime}$ tri-cone & $10^{\prime}$ & $12^{\prime}$ & 2 \\
2 & HQ impreg & $12^{\prime}$ & $172^{\prime}$ & 160 \\
3 & $8-1 / 2^{\prime \prime}$ tri-cone & $12^{\prime}$ & $176^{\prime}$ & 164 \\
4 & $6-1 / 4^{\prime \prime}$ impreg & $110^{\prime}$ (cement) & $225^{\prime}$ & 115 \\
5 & $6-1 / 4^{\prime \prime}$ impreg & $225^{\prime}$ & $462^{\prime}$ & 237 \\
6 & $6-1 / 4^{\prime \prime}$ impreg & $462^{\prime}$ & $525^{\prime}$ & 63 \\
7 & HQ impreg & $525^{\prime}$ (rock) & $673^{\prime}$ & 148 \\
8 & HQ impreg & $673^{\prime}$ & 1149 & 476 \\
9 & HQ impreg & $1149^{\prime}$ & $1510^{\prime}$ & 361 \\
10 & HQ test bit & $1510^{\prime}$ & $1568^{\prime}$ & 58 \\
11 & HQ surf set & $1568^{\prime}$ & $1600^{\prime}$ & 32 \\
12 & HQ impreg & $1600^{\prime}$ & $1702^{\prime}$ & 102 \\
13 & HQ test bit & $1702^{\prime}$ & $1709^{\prime}$ & 7 \\
14 & HQ surf set & $1709^{\prime}$ & $1754^{\prime}$ & 45 \\
15 & HQ test bit & $1754^{\prime}$ & $1837^{\prime}$ & 83 \\
16 & HQ impreg & $1837^{\prime}$ & $2077^{\prime}$ & 240 \\
17 & HQ impreg & $2077^{\prime}$ & $2077^{\prime}$ & 0 \\
18 & HQ impreg & $207^{\prime}$ & 2168 & 91 \\
19 & HQ impreg & $2168^{\prime}$ & &
\end{tabular}

Drilling fluid - water, bentonite, polymer; soda ash

Flow rate $-20 \mathrm{gal} / \mathrm{min} \mid$ Pressure - $0 \mathrm{psi} \mid$ Returns temp - $\mathrm{n} / \mathrm{a}$

$\mathrm{Wt}-\mathrm{n} / \mathrm{a} \mathrm{lb} / \mathrm{gal}|\mathrm{Vis}-37 \mathrm{sec}| \mathrm{PV}-\mathrm{x} \mathrm{cP}\left|\mathrm{YP}-\mathrm{x} \mathrm{lb} / 100 \mathrm{ft}^{2}\right| \mathrm{pH}-\mathrm{xxx}$

Lost circulation - no returns since fracture at $815^{\prime}$

Lithology of core logged since yesterday: [Summary - detailed log available]

Core from $2015^{\prime}$ to $2068^{\prime}$ is generally the same granodiorite previously described. No open fractures greater than $5 \mathrm{~mm}$.

Summary of events last 24 hours:

Core ahead to $2168^{\prime}$ then trip for bit change. Drilled through one heavily fractured zone and had to redrill cave from this zone. Stuck inner tube at report time, will have to trip to recover tube.

Report by: Ron Jacobson 


\section{DAILY DRILLING REPORT - 08/23/93 \\ STEAMBOAT HILLS EXPLORATORY SLIMHOLE \\ Time of report - 0800}

Well number - SNLG 87-29 | Location - SE 1/4, SE 1/4, Section 29, T18N, R20E, Washoe County, NV

Days since spud - 34 | Depth today - 2238' Hole advance last $24 \mathrm{hr}-50^{\prime} \mid$ Core recovered - 50'

Last casing - 4-1/2", $11.5 \mathrm{lb} / \mathrm{ft} @$ (524'

\begin{tabular}{|c|c|c|c|c|}
\hline \multicolumn{5}{|c|}{ BITS -- Now drilling 3.89" hole } \\
\hline Bit number & Type | I & Depth in, KB | D & Depth out, KB & | Footage \\
\hline 1 & 12-1/4" tri-cone & $10^{\prime}$ & $12^{\prime}$ & 2 \\
\hline 2 & HQ impreg-S2 & $12^{\prime}$ & $172^{\prime}$ & 160 \\
\hline 3 & $8-1 / 2 "$ tri-cone & $12^{\prime}$ & $176^{\circ}$ & 164 \\
\hline 4 & 6-1/4" impreg-S2 & $110^{\prime}$ (cement) & $225^{\prime}$ & 115 \\
\hline 5 & 6-1/4" impreg-S8 & $225^{\prime}$ & $462^{\prime}$ & 237 \\
\hline 6 & 6-1/4" impreg-S8 & $462^{\prime}$ & $525^{\prime}$ & 63 \\
\hline $2 \mathrm{RR}$ & HQ impreg-S2 & $525^{\prime}$ (rock) & $673^{\prime}$ & 148 \\
\hline 7 & HQ impreg-S7 & 673 & 1149 & 476 \\
\hline 8 & HQ impreg-S8 & $1149^{\prime}$ & $1510^{\prime}$ & 361 \\
\hline 9 & HQ impreg-S5 & $1510^{\prime}$ & $1568^{\prime}$ & 58 \\
\hline 10 & HQ surf set & $1568^{\prime}$ & $1600^{\prime}$ & 32 \\
\hline 11 & HQ impreg-S7 & $1600^{\prime}$ & $1702^{\prime}$ & 102 \\
\hline 12 & HQ impreg-S5 & $1702^{\prime}$ & $1709^{\prime}$ & 7 \\
\hline 13 & HQ surf set & $1709^{\prime}$ & $1754^{\prime}$ & 45 \\
\hline 14 & HQ impreg-S5 & $1754^{\prime}$ & 1837 & 83 \\
\hline 15 & HQ impreg-S7 & $1837^{\prime}$ & 2077 & 240 \\
\hline 16 & HQ impreg-S7 & $2077^{\prime}$ & $2077^{\prime}$ & 0 \\
\hline 17 & HQ impreg-S7 & $2077^{\prime}$ & 2168 & 91 \\
\hline 18 & HQ impreg-S8 & $2168^{\prime}$ & & \\
\hline
\end{tabular}

Drilling fluid - water, bentonite, polymer; soda ash, torkease

Flow rate $-20 \mathrm{gal} / \mathrm{min} \mid$ Pressure - 0 psi | Returns temp - $\mathrm{n} / \mathrm{a}$

$\mathrm{Wt}-8.4 \mathrm{lb} / \mathrm{gal}|\mathrm{Vis}-32 \mathrm{sec}| \mathrm{PV}-3 \mathrm{cP}\left|\mathrm{YP}-2 \mathrm{lb} / 100 \mathrm{ft}^{2}\right| \mathrm{pH}-8.5$

Lost circulation - no returns since fracture at $815^{\prime}-$

Lithology of core logged since yesterday: [Summary - detailed log available]

No core logged.

Summary of events last 24 hours:

Had two trips, one for a stuck inner tube caused by loose roll pin and the other for high water pressure and vibration. Greased rods on trip back in. Rotation speed up and torque down, drilling good.

Report by: Ron Jacobson 


\section{DAILY DRILLING REPORT - 08/24/93 \\ STEAMBOAT HILLS EXPLORATORY SLIMHOLE \\ Time of report -0800}

Well number - SNLG 87-29 | Location - SE 1/4, SE 1/4, Section 29, T18N, R20E, Washoe County, NV

Days since spud - 35 | Depth today - 2298' | Hole advance last $24 \mathrm{hr}-60^{\prime} \mid$ Core recovered - $60^{\prime}$

Last casing - 4-1/2", $11.5 \mathrm{lb} / \mathrm{ft} @ 524^{\prime}$

\begin{tabular}{|c|c|c|c|c|}
\hline \multicolumn{5}{|c|}{ BITS -- Now drilling 3.89" hole } \\
\hline Bit number | & Type $\quad 1$ & Depth in, $\mathrm{KB}$ | & Depth out, KB & | Footage \\
\hline 1 & $12-1 / 4^{\prime \prime}$ tri-cone & $10^{\prime}$ & $12^{\prime}$ & 2 \\
\hline 2 & HQ impreg-S2 & $12^{\prime}$ & $172^{\prime}$ & 160 \\
\hline 3 & $8-1 / 2^{\prime \prime}$ tri-cone & $12^{\prime}$ & $176^{\prime}$ & 164 \\
\hline 4 & 6-1/4" impreg-S2 & $110^{\prime}$ (cement) & $225^{\prime}$ & 115 \\
\hline 5 & 6-1/4" impreg-S8 & $225^{\prime}$ & $462^{\prime}$ & 237 \\
\hline 6 & 6-1/4" impreg-S8 & $462^{\prime}$ & 525 & 63 \\
\hline 2RR & HQ impreg-S2 & $525^{\prime}$ (rock) & $673^{\prime}$ & 148 \\
\hline 7 & HQ impreg-S7 & $673^{\prime}$ & 1149 & 476 \\
\hline 8 & HQ impreg-S8 & $1149^{\prime}$ & $1510^{\prime}$ & 361 \\
\hline 9 & HQ impreg-S5 & $1510^{\prime}$ & $1568^{\prime}$ & 58 \\
\hline 10 & HQ surf set & $1568^{\prime}$ & $1600^{\prime}$ & 32 \\
\hline 11 & HQ impreg-S7 & $1600^{\prime}$ & $1702^{\prime}$ & 102 \\
\hline 12 & HQ impreg-S5 & $1702^{\prime}$ & $1709^{\prime}$ & 7 \\
\hline 13 & HQ surf set & $1709^{\prime}$ & $1754^{\prime}$ & 45 \\
\hline 14 & HQ impreg-S5 & $1754^{\prime}$ & 1837 & 83 \\
\hline 15 & HQ impreg-S7 & 1837 & 2077 & 240 \\
\hline 16 & HQ impreg-S7 & $2077^{\prime}$ & $2077^{\prime}$ & 0 \\
\hline 17 & HQ impreg-S7 & $2077^{\prime}$ & 2168 & 91 \\
\hline 18 & HQ impreg-S8 & $2168^{\prime}$ & & \\
\hline
\end{tabular}

Drilling fluid - water, bentonite, polymer; soda ash, torkease

Flow rate $-20 \mathrm{gal} / \mathrm{min} \mid$ Pressure - 0 psi | Returns temp - $\mathrm{n} / \mathrm{a}$

$\mathrm{Wt}-8.4 \mathrm{lb} / \mathrm{gal}|\mathrm{Vis}-32 \mathrm{sec}| \mathrm{PV}-3 \mathrm{cP}\left|\mathrm{YP}-2 \mathrm{lb} / 100 \mathrm{ft}^{2}\right| \mathrm{pH}-8.5$

Lost circulation - no returns since fracture at $815^{\prime}-$ -

Lithology of core logged since yesterday: [Summary - detailed log available]

2070.4 to 2186 logged. Heavily altered highly fractured zone from 2132.9 to 2144.7 .

Summary of events last 24 hours:

Continued vibration problems. Trying to find backside lubricants that will withstand the temperature. Have had some success with rod grease but it doesn't stay long enough. Made three short and one full trip to condition hole. Rotation speed up and torque down after trips.

Report by: Ron Jacobson 


\section{DAILY DRILLING REPORT - 08/25/93 \\ STEAMBOAT HILLS EXPLORATORY SLIMHOLE \\ Time of report -0800}

Well number - SNLG 87-29| Location - SE 1/4, SE 1/4, Section 29, T18N, R20E, Washoe County, NV

Days since spud - 36 | Depth today - 2388' | Hole advance last $24 \mathrm{hr}-90^{\prime} \mid$ Core recovered - 90' Last casing - 4-1/2", $11.5 \mathrm{lb} / \mathrm{ft} @ 524^{\prime}$

\begin{tabular}{l|cccc}
\multicolumn{6}{c}{ BITS -- Now drilling 3.89" hole } & & \\
Bit number & Type & Depth in, KB | & Depth out, KB | Footage \\
1 & $12-1 / 4^{\prime \prime}$ tri-cone & $10^{\prime}$ & $12^{\prime}$ & 2 \\
2 & HQ impreg-S2 & $12^{\prime}$ & $172^{\prime}$ & 160 \\
3 & $8-1 / 2^{\prime \prime}$ tri-cone & $12^{\prime}$ & $176^{\prime}$ & 164 \\
4 & $6-1 / 4^{\prime \prime}$ impreg-S2 & $110^{\prime}$ (cement) & $225^{\prime}$ & 115 \\
5 & $6-1 / 4^{\prime \prime}$ impreg-S8 & $225^{\prime}$ & $462^{\prime}$ & 237 \\
6 & $6-1 / 4^{\prime \prime}$ impreg-S8 & $462^{\prime}$ & $525^{\prime}$ & 63 \\
$2 \mathrm{RR}$ & HQ impreg-S2 & $525^{\prime}$ (rock) & $673^{\prime}$ & 148 \\
7 & HQ impreg-S7 & $673^{\prime}$ & 1149 & 476 \\
8 & HQ impreg-S8 & $1149^{\prime}$ & $1510^{\prime}$ & 361 \\
9 & HQ impreg-S5 & $1510^{\prime}$ & $1568^{\prime}$ & 58 \\
10 & HQ surf set & $1568^{\prime}$ & $1600^{\prime}$ & 32 \\
11 & HQ impreg-S7 & $1600^{\prime}$ & $1702^{\prime}$ & 102 \\
12 & HQ impreg-S5 & $1702^{\prime}$ & $1709^{\prime}$ & 7 \\
13 & HQ surf set & $1709^{\prime}$ & $1754^{\prime}$ & 45 \\
14 & HQ impreg-S5 & $1754^{\prime}$ & $1837^{\prime}$ & 83 \\
15 & HQ impreg-S7 & $1837^{\prime}$ & $2077^{\prime}$ & 240 \\
16 & HQ impreg-S7 & $2077^{\prime}$ & $2077^{\prime}$ & 0 \\
17 & HQ impreg-S7 & $2077^{\prime}$ & 2168 & 91 \\
18 & HQ impreg-S8 & $2168^{\prime}$ & &
\end{tabular}

Drilling fluid - water, bentonite, polymer; soda ash, torkease

Flow rate $-20 \mathrm{gal} / \mathrm{min}$ | Pressure - 0 psi | Returns temp - n/a

Wt $-8.4 \mathrm{lb} / \mathrm{gal}$ | Vis - $33 \mathrm{sec}$ | PV $-3 \mathrm{cP}$ |YP $-2 \mathrm{lb} / 100 \mathrm{ft}^{2} \mid \mathrm{pH}-8.0$

Lost circulation - no returns since fracture at $815^{\prime}-$ -

Lithology of core logged since yesterday: [Summary - detailed log available]

No new core log report.

Summary of events last 24 hours:

Cored ahead with no trips. Going a little slow but going good. No down hole vibrations since greasing all the drill rods with rod grease loaded with torkease. BHT 316 deg. F.

Report by: Ron Jacobson 


\section{DAILY DRILLING REPORT - 08/26/93 \\ STEAMBOAT HILLS EXPLORATORY SLIMHOLE \\ Time of report -0800}

Well number - SNLG 87-29 | Location - SE 1/4, SE 1/4, Section 29, T18N, R20E, Washoe County, NV

Days since spud - 37| Depth today - 2348' | Hole advance last $24 \mathrm{hr}-60^{\prime} \mid$ Core recovered - 60'

Last casing - 4-1/2", $11.5 \mathrm{lb} / \mathrm{ft} @$ (a) 524'

\begin{tabular}{|c|c|c|c|c|}
\hline \multicolumn{5}{|c|}{ BITS -- Now drilling 3.89" hole } \\
\hline Bit number & | Type | & Depth in, KB । & Depth out, KB & | Footage \\
\hline 1 & $12-1 / 4^{\prime \prime}$ tri-cone & $10^{\prime}$ & $12^{\prime}$ & 2 \\
\hline 2 & HQ impreg-S2 & $12^{\prime}$ & $172^{\prime}$ & 160 \\
\hline 3 & $8-1 / 2$ " tri-cone & $12^{\prime}$ & $176^{\prime}$ & 164 \\
\hline 4 & BSF impreg-S2 & $110^{\prime}$ (cement) & $225^{\prime}$ & 115 \\
\hline 5 & BSF impreg-S8 & $225^{\prime}$ & $462^{\prime}$ & 237 \\
\hline 6 & BSF impreg-S8 & $462^{\prime}$ & $525^{\prime}$ & 63 \\
\hline 2RR & HQ impreg-S2 & $525^{\prime}$ (rock) & $673^{\prime}$ & 148 \\
\hline 7 & HQ impreg-S7 & $673^{\prime}$ & 1149 & 476 \\
\hline 8 & HQ impreg-S8 & $1149^{\prime}$ & $1510^{\prime}$ & 361 \\
\hline 9 & HQ impreg-S5 & $1510^{\prime}$ & $1568^{\prime}$ & 58 \\
\hline 10 & HQ surf set & $1568^{\prime}$ & $1600^{\prime}$ & 32 \\
\hline 11 & HQ impreg-S7 & $1600^{\prime}$ & $1702^{\prime}$ & 102 \\
\hline 12 & HQ impreg-S5 & $1702^{\prime}$ & $1709^{\prime}$ & 7 \\
\hline 13 & HQ surf set & $1709^{\prime}$ & $1754^{\prime}$ & 45 \\
\hline 14 & HQ impreg-S5 & $1754^{\prime}$ & $1837^{\prime}$ & 83 \\
\hline 15 & HQ impreg-S7 & $1837^{\prime}$ & $2077^{\prime}$ & 240 \\
\hline 16 & HQ impreg-S7 & 2077 & 2077 & 0 \\
\hline 17 & HQ impreg-S7 & 2077 & $2168^{\prime}$ & 91 \\
\hline 18 & HQ impreg-S8 & $2168^{\prime}$ & $2426^{\prime}$ & 258 \\
\hline 19 & HQ impreg-S9 & $2426^{\prime}$ & 2437 & 11 \\
\hline 20 & HQ impreg-S7 & 2437 & & \\
\hline
\end{tabular}

Drilling fluid - water, bentonite, polymer; soda ash, torkease

Flow rate $-17 \mathrm{gal} / \mathrm{min}$ | Pressure - 0 psi | Returns temp - n/a

$\mathrm{Wt}-8.4 \mathrm{lb} / \mathrm{gal}|\mathrm{Vis}-33 \mathrm{sec}| \mathrm{PV}-3 \mathrm{cP}\left|\mathrm{YP}-2 \mathrm{lb} / 100 \mathrm{ft}^{2}\right| \mathrm{pH}-8.0$

Lost circulation - no returns since fracture at $815^{\prime}-$ -

Lithology of core logged since yesterday: [Summary - detailed log available]

Core logged from 2182 to $2388^{\prime}$. Still mostly the same granodiorite previously described. Very few open fractures none over $3 \mathrm{~mm}$.

Summary of events last 24 hours:

Bit went at 2426'. POOH and RIH with series 9 bit. It would not cut so tripped out to try another series 7 bit. Greased rods on trip. BHT $318 \mathrm{deg}$ F. at $2358^{\prime}$ and $315 \mathrm{deg}$ F at $2408^{\prime}$. Drilling ahead with at report time with no vibration problems.

Report by: Ron Jacobson 


\section{DAILY DRILLING REPORT - 08/27/93 \\ STEAMBOAT HILLS EXPLORATORY SLIMHOLE}

Time of report -0800

Well number - SNLG 87-29| Location - SE 1/4, SE 1/4, Section 29, T18N, R20E, Washoe County, NV

Days since spud - $38 \mid$ Depth today - 2538' | Hole advance last $24 \mathrm{hr}-90^{\prime} \mid$ Core recovered - 90'

Last casing - 4-1/2", $11.5 \mathrm{lb} / \mathrm{ft} @ 524$ '

\begin{tabular}{|c|c|c|c|c|}
\hline \multicolumn{5}{|c|}{ BITS -- Now drilling 3.89" hole } \\
\hline Bit number & | Type $\mid$ & Depth in, $\mathrm{KB}$ | & Depth out, KB & Footage \\
\hline 1 & $12-1 / 4 "$ tri-cone & $10^{\prime}$ & $12^{\prime}$ & 2 \\
\hline 2 & HQ impreg-S2 & $12^{\prime}$ & $172^{\prime}$ & 160 \\
\hline 3 & $8-1 / 2^{\prime \prime}$ tri-cone & $12^{\prime}$ & $176^{\prime}$ & 164 \\
\hline 4 & BSF impreg-S2 & $110^{\prime}$ (cement) & $225^{\prime}$ & 115 \\
\hline 5 & BSF impreg-S8 & 225 & $462^{\prime}$ & 237 \\
\hline 6 & BSF impreg-S8 & $462^{\prime}$ & $525^{\prime}$ & 63 \\
\hline 2RR & HQ impreg-S2 & $525^{\prime}$ (rock) & $673^{\prime}$ & 148 \\
\hline 7 & HQ impreg-S7 & $673^{\prime}$ & 1149 & 476 \\
\hline 8 & HQ impreg-S8 & $1149^{\prime}$ & $1510^{\prime}$ & 361 \\
\hline 9 & HQ impreg-S5 & $1510^{\prime}$ & $1568^{\prime}$ & 58 \\
\hline 10 & HQ surf set & 1568 & $1600^{\prime}$ & 32 \\
\hline 11 & HQ impreg-S7 & $1600^{\prime}$ & $1702^{\prime}$ & 102 \\
\hline 12 & HQ impreg-S5 & $1702^{\prime}$ & $1709^{\prime}$ & 7 \\
\hline 13 & HQ surf set & $1709^{\prime}$ & $1754^{\prime}$ & 45 \\
\hline 14 & HQ impreg-S5 & $1754^{\prime}$ & $1837^{\prime}$ & 83 \\
\hline 15 & HQ impreg-S7 & $1837^{\prime}$ & 2077 & 240 \\
\hline 16 & HQ impreg-S7 & $2077^{\prime}$ & $2077^{\prime}$ & 0 \\
\hline 17 & HQ impreg-S7 & 2077 & $2168^{\prime}$ & 91 \\
\hline 18 & HQ impreg-S8 & $2168^{\prime}$ & $2426^{\prime}$ & 258 \\
\hline 19 & HQ impreg-S9 & $2426^{\prime}$ & 2437 & 11 \\
\hline 20 & HQ impreg-S7 & 2437 & & \\
\hline
\end{tabular}

Drilling fluid - water, bentonite, polymer; soda ash, torkease

Flow rate $-17 \mathrm{gal} / \mathrm{min}$ | Pressure - $0 \mathrm{psi}$ | Returns temp - $\mathrm{n} / \mathrm{a}$

$\mathrm{Wt}-8.4 \mathrm{lb} / \mathrm{gal}|\mathrm{Vis}-33 \mathrm{sec}| \mathrm{PV}-4 \mathrm{cP}\left|\mathrm{YP}-3 \mathrm{lb} / 100 \mathrm{ft}^{2}\right| \mathrm{pH}-9.0$

Lost circulation - no returns since fracture at $815^{\prime}-$ -

Lithology of core logged since yesterday: [Summary - detailed log available]

No core logged.

Summary of events last 24 hours:

Drilling ahead last 24 hours. ROP a little slow but going OK. Bore hole deviation at $2500^{\prime}$ is 2 deg. Replaced core retrieval wire line.

Report by: Ron Jacobson 


\section{DAILY DRILLING REPORT - 08/28/93 \\ STEAMBOAT HILLS EXPLORATORY SLIMHOLE}

Time of report -0800

Well number - SNLG 87-29| Location - SE 1/4, SE 1/4, Section 29, T18N, R20E, Washoe County, NV

Days since spud - 39 | Depth today - 2624' | Hole advance last $24 \mathrm{hr}-86^{\prime} \mid$ Core recovered - 86'

Last casing - 4-1/2", $11.5 \mathrm{lb} / \mathrm{ft} @ 524^{\prime}$

\begin{tabular}{|c|c|c|c|c|}
\hline \multicolumn{5}{|c|}{ BITS -- Now drilling 3.89" hole } \\
\hline Bit number & Type $\quad$ | & | Depth in, KB | & Depth out, KB & | Footage \\
\hline 1 & 12-1/4" tri-cone & $10^{\prime}$ & $12^{\prime}$ & 2 \\
\hline 2 & HQ impreg-S2 & $12^{\prime}$ & $172^{\prime}$ & 160 \\
\hline 3 & $8-1 / 2 "$ tri-cone & $12^{\prime}$ & $176^{\prime}$ & 164 \\
\hline 4 & BSF impreg-S2 & $110^{\prime}$ (cement) & $225^{\prime}$ & 115 \\
\hline 5 & BSF impreg-S8 & $225^{\prime}$ & $462^{\prime}$ & 237 \\
\hline 6 & BSF impreg-S8 & $462^{\prime}$ & $525^{\prime}$ & 63 \\
\hline 2RR & HQ impreg-S2 & $525^{\prime}$ (rock) & 673 & 148 \\
\hline 7 & HQ impreg-S7 & $673^{\prime}$ & 1149 & 476 \\
\hline 8 & HQ impreg-S8 & $1149^{\prime}$ & $1510^{\prime}$ & 61 \\
\hline 9 & HQ impreg-S5 & $1510^{\prime}$ & $1568^{\prime}$ & 58 \\
\hline 10 & $\mathrm{HQ}$ surf set & $1568^{\prime}$ & $1600^{\prime}$ & 32 \\
\hline 11 & HQ impreg-S7 & $1600^{\prime}$ & $1702^{\prime}$ & 102 \\
\hline 12 & HQ impreg-S5 & $1702^{\prime}$ & $1709^{\prime}$ & 7 \\
\hline 13 & HQ surf set & $1709^{\prime}$ & $1754^{\prime}$ & 45 \\
\hline 14 & $\mathrm{HQ}$ impreg-S5 & $1754^{\prime}$ & $1837^{\prime}$ & 83 \\
\hline 15 & HQ impreg-S7 & $1837^{*}$ & $2077^{\prime}$ & 240 \\
\hline 16 & HQ impreg-S7 & $2077^{\prime}$ & 2077 & 0 \\
\hline 17 & HQ impreg-S7 & $2077^{\prime}$ & $2168^{\prime}$ & 91 \\
\hline 18 & HQ impreg-S8 & $2168^{\prime}$ & $2426^{\prime}$ & 258 \\
\hline 19 & HQ impreg-S9 & $2426^{\prime}$ & $2437^{\prime}$ & 11 \\
\hline 20 & HQ impreg-S7 & $2437^{\prime}$ & $2624^{\prime}$ & 187 \\
\hline 21 & HQ impreg-S7S & $2624^{\prime}$ & & \\
\hline
\end{tabular}

Drilling fluid - water, bentonite, polymer; soda ash, torkease

Flow rate $-17 \mathrm{gal} / \mathrm{min} \mid$ Pressure - 0 psi | Returns temp - $\mathrm{n} / \mathrm{a}$

$\mathrm{Wt}-8.4 \mathrm{lb} / \mathrm{gal}|\mathrm{Vis}-33 \mathrm{sec}| \mathrm{PV}-4 \mathrm{cP}\left|\mathrm{YP}-3 \mathrm{lb} / 100 \mathrm{ft}^{2}\right| \mathrm{pH}-9.0$

Lost circulation - no returns since fracture at 815 '--

Lithology of core logged since yesterday: [Summary - detailed log available]

Core $\log$ received from 2388 to $2538^{\prime}$. Mostly weak to unaltered granodiorite with no open fractures $>1 \mathrm{~mm}$ logged.

Summary of events last 24 hours:

ROP slowing, having trouble stripping bit. Vibrations and torque back at 2598', pull back 32 stands and grease. ROP improves in more broken rock. Torque up and bit goes at 2624.8'. At time of report making up 20' core barrel with new special series 7 bit built with geosets for gage protection and lower diamond concentration. It is hoped this will allow the bit to strip better and hold gage longer. Last BHT at $2608^{\prime}$ is $315 \mathrm{deg}$. F.

Report by: Ron Jacobson 


\section{DAILY DRILLING REPORT - 08/29/93 \\ STEAMBOAT HILLS EXPLORATORY SLIMHOLE \\ Time of report -0800}

Well number - SNLG 87-29 | Location - SE 1/4, SE 1/4, Section 29, T18N, R20E, Washoe County, NV

Days since spud - 40 | Depth today - 2720' | Hole advance last $24 \mathrm{hr}-96^{\prime} \mid$ Core recovered - 96'

Last casing-4-1/2", $11.5 \mathrm{lb} / \mathrm{ft} @$, 524'

\begin{tabular}{|c|c|c|c|c|}
\hline \multicolumn{5}{|c|}{ BITS -- Now drilling 3.89" hole } \\
\hline Bit number & | Type $\quad$ | & Depth in, KB & Depth out, KB & | Footage \\
\hline 1 & $12-1 / 4^{\prime \prime}$ tri-cone & $10^{\prime}$ & $12^{\prime}$ & 2 \\
\hline 2 & HQ impreg-S2 & $12^{\prime}$ & $172^{\prime}$ & 160 \\
\hline 3 & $8-1 / 2$ " tri-cone & $12^{\prime}$ & $176^{\prime}$ & 164 \\
\hline 4 & BSF impreg-S2 & $110^{\prime}$ (cement) & $225^{\prime}$ & 115 \\
\hline 5 & BSF impreg-S8 & $225^{\prime}$ & $462^{\prime}$ & 237 \\
\hline 6 & BSF impreg-S8 & $462^{\prime}$ & $525^{\prime}$ & 63 \\
\hline 2RR & HQ impreg-S2 & $525^{\prime}$ (rock) & $673^{\prime}$ & 148 \\
\hline 7 & HQ impreg-S7 & $673^{\prime}$ & 1149 & 476 \\
\hline 8 & HQ impreg-S8 & $1149^{\prime}$ & $1510^{\prime}$ & 61 \\
\hline 9 & HQ impreg-S5 & $1510^{\prime}$ & $1568^{\prime}$ & 58 \\
\hline 10 & HQ surf set & $1568^{\prime}$ & $1600^{\prime}$ & 32 \\
\hline 11 & HQ impreg-S7 & $1600^{\prime}$ & $1702^{\prime}$ & 102 \\
\hline 12 & HQ impreg-S5 & $1702^{\prime}$ & $1709^{\prime}$ & 7 \\
\hline 13 & HQ surf set & $1709^{\prime}$ & $1754^{\prime}$ & 45 \\
\hline 14 & HQ impreg-S5 & $1754^{\prime}$ & 1837 & 83 \\
\hline 15 & HQ impreg-S7 & $1837^{\prime}$ & $2077^{\prime}$ & 240 \\
\hline 16 & HQ impreg-S7 & $2077^{\prime}$ & $2077^{\prime}$ & 0 \\
\hline 17 & HQ impreg-S7 & $2077^{\prime}$ & $2168^{\prime}$ & 91 \\
\hline 18 & HQ impreg-S8 & $2168^{\prime}$ & $2426^{\prime}$ & 258 \\
\hline 19 & HQ impreg-S9 & $2426^{\prime}$ & 2437 & 11 \\
\hline 20 & HQ impreg-s7 & 2437 & $2624^{\prime}$ & 187 \\
\hline 21 & $\mathrm{HQ}$ impreg-S7S & $2624^{\prime}$ & & \\
\hline
\end{tabular}

Drilling fluid - water, bentonite, polymer; soda ash, torkease

Flow rate $-17 \mathrm{gal} / \mathrm{min} \mid$ Pressure - 0 psi $\mid$ Returns temp - $\mathbf{n} / \mathbf{a}$

$\mathrm{Wt}-8.4 \mathrm{lb} / \mathrm{gal}|\mathrm{Vis}-32 \mathrm{sec}| \mathrm{PV}-3 \mathrm{cP}\left|\mathrm{YP}-3 \mathrm{lb} / 100 \mathrm{ft}^{2}\right| \mathrm{pH}-9.0$

Lost circulation - no returns since fracture at $815^{\prime}-$ -

Lithology of core logged since yesterday: [Summary - detailed log available]

No core log received at report time.

Summary of events last 24 hours:

Drilling ahead at report time with low torque and high RPM. The twenty foot core barrel is working good with one reamer shell on the bottom rather than with top and bottom shells used in the $1510^{\prime}$ to $1754^{\prime}$ interval.

Report by: Ron Jacobson 


\section{DAILY DRILLING REPORT - 08/30/93 \\ STEAMBOAT HILLS EXPLORATORY SLIMHOLE \\ Time of report -0800}

Well number - SNLG 87-29| Location - SE 1/4, SE 1/4, Section 29, T18N, R20E, Washoe County, NV

Days since spud - 41 | Depth today - 2850' | Hole advance last $24 \mathrm{hr}-130^{\prime} \mid$ Core recovered - 130' Last casing - 4-1/2", $11.5 \mathrm{lb} / \mathrm{ft} @ 524$

\begin{tabular}{|c|c|c|c|c|}
\hline \multicolumn{5}{|c|}{ BITS -- Now drilling 3.89" hole } \\
\hline Bit number & | Type $\quad 1$ & Depth in, $\mathrm{KB}$ & Depth out, KB & Footage \\
\hline 1 & 12-1/4" tri-cone & $10^{\prime}$ & $12^{\prime}$ & 2 \\
\hline 2 & HQ impreg-S2 & $12^{\prime}$ & $172^{\prime}$ & 160 \\
\hline 3 & $8-1 / 2$ " tri-cone & $12^{\prime}$ & $176^{\prime}$ & 164 \\
\hline 4 & BSF impreg-S2 & $110^{\prime}$ (cement) & $225^{\prime}$ & 115 \\
\hline 5 & BSF impreg-S8 & $225^{\prime}$ & $462^{\prime}$ & 237 \\
\hline 6 & BSF impreg-S8 & $462^{\prime}$ & $525^{\prime}$ & 63 \\
\hline 2RR & HQ impreg-S2 & $525^{\prime}$ (rock) & $673^{\prime}$ & 148 \\
\hline 7 & HQ impreg-S7 & 673 & 1149 & 476 \\
\hline 8 & HQ impreg-S8 & $1149^{\prime}$ & $1510^{+}$ & 61 \\
\hline 9 & HQ impreg-S5 & $1510^{\prime}$ & $1568^{\prime}$ & 58 \\
\hline 10 & HQ surf set & $1568^{\prime}$ & $1600^{\prime}$ & 32 \\
\hline 11 & HQ impreg-S7 & $1600^{\prime}$ & $1702^{\prime}$ & 102 \\
\hline 12 & HQ impreg-S5 & $1702^{\prime}$ & $1709^{\prime}$ & 7 \\
\hline 13 & $\mathrm{HQ}$ surf set & $1709^{\prime}$ & $1754^{\prime}$ & 45 \\
\hline 14 & HQ impreg-S5 & $1754^{\prime}$ & 1837 & 83 \\
\hline 15 & HQ impreg-S7 & 1837 & 2077 & 240 \\
\hline 16 & HQ impreg-S7 & $2077^{\prime}$ & 2077 & 0 \\
\hline 17 & HQ impreg-S7 & $2077^{\prime}$ & $2168^{\prime}$ & 91 \\
\hline 18 & HQ impreg-S8 & $2168^{\prime}$ & $2426^{\prime}$ & $258^{\circ}$ \\
\hline 19 & HQ impreg-S9 & $2426^{\prime}$ & 2437 & 11 \\
\hline 20 & HQ impreg-S7 & $2437^{\prime}$ & $2624^{\prime}$ & 187 \\
\hline 21 & HQ impreg-S7S & $2624^{\prime}$ & & \\
\hline
\end{tabular}

Drilling fluid - water, bentonite, polymer; soda ash, torkease

Flow rate $-17 \mathrm{gal} / \mathrm{min} \mid$ Pressure - 0 psi | Returns temp - n/a

$\mathrm{Wt}-8.4 \mathrm{lb} / \mathrm{gal}|\mathrm{Vis}-32 \mathrm{sec}| \mathrm{PV}-3 \mathrm{cP}\left|\mathrm{YP}-3 \mathrm{lb} / 100 \mathrm{ft}^{2}\right| \mathrm{pH}-9.0$

Lost circulation - no returns since fracture at $815^{\prime}-$

Lithology of core logged since yesterday: [Summary - detailed log available]

Core logged from 2538 ' to 261 l', no significant changes.

Summary of events last 24 hours:

Drilling ahead last 24 hours. BHT still $320 \mathrm{deg}$ F. At report time pulling 2850 core.

Report by: Ron Jacobson 


\section{DAILY DRILLING REPORT - 08/31/93 \\ STEAMBOAT HILLS EXPLORATORY SLIMHOLE \\ Time of report -0800}

Well number - SNLG 87-29 | Location - SE 1/4, SE 1/4, Section 29, T18N, R20E, Washoe County, NV

Days since spud - $42 \mid$ Depth today - 2930' Hole advance last $24 \mathrm{hr}-80^{\prime} \mid$ Core recovered - 80'

Last casing - 4-1/2", $11.5 \mathrm{lb} / \mathrm{ft}$ (a) 524'

\begin{tabular}{|c|c|c|c|c|}
\hline \multicolumn{5}{|c|}{ BITS -- Now drilling 3.89" hole } \\
\hline Bit number & | Type $\mid$ & Depth in, $\mathrm{KB}$ । & Depth out, KB & | Footage \\
\hline 1 & $12-1 / 4 "$ tri-cone & $10^{\prime}$ & $12^{\prime}$ & 2 \\
\hline 2 & HQ impreg-S2 & $12^{\prime}$ & $172^{\prime}$ & 160 \\
\hline 3 & $8-1 / 2 "$ tri-cone & $12^{\prime}$ & $176^{\prime}$ & 164 \\
\hline 4 & BSF impreg-S2 & $110^{\prime}$ (cement) & $225^{\prime}$ & 115 \\
\hline 5 & BSF impreg-S8 & $225^{\prime}$ & $462^{\prime}$ & 237 \\
\hline 6 & BSF impreg-S8 & $462^{\prime}$ & $525^{\prime}$ & 63 \\
\hline $2 \mathrm{RR}$ & HQ impreg-S2 & $525^{\prime}$ (rock) & $673^{\prime}$ & 148 \\
\hline 7 & HQ impreg-S7 & 673 & 1149 & 476 \\
\hline 8 & HQ impreg-S8 & $1149^{\prime}$ & $1510^{\prime}$ & 61 \\
\hline 9 & HQ impreg-S5 & $1510^{\prime}$ & $1568^{\prime}$ & 58 \\
\hline 10 & HQ surf set & 1568 & $1600^{\prime}$ & 32 \\
\hline 11 & HQ impreg-S7 & $1600^{\prime}$ & $1702^{\prime}$ & 102 \\
\hline 12 & HQ impreg-S5 & $1702^{\prime}$ & $1709^{\prime}$ & 7 \\
\hline 13 & HQ surf set & $1709^{\prime}$ & $1754^{\prime}$ & 45 \\
\hline 14 & HQ impreg-S5 & $1754^{\prime}$ & $1837^{\prime}$ & 83 \\
\hline 15 & HQ impreg-S7 & $1837^{\prime}$ & $2077^{\prime}$ & 240 \\
\hline 16 & HQ impreg-S7 & $2077^{\prime}$ & 2077 & 0 \\
\hline 17 & HQ impreg-S7 & 2077 & $2168^{\prime}$ & 91 \\
\hline 18 & HQ impreg-S8 & $2168^{\circ}$ & $2426^{\prime}$ & 258 \\
\hline 19 & HQ impreg-S9 & $2426^{\circ}$ & 2437 & 11 \\
\hline 20 & HQ impreg-S7 & $2437^{\prime}$ & $2624^{\prime}$ & 187 \\
\hline 21 & HQ impreg-S7S & $2624^{\prime}$ & $2930^{\prime}$ & 306 \\
\hline
\end{tabular}

Drilling fluid - water, bentonite, polymer; soda ash, torkease

Flow rate $-17 \mathrm{gal} / \mathrm{min}$ | Pressure - 0 psi | Returns temp - n/a

$\mathrm{Wt}-8.4 \mathrm{lb} / \mathrm{gal}|\mathrm{Vis}-32 \mathrm{sec}| \mathrm{PV}-3 \mathrm{cP}\left|\mathrm{YP}-3 \mathrm{lb} / 100 \mathrm{ft}^{2}\right| \mathrm{pH}-9.0$

Lost circulation - no returns since fracture at $815^{\prime}$

Lithology of core logged since yesterday: [Summary - detailed log available]

None logged

Summary of events last 24 hours:

Drilling ahead until $2300 \mathrm{~h}$ when began POOH to prepare for flow tests. RIH 280 ' with N-rod for air-lift. Started temperature $\log$ at $0300 \mathrm{~h}$. Started air compressor at $0545 \mathrm{~h}$, well began flowing on its own $(\sim 25 \mathrm{gpm})$ at $0615 \mathrm{~h}$. Killed well at $0740 \mathrm{~h}$ to $\mathrm{POOH}$ with $\mathrm{N}$-rods; will start flow test as soon as possible.

Report by: John FInger 


\section{DAILY DRILLING REPORT - 09/01/93 \\ STEAMBOAT HILLS EXPLORATORY SLIMHOLE \\ Time of report -0800}

Well number - SNLG 87-29| Location - SE 1/4, SE 1/4, Section 29, T18N, R20E, Washoe County, NV

Days since spud - $43 \mid$ Depth today - 2930' Hole advance last $24 \mathrm{hr}-0^{\prime} \mid$ Core recovered - $0^{\prime}$

Last casing-4-1/2", $11.5 \mathrm{lb} / \mathrm{ft} @ 524^{\prime}$

\begin{tabular}{|c|c|c|c|c|}
\hline \multicolumn{5}{|c|}{ BITS -- Now drilling 3.89" hole } \\
\hline Bit number & Type | & Depth in, KB | & Depth out, KB & Footage \\
\hline 1 & $12-1 / 4^{\prime \prime}$ tri-cone & $10^{\prime}$ & $12^{\prime}$ & 2 \\
\hline 2 & HQ impreg-S2 & $12^{\prime}$ & $172^{\prime}$ & 160 \\
\hline 3 & $8-1 / 2^{\prime \prime}$ tri-cone & $12^{\prime}$ & $176^{\prime}$ & 164 \\
\hline 4 & BSF impreg-S2 & $110^{\prime}$ (cement) & $225^{\prime}$ & 115 \\
\hline 5 & BSF impreg-S8 & $225^{\prime}$ & $462^{\prime}$ & 237 \\
\hline 6 & BSF impreg-S8 & $462^{\prime}$ & $525^{\prime}$ & 63 \\
\hline 2RR & HQ impreg-S2 & $525^{\prime}$ (rock) & $673^{\prime}$ & 148 \\
\hline 7 & HQ impreg-S7 & $673^{\prime}$ & 1149 & 476 \\
\hline 8 & HQ impreg-S8 & $1149^{\prime}$ & $1510^{\prime}$ & 61 \\
\hline 9 & HQ impreg-S5 & $1510^{\prime}$ & $1568^{\prime}$ & 58 \\
\hline 10 & HQ surf set & $1568^{\prime}$ & $1600^{\prime}$ & 32 \\
\hline 11 & HQ impreg-S7 & $1600^{\prime}$ & $1702^{\prime}$ & 102 \\
\hline 12 & HQ impreg-S5 & $1702^{\prime}$ & $1709^{\prime}$ & 7 \\
\hline 13 & HQ surf set & $1709^{\prime}$ & $1754^{\prime}$ & 45 \\
\hline 14 & HQ impreg-S5 & $1754^{\prime}$ & 1837 & 83 \\
\hline 15 & HQ impreg-S7 & $1837^{\prime}$ & $2077^{\prime}$ & 240 \\
\hline 16 & HQ impreg-S7 & 2077 & $2077^{\prime}$ & 0 \\
\hline 17 & HQ impreg-S7 & $2077^{\prime}$ & $2168^{\prime}$ & 91 \\
\hline 18 & HQ impreg-S8 & $2168^{\prime}$ & $2426^{\prime}$ & 258 \\
\hline 19 & HQ impreg-S9 & $2426^{\prime}$ & $2437^{\prime}$ & 11 \\
\hline 20 & HQ impreg-S7 & 2437 & $2624^{\prime}$ & 187 \\
\hline 21 & HQ impreg-S7S & $2624^{\prime}$ & $2930^{\prime}$ & 306 \\
\hline
\end{tabular}

Drilling fluid - water, bentonite, polymer; soda ash, torkease

Flow rate - $\mathbf{n} / \mathbf{a}$ gal $/ \mathrm{min} \mid$ Pressure - 0 psi | Returns temp - n/a

$\mathrm{Wt}-\mathrm{xxx} \mathrm{lb} / \mathrm{gal}|\mathrm{Vis}-\mathrm{xx} \mathrm{sec}| \mathrm{PV}-\mathrm{x} \mathrm{cP}\left|\mathrm{YP}-\mathrm{x} \mathrm{lb} / 100 \mathrm{ft}^{2}\right| \mathrm{pH}-\mathrm{xxx}$

Lost circulation - no returns since fracture at $815^{\prime}$

Lithology of core logged since yesterday: [Summary - detailed log available]

Core from $2695^{\prime}$ to $2834^{\prime}$ is the same granodiorite previously described, with numerous fractured zones and some heavily altered intervals and slickensides.

Summary of events last 24 hours:

Began flow tests with 2" James tube on outflow line, but maximum flow rate was only about $60 \mathrm{gpm}$. Took data at 60 and $45 \mathrm{gpm}$, then shut in well and changed to 3" James tube. Took data at 106, 88, 71, and $50 \mathrm{gpm}$. Shut in well for 6-1/2 hours. Rigged up to begin hot-water injection test, but logging tool was malfunctioning. Tool apparently could not be quickly repaired, and no back-up tool was on hand, so remaining tests were cancelled. Will resume drilling.

Report by: John FInger 


\section{DAILY DRILLING REPORT - 09/02/93 \\ STEAMBOAT HILLS EXPLORATORY SLIMHOLE \\ Time of report -0800}

Well number - SNLG 87-29 | Location - SE 1/4, SE 1/4, Section 29, T18N, R20E, Washoe County, NV

Days since spud - $44 \mid$ Depth today - 3050' | Hole advance last $24 \mathrm{hr}-120^{\prime} \mid$ Core recovered - $115^{\prime}$ (core lifter Last casing - 4-1/2", $11.5 \mathrm{lb} / \mathrm{ft} @ 524^{\prime}$ spring broke, but core barrel is over the stick-up)

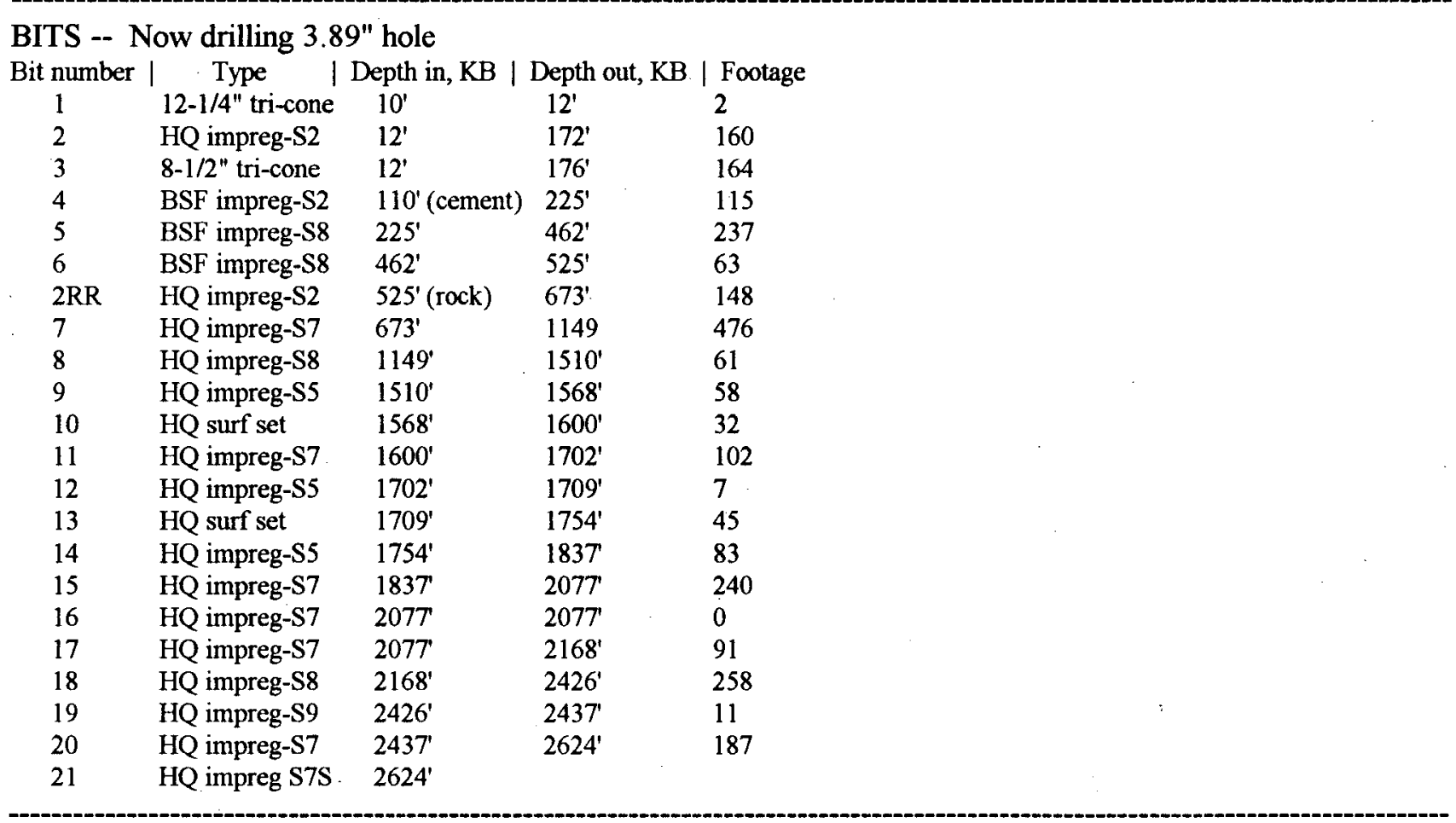

Drilling fluid - water, bentonite, polymer; soda ash, torkease

Flow rate $-18 \mathrm{gal} / \mathrm{min} \mid$ Pressure - 0 psi $\mid$ Returns temp - $\mathrm{n} / \mathrm{a}$

$\mathrm{Wt}$ - xxx lb/gal | Vis - xx sec | PV - x cP |YP - x lb/100ft ${ }^{2} \mid \mathrm{pH}-\mathrm{xxx}$

Lost circulation - no returns since fracture at $815^{\prime}$

Lithology of core logged since yesterday: [Summary - detailed log available]

Core from $2835^{\prime}$ to $2926^{\prime}$ is the same granodiorite previously described, with numerous fractured zones, slickensides, and some heavily altered intervals.

Summary of events last 24 hours:

Ran back in hole with same bit used since 2624', washed to bottom. Almost no fill at bottom of hole, indicating that most fluid movement during flow tests was in upper part of hole. Drilling is going well, with ROP averaging 8.8 $\mathrm{ft} / \mathrm{hr}$. Formation appears somewhat softer; it is also fractured, which helps the bit to strip matrix. Maximumreadiing thermometers on wireline show $325^{\circ} \mathrm{F}$, about $10^{\circ} \mathrm{F}$ higher than previous readings. Deviation survey at $3000^{\prime}$ is $1-1 / 4^{\circ}$.

Report by: John Finger 


\section{DAILY DRILLING REPORT - 09/03/93 \\ STEAMBOAT HILLS EXPLORATORY SLIMHOLE \\ Time of report -0800}

Well number - SNLG 87-29 | Location - SE 1/4, SE 1/4, Section 29, T18N, R20E, Washoe County, NV

Days since spud - 45 | Depth today - 3142' | Hole advance last $24 \mathrm{hr}-92^{\prime} \mid$ Core recovered - 97' (stick-up from Last casing - 4-1/2", $11.5 \mathrm{lb} / \mathrm{ft} @$, 524'

\begin{tabular}{|c|c|c|c|c|}
\hline \multicolumn{5}{|c|}{ BITS -- Now drilling 3.89" hole } \\
\hline Bit number & | Type | & Depth in, KB | & Depth out, KB & | Footage \\
\hline 1 & $12-1 / 4^{\prime \prime}$ tri-cone & $10^{\prime}$ & 12 & 2 \\
\hline 2 & HQ impreg-S2 & $12^{\prime}$ & $172^{\prime}$ & 160 \\
\hline 3 & $8-1 / 2 "$ tri-cone & $12^{\prime}$ & $176^{\circ}$ & 164 \\
\hline 4 & BSF impreg-S2 & $110^{\prime}$ (cement) & 225 & 115 \\
\hline 5 & BSF impreg-S8 & $225^{\prime}$ & $462^{\prime}$ & 237 \\
\hline 6 & BSF impreg-S8 & $462^{\prime}$ & $525^{\prime}$ & 63 \\
\hline $2 \mathrm{RR}$ & HQ impreg-S2 & $525^{\prime}$ (rock) & $673^{\prime}$ & 148 \\
\hline 7 & HQ impreg-S7 & $673^{\prime}$ & 1149 & 476 \\
\hline 8 & HQ impreg-S8 & $1149^{\prime}$ & $1510^{\prime}$ & 61 \\
\hline 9 & HQ impreg-S5 & $1510^{\prime}$ & $1568^{\prime}$ & 58 \\
\hline 10 & HQ surf set & $1568^{\prime}$ & $1600^{\prime}$ & 32 \\
\hline 11 & HQ impreg-S7 & $1600^{\prime}$ & $1702^{\prime}$ & 102 \\
\hline 12 & HQ impreg-S5 & $1702^{\prime}$ & $1709^{\prime}$ & 7 \\
\hline 13 & HQ surf set & $1709^{\prime}$ & $1754^{\prime}$ & 45 \\
\hline 14 & HQ impreg-S5 & $1754^{\prime}$ & $1837^{\prime}$ & 83 \\
\hline 15 & HQ impreg-S7 & 1837 & $2077^{\prime}$ & 240 \\
\hline 16 & HQ impreg-S7 & 2077 & $2077^{\prime}$ & 0 \\
\hline 17 & HQ impreg-S7 & 2077 & $2168^{\prime}$ & 91 \\
\hline 18 & HQ impreg-S8 & $2168^{\prime}$ & $2426^{\prime}$ & 258 \\
\hline 19 & HQ impreg-S9 & $2426^{\prime}$ & $2437^{\prime}$ & 11 \\
\hline 20 & HQ impreg-S7 & $2437^{\prime}$ & $2624^{\prime}$ & 187 \\
\hline 21 & HQ impreg S7S & $2624^{\prime}$ & 3072 & 448 \\
\hline 22 & HQ impreg S7S & $3072^{\prime}$ & & \\
\hline
\end{tabular}

Drilling fluid - water, bentonite, polymer; soda ash, torkease

Flow rate $-18 \mathrm{gal} / \mathrm{min} \mid$ Pressure - 0 psi | Returns temp - n/a

$\mathrm{Wt}-8.4 \mathrm{lb} / \mathrm{gal}|\mathrm{Vis}-30 \mathrm{sec}| \mathrm{PV}-2 \mathrm{cP}\left|\mathrm{YP}-3 \mathrm{lb} / 100 \mathrm{ft}^{2}\right| \mathrm{pH}-8.5$

Lost circulation - no returns since fracture at $815^{\prime}$

Lithology of core logged since yesterday: [Summary - detailed log available]

Core from $2926^{\prime}$ to $3038^{\prime}$ is the same granodiorite previously described, with only a few zones of heavy alteration and no major open fractures.

Summary of events last 24 hours:

Have drilled ahead with generally good progress. Bit change at 3072'; now using another of the same bit type that drilled $448^{\prime}$ in the previous interval.

Report by: John Finger 


\section{DAILY DRILLING REPORT - 09/04/93 \\ STEAMBOAT HILLS EXPLORATORY SLIMHOLE \\ Time of report - 0800}

Well number - SNLG 87-29 | Location - SE 1/4, SE 1/4, Section 29, T18N, R20E; Washoe County, NV

Days since spud - 46 | Depth today - 3250' | Hole advance last $24 \mathrm{hr}-108$ | Core recovered - 108

Last casing - 4-1/2", $11.5 \mathrm{lb} / \mathrm{ft}$ @ 524'

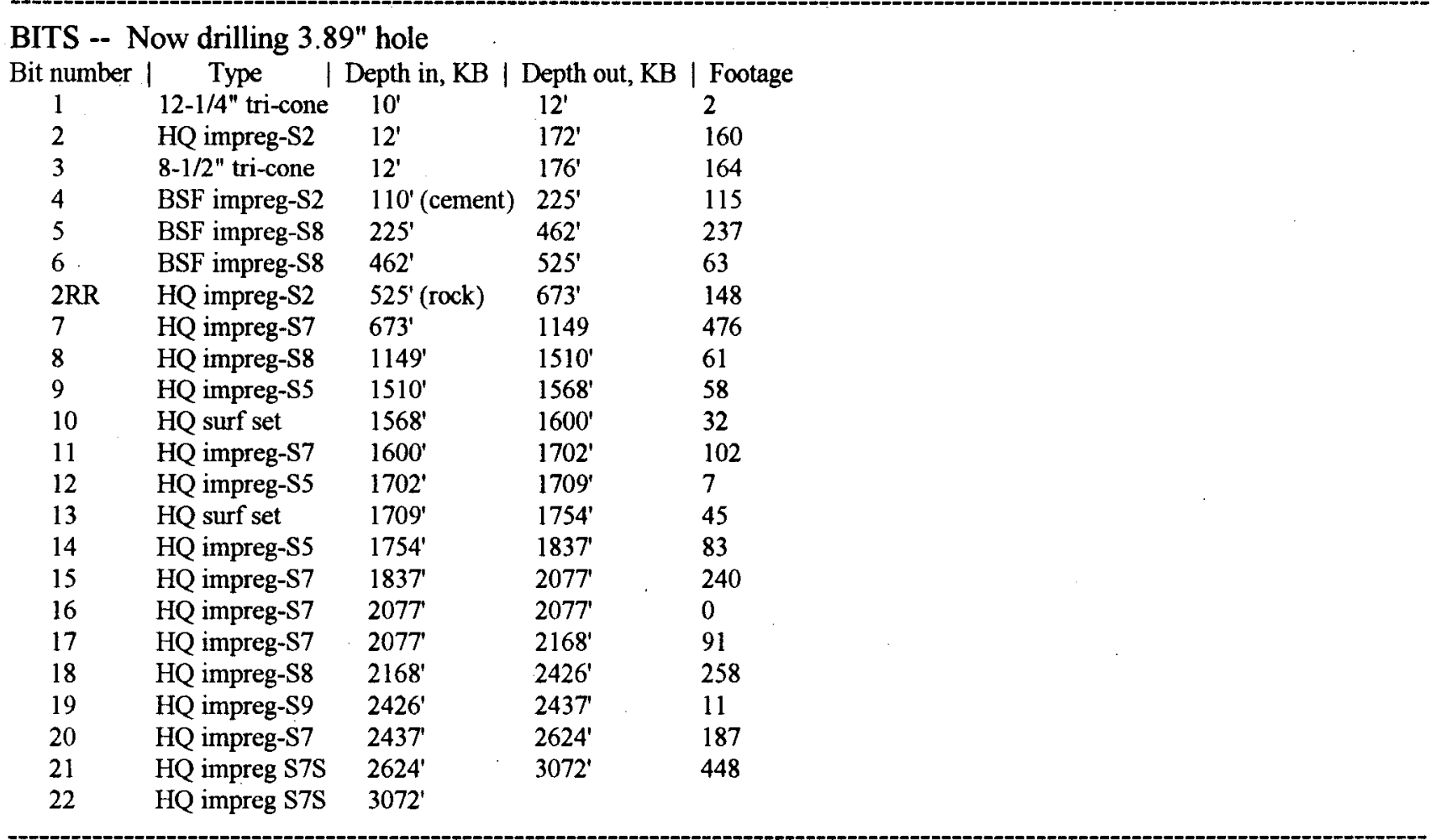

Drilling fluid - water, bentonite, polymer; soda ash, torkease

Flow rate - $18 \mathrm{gal} / \mathrm{min} \mid$ Pressure - 0 psi | Returns temp - n/a

Wt $-8.4 \mathrm{lb} / \mathrm{gal}|\mathrm{Vis}-30 \mathrm{sec}| \mathrm{PV}-2 \mathrm{cP}\left|\mathrm{YP}-3 \mathrm{lb} / 100 \mathrm{ft}^{2}\right| \mathrm{pH}-8.5$

Lost circulation - no returns since fracture at $815^{\prime}$

Lithology of core logged since yesterday: [Summary - detailed log available]

Core from $3038^{\prime}$ to $3142^{\prime}$ is the same granodiorite previously described, with a few strongly altered zones and one open $1 \mathrm{~cm}$ fracture at $3044^{\prime}$.

Summary of events last 24 hours:

Drilling ahead with reasonably good rate of penetration and no bit change.

Report by: John Finger 
DAILY DRILLING REPORT - 09/05/93

STEAMBOAT HILLS EXPLORATORY SLIMHOLE

Time of report - 0800

Well number - SNLG 87-29 | Location - SE 1/4, SE 1/4, Section 29, T18N, R20E, Washoe County, NV

Days since spud - $47 \mid$ Depth today - 3410' Hole advance last $24 \mathrm{hr}$ - 160 | Core recovered - 152 (lost 8' core, Last casing - 4-1/2", $11.5 \mathrm{lb} / \mathrm{ft} @ 524^{\prime} \quad$ probably ground up while drilling subsequent interval)

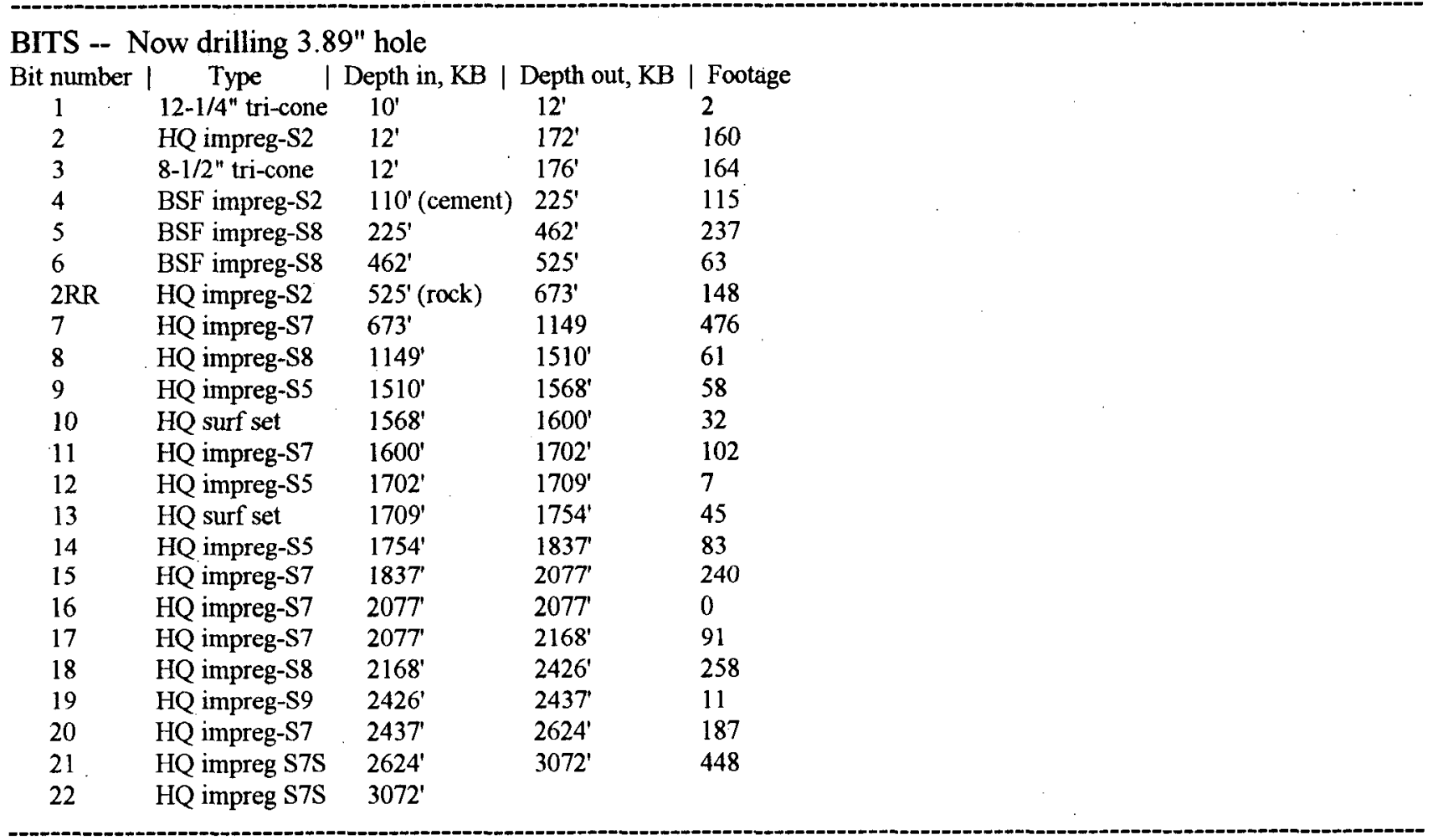

Drilling fluid - water, bentonite, polymer; soda ash, torkease

Flow rate - $18 \mathrm{gal} / \mathrm{min} \mid$ Pressure - 0 psi $\mid$ Returns temp - $\mathrm{n} / \mathrm{a}$

$\mathrm{Wt}-8.4 \mathrm{lb} / \mathrm{gal} \mid \mathrm{Vis}-32 \mathrm{sec}$ | PV.- $4 \mathrm{cP}\left|\mathrm{YP}-3 \mathrm{lb} / 100 \mathrm{ft}^{2}\right| \mathrm{pH}-8.0$

Lost circulation - no returns since fracture at $815^{\prime}$

Lithology of core logged since yesterday: [Summary - detailed log available]

No new logs today

Summary of events last 24 hours:

Drilling ahead with good rates of penetration $(\sim 10 \mathrm{ft} / \mathrm{hr})$ and no downhole vibration problems.

Report by: John Finger 


\section{DAILY DRILLING REPORT - 09/06/93 \\ STEAMBOAT HILLS EXPLORATORY SLIMHOLE \\ Time of report - 0800}

Well number - SNLG 87-29| Location - SE 1/4, SE 1/4, Section 29, T18N, R20E, Washoe County, NV

Days since spud $-48 \mid$ Depth today - 3510' Hole advance last $24 \mathrm{hr}-100 \mid$ Core recovered - 100

Last casing - 4-1/2", $11.5 \mathrm{lb} / \mathrm{ft} @ 524^{\prime}$

\begin{tabular}{|c|c|c|c|c|}
\hline \multicolumn{5}{|c|}{ BITS -- Now drilling $3.89^{\prime \prime}$ hole } \\
\hline Bit number & | Type | & Depth in, KB | & Depth out, KB & Footage \\
\hline 1 & $12-1 / 4^{\prime \prime}$ tri-cone & $10^{\prime}$ & 12 & 2 \\
\hline 2 & HQ impreg-S2 & $12^{\prime}$ & $172^{\prime}$ & 160 \\
\hline 3 & $8-1 / 2 "$ tri-cone & $12^{\prime}$ & $176^{\prime}$ & 164 \\
\hline 4 & BSF impreg-S2 & $110^{\prime}$ (cement) & $225^{\prime}$ & 115 \\
\hline 5 & BSF impreg-S8 & $225^{\prime}$ & $462^{\prime}$ & 237 \\
\hline 6 & BSF impreg-S8 & $462^{\prime}$ & $525^{\prime}$ & 63 \\
\hline 2RR & HQ impreg-S2 & $525^{\prime}$ (rock) & $673^{\prime}$ & 148 \\
\hline 7 & HQ impreg-S7 & $673^{\prime}$ & 1149 & 476 \\
\hline 8 & HQ impreg-S8 & $1149^{\prime}$ & $1510^{\prime}$ & 61 \\
\hline 9 & HQ impreg-S5 & $1510^{\prime}$ & 1568 & 58 \\
\hline 10 & HQ surf set & $1568^{\prime}$ & $1600^{\prime}$ & 32 \\
\hline 11 & HQ impreg-S7 & $1600^{\prime}$ & $1702^{\prime}$ & 102 \\
\hline 12 & HQ impreg-S5 & $1702^{\prime}$ & $1709^{\prime}$ & 7 \\
\hline 13 & HQ surf set & $1709^{\prime}$ & $1754^{\prime}$ & 45 \\
\hline 14 & HQ impreg-S5 & $1754^{\prime}$ & 1837 & 83 \\
\hline 15 & HQ impreg-S7 & $1837^{\prime}$ & $2077^{\prime}$ & 240 \\
\hline 16 & HQ impreg-S7 & 2077 & $2077^{\prime}$ & 0 \\
\hline 17 & HQ impreg-S7 & $2077^{\prime}$ & $2168^{\prime}$ & 91 \\
\hline 18 & HQ impreg-S8 & $2168^{\prime}$ & $2426^{\prime}$ & 258 \\
\hline 19 & HQ impreg-S9 & $2426^{\prime}$ & $2437^{\prime}$ & 11 \\
\hline 20 & HQ impreg-S7 & 2437 & $2624^{\prime}$ & 187 \\
\hline 21 & HQ impreg S7S & $2624^{\prime}$ & $3072^{\prime}$ & 448 \\
\hline 22 & HQ impreg S7S & $3072^{\prime}$ & $3450^{\prime}$ & 378 \\
\hline
\end{tabular}

Drilling fluid - water, bentonite, polymer; soda ash, torkease

Flow rate $-18 \mathrm{gal} / \mathrm{min}$ | Pressure - 0 psi | Returns temp - $\mathrm{n} / \mathrm{a}$

$\mathrm{Wt}-8.4 \mathrm{lb} / \mathrm{gal}|\mathrm{Vis}-32 \mathrm{sec}| \mathrm{PV}-4 \mathrm{cP}\left|\mathrm{YP}-3 \mathrm{lb} / 100 \mathrm{ft}^{2}\right| \mathrm{pH}-8.0$

Lost circulation - no returns since fracture at $815^{\prime}$

Lithology of core logged since yesterday: [Summary - detailed log available]

No new logs today

Summary of events last 24 hours:

Drilled ahead with good rate of penetration $(\sim 10 \mathrm{ft} / \mathrm{hr})$ to $3450^{\prime}$. POOH for bit change. Rigged up SNL logging truck for temperature log. RIH with temperature tool to $\sim 2600^{\prime}$ when frayed outer braid on wireline packed a rat'snest into the cable guide. Cleared tangled wire, $\mathrm{POOH}$ with logging tool, but wireline is suspect for logging to bottom of hole. Current plan is to bring logging truck from Mammoth Lakes and do temperature log when corehole reaches 4000'; at that point Far West can decide whether to assume the expense of continuing the hole..

Report by: John Finger 


\section{DAILY DRILLING REPORT - 09/07/93 \\ STEAMBOAT HILLS EXPLORATORY SLIMHOLE \\ Time of report -0800}

Well number - SNLG 87-29 | Location - SE 1/4, SE 1/4, Section 29, T18N, R20E, Washoe County, NV

Days since spud - 49 | Depth today - 3640' $\mid$ Hole advance last $24 \mathrm{hr}-130^{\prime} \mid$ Core recovered - 130'

Last casing - 4-1/2", $11.5 \mathrm{lb} / \mathrm{ft} @ 524^{\prime}$

BITS -- Now drilling 3.89" hole

\begin{tabular}{clllll} 
Bit number & \multicolumn{2}{c}{ Type } & Depth in, KB | & \multicolumn{2}{c}{ Depth out, KB | Footage } \\
1 & 12-1/4" tri-cone & $10^{\prime}$ & $12^{\prime}$ & 2 \\
2 & HQ impreg-S2 & $12^{\prime}$ & $172^{\prime}$ & 160 \\
3 & $8-1 / 2^{\prime \prime}$ tri-cone & $12^{\prime}$ & $176^{\prime}$ & 164 \\
4 & BSF impreg-S2 & $110^{\prime}$ (cement) & $225^{\prime}$ & 115 \\
5 & BSF impreg-S8 & $225^{\prime}$ & $462^{\prime}$ & 237 \\
6 & BSF impreg-S8 & $462^{\prime}$ & $525^{\prime}$ & 63 \\
2 RR & HQ impreg-S2 & $525^{\prime}$ (rock) & $673^{\prime}$ & 148 \\
7 & HQ impreg-S7 & $673^{\prime}$ & 1149 & 476 \\
8 & HQ impreg-S8 & $1149^{\prime}$ & $1510^{\prime}$ & 61 \\
9 & HQ impreg-S5 & $1510^{\prime}$ & $1568^{\prime}$ & 58 \\
10 & HQ surf set & $1568^{\prime}$ & $1600^{\prime}$ & 32 \\
11 & HQ impreg-S7 & $1600^{\prime}$ & $1702^{\prime}$ & 102 \\
12 & HQ impreg-S5 & $1702^{\prime}$ & $1709^{\prime}$ & 7 \\
13 & HQ surf set & $1709^{\prime}$ & $1754^{\prime}$ & 45 \\
14 & HQ impreg-S5 & $1754^{\prime}$ & $1837^{\prime}$ & 83 \\
15 & HQ impreg-S7 & $1837^{\prime}$ & $2077^{\prime}$ & 240 \\
16 & HQ impreg-S7 & $2077^{\prime}$ & $2077^{\prime}$ & 0 \\
17 & HQ impreg-S7 & $2077^{\prime}$ & $2168^{\prime}$ & 91 \\
18 & HQ impreg-S8 & $2168^{\prime}$ & $2426^{\prime}$ & 258 \\
19 & HQ impreg-S9 & $2426^{\prime}$ & $2437^{\prime}$ & 11 \\
20 & HQ impreg-S7 & $2437^{\prime}$ & $2624^{\prime}$ & 187 \\
21 & HQ impreg S7S & $2624^{\prime}$ & $3072^{\prime}$ & 448 \\
22 & HQ impreg S7S & $3072^{\prime}$ & $3450^{\prime}$ & 378 \\
23 & HQ impreg & $3450^{\prime}$ & &
\end{tabular}

Drilling fluid - water, bentonite, polymer; soda ash, torkease

Flow rate $-18 \mathrm{gal} / \mathrm{min}$ | Pressure - 0 psi | Returns temp - n/a

$\mathrm{Wt}-8.4 \mathrm{lb} / \mathrm{gal}|\mathrm{Vis}-32 \mathrm{sec}| \mathrm{PV}-4 \mathrm{cP}\left|\mathrm{YP}-4 \mathrm{lb} / 100 \mathrm{ft}^{2}\right| \mathrm{pH}-8.0$

Lost circulation - no returns since fracture at $815^{\prime}$

Lithology of core logged since yesterday: [Summary - detailed log available]

No new logs today

Summary of events last 24 hours:

Have drilled ahead with good rate of penetration $(\sim 10 \mathrm{ft} / \mathrm{hr})$ since $3510^{\prime}$. Some downhole torque, pulling out of hole to grease rods and inspect bit.

Report by: John Finger 


\section{DAILY DRILLING REPORT - 09/08/93 \\ STEAMBOAT HILLS EXPLORATORY SLIMHOLE \\ Time of report -.0800}

Well number - SNLG 87-29 | Location - SE 1/4, SE 1/4, Section 29, T18N, R20E, Washoe County, NV

Days since spud - 50| Depth today - 3730' $\mid$ Hole advance last $24 \mathrm{hr}-90^{\prime} \mid$ Core recovered - 90'

Last casing - 4-1/2", $11.5 \mathrm{lb} / \mathrm{ft} @ 524^{\prime}$

\begin{tabular}{|c|c|c|c|c|}
\hline \multicolumn{5}{|c|}{ BITS -- Now drilling 3.89" hole } \\
\hline Bit number & | Type $\quad$ | & Depth in, $\mathrm{KB}$ & Depth out, KB & | Footage \\
\hline 1 & $12-1 / 4 "$ tri-cone & $10^{\prime}$ & $12^{\prime}$ & 2 \\
\hline 2 & HQ impreg-S2 & $12^{\prime}$ & $172^{\prime}$ & 160 \\
\hline 3 & $8-1 / 2^{\prime \prime}$ tri-cone & $12^{\prime}$ & $176^{\prime}$ & 164 \\
\hline 4 & BSF impreg-S2 & $110^{\prime}$ (cement) & $225^{\prime}$ & 115 \\
\hline 5 & BSF impreg-S8 & $225^{\prime}$ & $462^{\prime}$ & 237 \\
\hline 6 & BSF impreg-S8 & $462^{\prime}$ & $525^{\prime}$ & 63 \\
\hline 2RR & HQ impreg-S2 & $525^{\prime}$ (rock) & 673' & 148 \\
\hline 7 & HQ impreg-S7 & $673^{\prime}$ & 1149 & 476 \\
\hline 8 & HQ impreg-S8 & $1149^{\prime}$ & $1510^{\prime}$ & 61 \\
\hline 9 & HQ impreg-S5 & $1510^{\prime}$ & $1568^{\prime}$ & 58 \\
\hline 10 & HQ surf set & $1568^{\prime}$ & $1600^{\prime}$ & 32 \\
\hline 11 & HQ impreg-S7 & $1600^{\prime}$ & $1702^{\prime}$ & 102 \\
\hline 12 & HQ impreg-S5 & $1702^{\prime}$ & $1709^{\prime}$ & 7 \\
\hline 13 & HQ surf set & $1709^{\prime}$ & $1754^{\prime}$ & 45 \\
\hline 14 & HQ impreg-S5 & $1754^{\prime}$ & 1837 & 83 \\
\hline 15 & HQ impreg-S7 & 1837 & 2077 & 240 \\
\hline 16 & HQ impreg-S7 & $2077^{\prime}$ & 2077 & 0 \\
\hline 17 & HQ impreg-S7 & $2077^{\prime}$ & $2168^{\prime}$ & 91 \\
\hline 18 & HQ impreg-S8 & $2168^{\prime}$ & $2426^{\prime}$ & 258 \\
\hline 19 & HQ impreg-S9 & $2426^{\prime}$ & 2437 & 11 \\
\hline 20 & HQ impreg-S7 & 2437 & $2624^{\prime}$ & 187 \\
\hline 21 & HQ impreg S7S & $2624^{\prime}$ & $3072^{\prime}$ & 448 \\
\hline 22 & HQ impreg S7S & $3072^{\prime}$ & $3450^{\prime}$ & 378 \\
\hline 23 & HQ impreg S7S & $3450^{\prime}$ & $3650^{\prime \prime}$ & 200 \\
\hline 24 & HQ impreg S7S & $3650^{\prime}$ & & \\
\hline
\end{tabular}

Drilling fluid - water, bentonite, polymer; soda ash, torkease

Flow rate $-18 \mathrm{gal} / \mathrm{min}$ | Pressure - 0 psi | Returns temp - n/a

Wt $-8.4 \mathrm{lb} / \mathrm{gal}|\mathrm{Vis}-32 \mathrm{sec}| \mathrm{PV}-4 \mathrm{cP}\left|\mathrm{YP}-4 \mathrm{lb} / 100 \mathrm{ft}^{2}\right| \mathrm{pH}-8.0$

Lost circulation - no returns since fracture at $815^{\prime}$

Lithology of core logged since yesterday: [Summary - detailed log available]

Logs received from 3142 to $3264^{\prime}$. Mostly the same granodiorite previously described with a extremely vuggy zone at $3210^{\prime}$.

Summary of events last 24 hours:

Drilling ahead at report time. POOH at $3650 \mathrm{ft}$ to grease rods, bit about $40 \%$ wore but changed out anyway. Will rerun if needed to get to planned TD. Set down with new bit at $268^{\prime}$ and could not work thru. POOH and checked bit, it is slightly over gage, 3.925". PU new bit and RIH. Had to wrench through tight spot at 268'. 15 hours drilling time, 7 hours tripping and 2 hours rig repair.

Report by: Ron Jacobson 


\section{DAILY DRILLING REPORT - 09/09/93 \\ STEAMBOAT HILLS EXPLORATORY SLIMHOLE \\ Time of report -0800}

Well number - SNLG 87-29 | Location - SE 1/4, SE 1/4, Section 29, T18N, R20E, Washoe County, NV

Days since spud - $51 \mid$ Depth today - 3810' | Hole advance last $24 \mathrm{hr}-80^{\prime} \mid$ Core recovered - 78'

Last casing - 4-1/2", $11.5 \mathrm{lb} / \mathrm{ft} @ 524^{\prime}$

\begin{tabular}{|c|c|c|c|c|}
\hline \multicolumn{5}{|c|}{ BITS -- Now drilling 3.89" hole } \\
\hline Bit number & 1 Type $\quad$ | & Depth in, KB । & Depth out, KB & | Footage \\
\hline 1 & 12-1/4" tri-cone & $10^{\prime}$ & $12^{\prime}$ & 2 \\
\hline 2 & HQ impreg-S2 & $12^{\prime}$ & $172^{\prime}$ & 160 \\
\hline 3 & 8-1/2" tri-cone & $12^{\prime}$ & $176^{\prime}$ & 164 \\
\hline 4 & BSF impreg-S2 & $110^{\prime}$ (cement) & $225^{\prime}$ & 115 \\
\hline 5 & BSF impreg-S8 & $225^{\prime}$ & $462^{\prime}$ & 237 \\
\hline 6 & BSF impreg-S8 & $462^{\prime}$ & $525^{\prime}$ & 63 \\
\hline 2RR & HQ impreg-S2 & $525^{\prime}$ (rock) & $673^{\prime}$ & 148 \\
\hline 7 & HQ impreg-S7 & $673^{\prime}$ & 1149 & 476 \\
\hline 8 & HQ impreg-S8 & $1149^{\prime}$ & $1510^{\prime}$ & 61 \\
\hline 9 & HQ impreg-S5 & $1510^{\prime}$ & $1568^{\prime}$ & 58 \\
\hline 10 & HQ surf set & $1568^{\prime}$ & $1600^{\prime}$ & 32 \\
\hline 11 & HQ impreg-S7 & $1600^{\prime}$ & $1702^{\prime}$ & 102 \\
\hline 12 & HQ impreg-S5 & $1702^{\prime}$ & $1709^{\prime}$ & 7 \\
\hline 13 & HQ surf set & $1709^{\prime}$ & $1754^{\prime}$ & 45 \\
\hline 14 & HQ impreg-S5 & $1754^{\prime}$ & 1837 & 83 \\
\hline 15 & HQ impreg-S7 & 1837 & 2077 & 240 \\
\hline 16 & HQ impreg-S7 & $2077^{\prime}$ & $2077^{\prime}$ & 0 \\
\hline 17 & HQ impreg-S7 & 2077 & $2168^{\prime}$ & 91 \\
\hline 18 & HQ impreg-S8 & $2168^{\prime}$ & $2426^{\prime}$ & 258 \\
\hline 19 & HQ impreg-S9 & $2426^{\prime}$ & $2437^{\prime}$ & 11 \\
\hline 20 & HQ impreg-S7 & 2437 & $2624^{\prime}$ & 187 \\
\hline 21 & HQ impreg S7S & $2624^{\prime}$ & $3072^{\prime}$ & 448 \\
\hline 22 & HQ impreg S7S & $3072^{\prime}$ & $3450^{\prime}$ & 378 \\
\hline 23 & HQ impreg S7S & $3450^{\prime}$ & $3650^{\prime}$ & 200 \\
\hline 24 & HQ impreg S7S & $3650^{\prime}$ & $3810^{\prime}$ & $160^{\circ}$ \\
\hline 25 & HQ impreg $\mathrm{S} 10$ & $3810^{\prime}$ & & \\
\hline
\end{tabular}

Drilling fluid - water, bentonite, polymer; soda ash, torkease

Flow rate $-18 \mathrm{gal} / \mathrm{min} \mid$ Pressure - 0 psi | Returns temp - n/a

$\mathrm{Wt}-8.4 \mathrm{lb} / \mathrm{gal}|\mathrm{Vis}-32 \mathrm{sec}| \mathrm{PV}-4 \mathrm{cP}\left|\mathrm{YP}-4 \mathrm{lb} / 100 \mathrm{ft}^{2}\right| \mathrm{pH}-8.0$

Lost circulation - no returns since fracture at $815^{\prime}$

Lithology of core logged since yesterday: [Summary - detailed log available]

No new logs today.

Summary of events last 24 hours:

Drilling indicates that formation has gotten harder. Rate of penetration and bit life are down. POOH at $3810^{\prime}$ for bit change; ran temperature log. Bottom-hole temperature is less than $300^{\circ} \mathrm{F}$. Running back in hole with new bit at report time.

Report by: John Finger 


\section{DAILY DRILLING REPORT - 09/10/93 \\ STEAMBOAT HILLS EXPLORATORY SLIMHOLE}

Time of report -0800

Well number - SNLG 87-29 | Location - SE 1/4, SE 1/4, Section 29, T18N, R20E, Washoe County, NV

Days since spud - $52 \mid$ Depth today - 3960' $\mid$ Hole advance last $24 \mathrm{hr}-150^{\prime} \mid$ Core recovered - 150' Last casing - 4-1/2", $11.5 \mathrm{lb} / \mathrm{ft} @$ (524'

\begin{tabular}{|c|c|c|c|c|}
\hline \multicolumn{5}{|c|}{ BITS -- Now drilling 3.89" hole } \\
\hline Bit number & | Type | & Depth in, $\mathrm{KB}$ । & Depth out, KB & Footage \\
\hline 1 & $12-1 / 4^{\prime \prime}$ tri-cone & $10^{\prime}$ & $12^{\prime}$ & 2 \\
\hline 2 & HQ impreg-S2 & $12^{\prime}$ & $172^{\prime}$ & 160 \\
\hline 3 & $8-1 / 2^{\prime \prime}$ tri-cone & $.12^{\prime}$ & $176^{\prime}$ & 164 \\
\hline 4 & BSF impreg-S2 & $110^{\prime}$ (cement) & $225^{\prime}$ & 115 \\
\hline 5 & BSF impreg-S8 & 225 & $462^{\prime}$ & 237 \\
\hline 6 & BSF impreg-S8 & $462^{\prime}$ & $525^{\prime}$ & 63 \\
\hline $2 \mathrm{RR}$ & HQ impreg-S2 & $525^{\prime}$ (rock) & $673^{\prime}$ & 148 \\
\hline 7 & $\mathrm{HQ}$ impreg-S7 & $673^{\prime}$ & 1149 & 476 \\
\hline 8 & HQ impreg-S8 & $1149^{\prime}$ & $1510^{\prime}$ & 61 \\
\hline 9 & HQ impreg-S5 & $1510^{\prime}$ & $1568^{\prime}$ & 58 \\
\hline 10 & HQ surf set & $1568^{\prime}$ & $1600^{\prime}$ & 32 \\
\hline 11 & HQ impreg-S7 & $1600^{\prime}$ & $1702^{\prime}$ & 102 \\
\hline 12 & $\mathrm{HQ}$ impreg-S5 & $1702^{\prime}$ & $1709^{\prime}$ & 7 \\
\hline 13 & HQ surf set & $1709^{\prime}$ & $1754^{\prime}$ & 45 \\
\hline 14 & HQ impreg-S5 & $1754^{\prime}$ & $1837^{\prime}$ & 83 \\
\hline 15 & HQ impreg-S7 & $1837^{\prime}$ & 2077 & 240 \\
\hline 16 & HQ impreg-S7 & $2077^{\prime}$ & $2077^{\prime}$ & 0 \\
\hline 17 & HQ impreg-S7 & $2077^{\prime}$ & $2168^{\prime}$ & 91 \\
\hline 18 & HQ impreg-S8 & $2168^{\prime}$ & $2426^{\prime}$ & 258 \\
\hline 19 & HQ impreg-S9 & $2426^{\prime}$ & $2437^{\prime}$ & 11 \\
\hline 20 & HQ impreg-S7 & 2437 & $2624^{\prime}$ & 187 \\
\hline 21 & HQ impreg S7S & $2624^{\prime}$ & $3072^{\prime}$ & 448 \\
\hline 22 & HQ impreg S7S & $3072^{\prime}$ & $3450^{\prime}$ & 378 \\
\hline 23 & HQ impreg S7S & $3450^{\prime}$ & $3650^{\prime}$ & 200 \\
\hline 24 & HQ impreg S7S & $3650^{\prime}$ & $3810^{\prime}$ & 160 \\
\hline 25 & HQ impreg $\mathrm{S} 10$ & $3810^{\prime}$ & & \\
\hline
\end{tabular}

Drilling fluid - water, bentonite, polymer; soda ash, torkease

Flow rate $-18 \mathrm{gal} / \mathrm{min} \mid$ Pressure - -0 psi | Returns temp - $\mathrm{n} / \mathrm{a}$

$\mathrm{Wt}-8.4 \mathrm{lb} / \mathrm{gal}|\mathrm{Vis}-32 \mathrm{sec}| \mathrm{PV}-4 \mathrm{cP}\left|\mathrm{YP}-3 \mathrm{lb} / 100 \mathrm{ft}^{2}\right| \mathrm{pH}-8.0$

Lost circulation - no returns since fracture at $815^{\prime}$.

Lithology of core logged since yesterday: [Summary - detailed log available]

No new logs today

Summary of events last 24 hours:

Have been drilling ahead since 1030 yesterday. Rate of penetration is good $(8-9 \mathrm{ft} / \mathrm{hr})$, minor torque. We are near the target of 4000', but there is still a question of whether to continue drilling. A major fracture zone near 3600' shows mineralization that does not usually occur below a temperature of $350^{\circ} \mathrm{F}$, but temperature $\log$ to $3800^{\prime}$ shows less than $300^{\circ} \mathrm{F}$ at that depth. After drilling either to $4000^{\prime}$ or until the current bit is gone, we will attempt to resolve this by making additional temperature measurements while restricting the possible flow of cold water from above $3600^{\prime}$. 


\section{DAILY DRILLING REPORT - 09/13/93 \\ STEAMBOAT HILLS EXPLORATORY SLIMHOLE \\ Time of report -0800}

Well number - SNLG 87-29 | Location - SE 1/4, SE 1/4, Section 29, T18N, R20E, Washoe County, NV

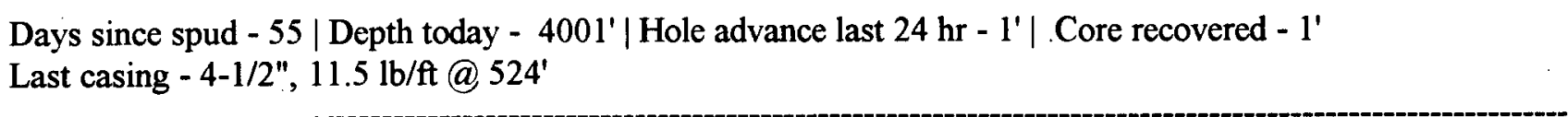

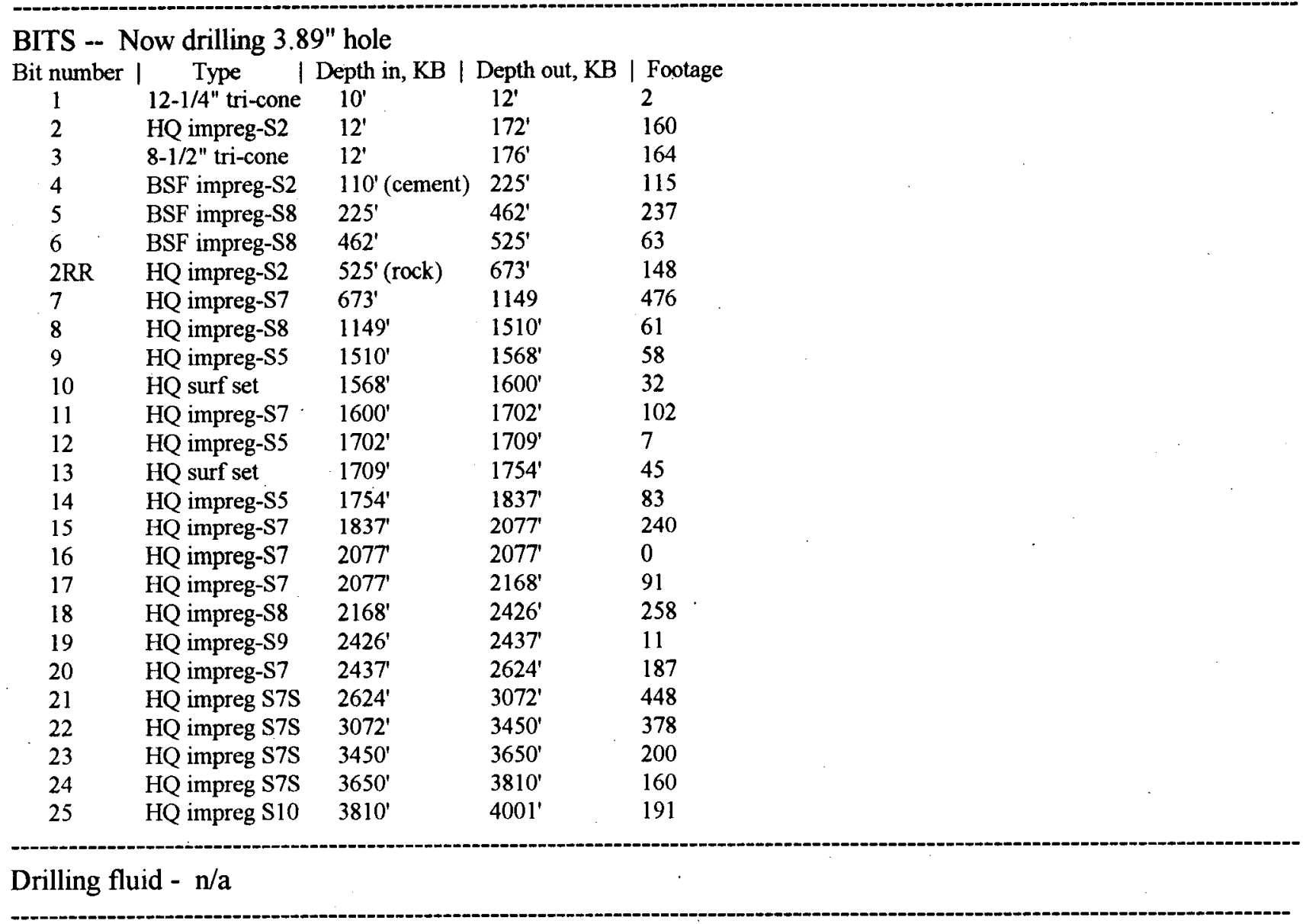

Lithology of core logged since yesterday: [Summary - detailed log available] No new logs today

Summary of events last 24 hours:

Ran logging company's PTS tool into flowing hole; got downhole data to 2700', then their tool sat down on the same obstruction that stopped SNL log on Saturday. This confirms that there is an actual bridge of some sort, not just a flow phenomenon that tangled the SNL wireline. Pulled PTS tool back to $805^{\prime}$ (just above production zone) and shut well in for 5 hours. POOH with logging tool, RIH with drill pipe to 2800 ', felt no obstruction, but examination of core shows fractured zone where tool stopped. RIH with SNL temperature tool and pressure/temperature memory tool. Could not get past $3208^{\prime}$ (core shows very large fracture there) and $\mathrm{POOH}$. Memory tool has no data; temperature tool shows that upper part of hole has heated relative to the static log on Friday (as expected after 20+ hours of flow), but that the lower part has cooled. Run in hole with rest of drill pipe and core 1 ' to capture any cave that has fallen in the hole. POOH with drill pipe; at report time rigging for another attempt at SNL temperature log to bottom.

Report by: John Finger 


\section{DAILY DRILLING REPORT - 09/11/93 \\ STEAMBOAT HILLS EXPLORATORY SLIMHOLE}

Time of report -0800

Well number - SNLG 87-29 | Location - SE 1/4, SE 1/4, Section 29, T18N, R20E, Washoe County, NV

Days since spud - 53 | Depth today - 4000' Hole advance last $24 \mathrm{hr}-40^{\prime} \mid$ Core recovered - 40'

Last casing - 4-1/2", $11.5 \mathrm{lb} / \mathrm{ft} @ 524^{\prime}$

\begin{tabular}{|c|c|c|c|c|}
\hline \multicolumn{5}{|c|}{ BITS -- Now drilling $3.89^{\prime \prime}$ hole } \\
\hline Bit number & I Type $\quad \mid$ & Depth in, $\mathrm{KB}$ । & Depth out, KB & | Footage \\
\hline 1 & $12-1 / 4^{\prime \prime}$ tri-cone & $10^{\prime}$ & $12^{\prime}$ & 2 \\
\hline 2 & HQ impreg-S2 & $12^{\prime}$ & $172^{\prime}$ & 160 \\
\hline 3 & $8-1 / 2 "$ tri-cone & $12^{\prime}$ & $176^{\prime}$ & 164 \\
\hline 4 & BSF impreg-S2 & $110^{\prime}$ (cement) & $225^{\prime}$ & 115 \\
\hline 5 & BSF impreg-S8 & $225^{\prime}$ & $462^{\prime}$ & 237 \\
\hline 6 & BSF impreg-S8 & $462^{\prime}$ & $525^{\prime}$ & 63 \\
\hline 2RR & HQ impreg-S2 & $525^{\prime}$ (rock) & $673^{\prime}$ & 148 \\
\hline 7 & HQ impreg-S7 & $673^{\prime}$ & 1149 & 476 \\
\hline 8 & HQ impreg-S8 & $1149^{\prime}$ & $1510^{\prime}$ & 61 \\
\hline 9 & HQ impreg-S5 & $1510^{\prime}$ & $1568^{\prime}$ & 58 \\
\hline 10 & HQ surf set & $1568^{\circ}$ & $1600^{\prime}$ & 32 \\
\hline 11 & HQ impreg-S7 & $1600^{\prime}$ & $1702^{\prime}$ & 102 \\
\hline 12 & HQ impreg-S5 & $1702^{\prime}$ & $1709^{\prime}$ & 7 \\
\hline 13 & HQ surf set & $1709^{\prime}$ & $1754^{\prime}$ & 45 \\
\hline 14 & HQ impreg-S5 & $1754^{\prime}$ & $1837^{\prime}$ & 83 \\
\hline 15 & HQ impreg-S7 & $1837^{\prime}$ & $2077^{\prime}$ & 240 \\
\hline 16 & HQ impreg-S7 & 2077 & 2077 & 0 \\
\hline 17 & HQ impreg-S7 & $2077^{\prime}$ & $2168^{\prime}$ & 91 \\
\hline 18 & HQ impreg-S8 & 2168 & $2426^{\prime}$ & 258 \\
\hline 19 & HQ impreg-S9 & $2426^{\prime}$ & 2437 & 11 \\
\hline 20 & HQ impreg-S7 & $2437^{\prime}$ & $2624^{\prime}$ & 187 \\
\hline 21 & HQ impreg S7S & $2624^{\prime}$ & $3072^{\prime}$ & 448 \\
\hline 22 & HQ impreg S7S & $3072^{\prime}$ & $3450^{\prime}$ & 378 \\
\hline 23 & HQ impreg S7S & $3450^{\prime}$ & $3650^{\prime}$ & 200 \\
\hline 24 & HQ impreg S7S & $3650^{\prime}$ & $3810^{\prime}$ & 160 \\
\hline 25 & HQ impreg S10 & $3810^{\prime}$ & $4000^{\prime}$ & 190 \\
\hline
\end{tabular}

Drilling fluid - water, bentonite, polymer; soda ash, torkease

Flow rate $-18 \mathrm{gal} / \mathrm{min} \mid$ Pressure - $0 \mathrm{psi} \mid$ Returns temp - $\mathrm{n} / \mathrm{a}$

Wt $-8.4 \mathrm{lb} / \mathrm{gal}|\mathrm{Vis}-32 \mathrm{sec}| \mathrm{PV}-4 \mathrm{cP}\left|\mathrm{YP}-3 \mathrm{lb} / 100 \mathrm{ft}^{2}\right| \mathrm{pH}-8.0$

Lost circulation - no returns since fracture at $815^{\prime}$

Lithology of core logged since yesterday: [Summary - detailed log available]

No new logs today

Summary of events last 24 hours:

Reached $4000^{\prime}$ at 1200 yesterday. Pulled out of hole to $3500^{\prime}$, with the idea that the bit will restrict intra-wellbore flow. Ran temperature log to $4000^{\prime}$ and left tool hanging at $3990^{\prime}$ for 12 hours. Bottom-hole temperature decreased by approximately $1.5^{\circ} \mathrm{C}$. Logged back up; hole temperatures were slightly higher in some parts of the hole and lower in others. Pulling out of hole in preparation for flow test.

Report by: John Finger 


\section{DAILY DRILLING REPORT - 09/12/93 \\ STEAMBOAT HILLS EXPLORATORY SLIMHOLE \\ Time of report - 0800}

Well number - SNLG 87-29 | Location - SE 1/4, SE 1/4, Section 29, T18N, R20E, Washoe County, NV

Days since spud - $54 \mid$ Depth today - 4000' $\mid$ Hole advance last $24 \mathrm{hr}-0^{\prime} \mid$ Core recovered - $0^{\prime}$

Last casing - 4-1/2", $11.5 \mathrm{lb} / \mathrm{ft} @ 524^{\prime}$

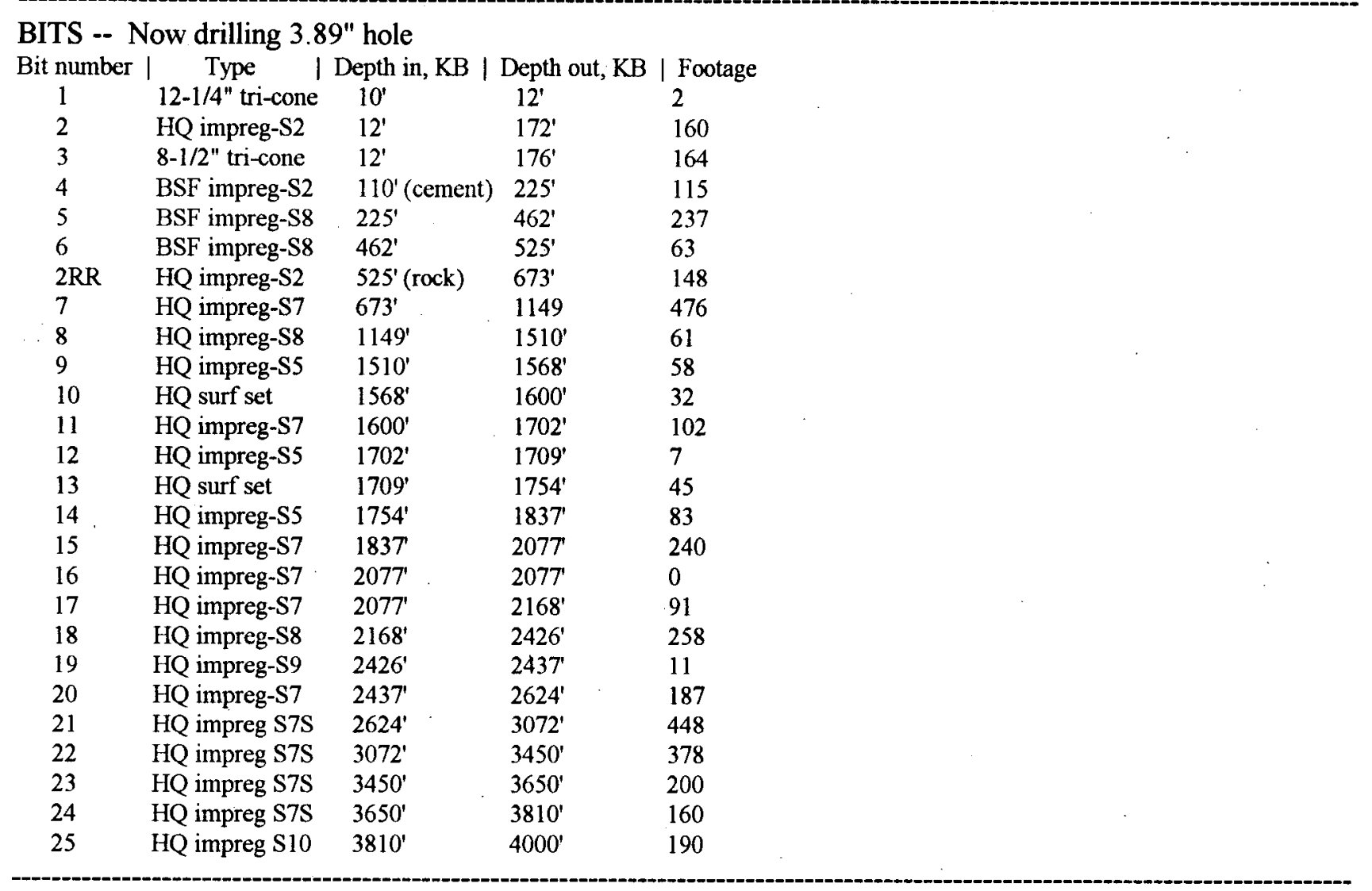

Drilling fluid - $\mathrm{n} / \mathrm{a}$

Lithology of core logged since yesterday: [Summary - detailed log available] No new logs today

Summary of events last 24 hours:

Completed pulling out of hole with drill pipe. Pressurized wellhead, held for an hour, and released. Flow began. Ran in hole to $2700^{\prime}$ with SNL temperature tool and tool sat down on an obstruction in the wellbore; wireline became tangled, and could not lower tool. Pulled out of hole to $1700^{\prime}$ and wireline tangle stuck in lubricator. Killed well, let lubricator cool, and pulled out bad line (severely frayed at knot area.) Pulled temperature tool to surface, laid it down, spooled out wireline to bad spot, and cut it off. Will rehead wireline, giving enough lengrh to reach bottom of hole. SNL pressure-temperature memory tool is not currently working because of a problem with the temperature transducer. Waited on logging company until 0530; at report time the depth counter on their truck is not working. Well has been flowing for approximately 20 hours; we have good surface data (flow rate, wellhead pressure and temperature, lip pressure) for that interval, but no useful downhole logs other than the flowing temperature $\log$ to $2700^{\prime}$.

Report by: John Finger 
DAILY DRILLING REPORT - 09/14/93

STEAMBOAT HILLS EXPLORATORY SLIMHOLE

Time of report - 0800

Well number - SNLG 87-29 | Location - SE 1/4, SE 1/4, Section 29, T18N, R20E, Washoe County, NV

Days since spud - 56 | Depth today - 4001' $\mid$ Hole advance last $24 \mathrm{hr}-0^{\prime} \mid$ Core recovered - $0^{\prime}$

Last casing - 4-1/2", $11.5 \mathrm{lb} / \mathrm{ft} @ 524^{\prime}$

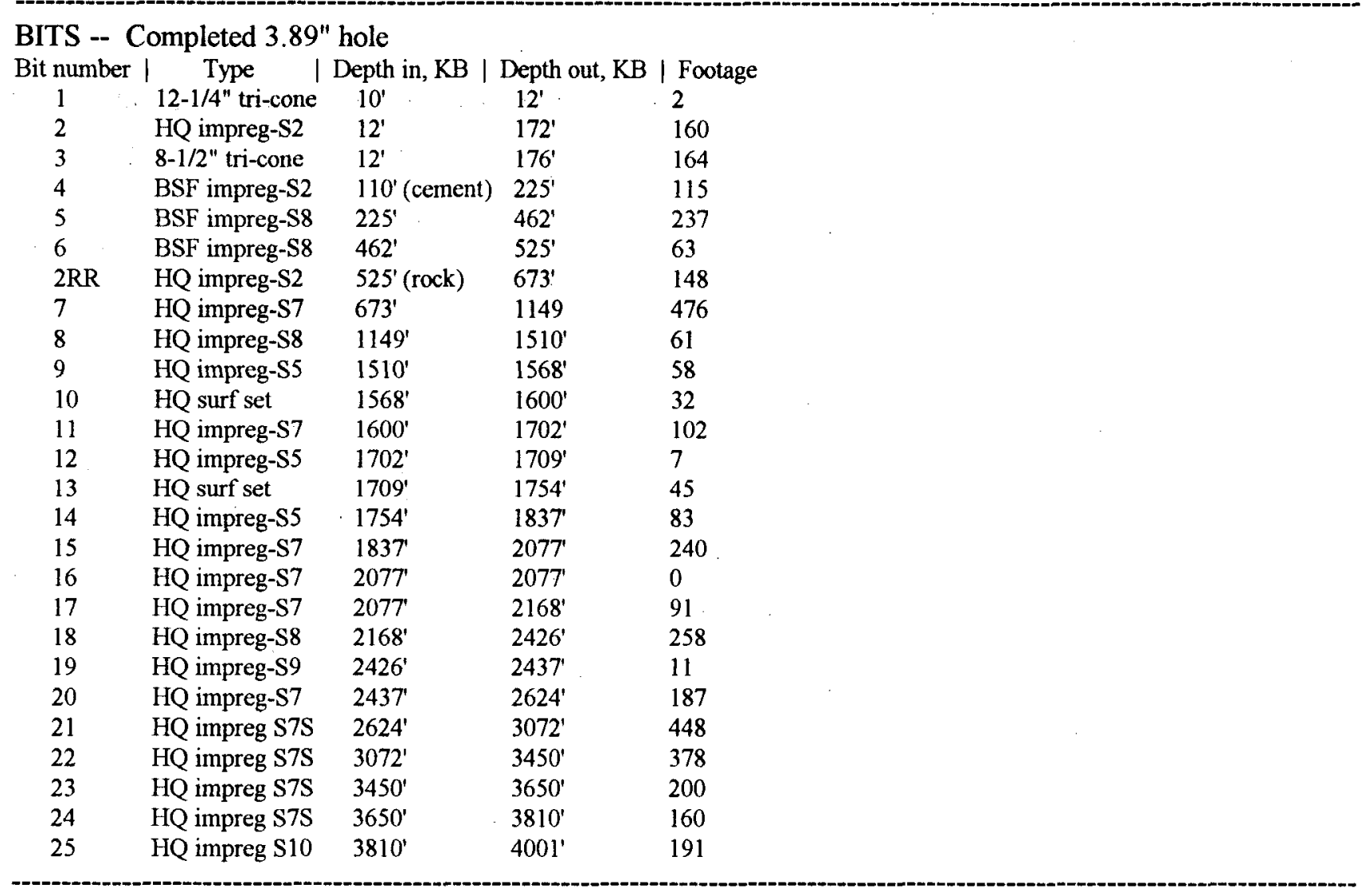

Drilling fluid $-\mathbf{n} / \mathbf{a}$

Lithology of core logged since yesterday: [Summary - detailed log available]

No new logs today

Summary of events last 24 hours:

Completed SNL temperature log to bottom with no obstruction. Rigged up for injection into slimhole. Injected $\sim 940 \mathrm{gpm}$ with 60 psi wellhead pressure, while taking downhole PTS data and surface measurements. Rigged up to RIH with packer to $1060^{\prime}$. Objective of packer test is to seal off wellbore below it from flow out of upper fractures and observe effect on temperature, then pump into zone below packer and compare permeability of that interval with complete wellbore. Packer sets and holds pressure, but we cannot retrieve the standing valve that seals the packer for inflation. Release packer pressure by rotating it, then POOH. Crossover between packer and drill pipe is too small at ID to pass standing valve overshot. Replace crossover sub and RIH with new packer. It sets successfully; rigging up for static log through packer.

Report by: John Finger 
DAILY DRILLING REPORT - 09/15/93

STEAMBOAT HILLS EXPLORATORY SLIMHOLE

Time of report - 0800

Well number - SNLG 87-29 | Location - SE 1/4, SE 1/4, Section 29, T18N, R20E, Washoe County, NV

Days since spud - $57 \mid$ Depth today - 400 ' | Hole advance last $24 \mathrm{hr}-0^{\prime} \mid$ Core recovered - $0^{\prime}$

Last casing - 4-1/2", $11.5 \mathrm{lb} / \mathrm{ft}$ @ 524'

BITS -- Completed 3.89" hole

Used: 1 ea 12-1/4" tricone; 1 ea 8-1/2" tricone; 3 ea 6-1/4" impregnated core bits; 2 ea HQ surface set bits; and 18 HQ impregnated bits. Bit life averaged over $250^{\prime}$ for the last six HQ bits, with an overall average of just under $200^{\prime}$ for the HQ impregnated bits.

Drilling fluid - $\mathrm{n} / \mathrm{a}$

Lithology of core logged since yesterday: [Summary - detailed log available]

No new logs today

Summary of events last 24 hours:

Ran pressure/temperature log through packer to TD. Waited 4 hours and repeated; temperatures below packer were identical, with slight wellbore heating above it. Rigged up to pump cold water through packer and did PT log through packer to TD; temperatures below $\sim 2100^{\prime}$ changed imperceptibly, with large wellbore cooling above that. POOH with packer and $\mathrm{RIH}$ to $2450^{\prime}$ with new packer, planning to repeat the previous test. Cannot get packer to hold pressure. $\mathrm{POOH}$ with that packer, lay it down, pick up other packer which has been refurbished from previous test, RIH and set it at $2450^{\prime}$. RIH with PT tool (had to remove spinner because it's too big to pass through packer valve seat) for static log.

Report by: John Finger 
DAILY DRILLING REPORT - 09/16/93

STEAMBOAT HILLS EXPLORATORY SLIMHOLE

Time of report - 0800

Well number - SNLG 87-29 | Location - SE 1/4, SE 1/4, Section 29, T18N, R20E, Washoe County, NV

Days since spud - 58 | Total depth - 4001'

Last casing - 4-1/2", $11.5 \mathrm{lb} / \mathrm{ft} @ 524^{\prime}$

BITS -- Completed 3.89" hole

Used: 1 ea 12-1/4" tricone; 1 ea 8-1/2" tricone; 3 ea 6-1/4" impregnated core bits; 2 ea HQ surface set bits; and 18 HQ impregnated bits. Bit life averaged over $250^{\prime}$ for the last six HQ bits, with an overall average of just under $200^{\prime}$ for the HQ impregnated bits.

Drilling fluid - $\mathbf{n} / \mathbf{a}$

Lithology of core logged since yesterday: [Summary - detailed log available]

Core from $3210^{\prime}$ to $4000^{\prime}$ continued in the same granodiorite previously described. There are many strongly to intensely altered zones interlayered with unaltered rock. Vugs range up to $10 \mathrm{~cm}$, with most fractures continuing to be near vertical $\left(75-90^{\circ}\right)$. Numerous fractures and vugs below $3500^{\prime}$ contain barite, usually indicative of temperatures over $350^{\circ} \mathrm{F}$, but the formation is not now that hot.

Summary of events last 24 hours:

Ran second static pressure/temperature log through packer at $2690^{\prime}$ to TD (6 hours after first static $\log$.) Temperature below packer had not changed from previous log. Rigged up to inject through packer. Injection rate was $260 \mathrm{gpm}$ at $110 \mathrm{psi}$ wellhead pressure, compared to $450 \mathrm{gpm} / 90 \mathrm{psi}$ with packer set at $1060^{\prime}$. Part of this difference is due to additional friction loss in the longer pipe and different fluid temperatures at injection, but it appears that permeability in the lower part of the hole is considerably less than that above. Attempted to run PT survey below packer, but logging tool could not get below $2700^{\prime}$ because of apparent bridge. POOH with logging tool and drillpipe. Pressurized wellhead and released to start flow for production test. Flowed well for 2 hours and RIH with Sandia PT memory tool. Continued flow for $1 / 2$ hour and then shut in for $4-1 / 2$ hours. POOH with memory tool; it had successfully taken data which can be compared with shut-in data from commercial loggers. RIH to TD with drillpipe for wiper trip and encountered obstruction at $2700^{\prime}$, where logging tool was stopped. $\mathrm{POOH}$ in $10^{\prime}$ joints, laying down pipe. Will release rig within next 24 hours.

This is the final Daily Drilling Report from the Steamboat Hills Exploratory Slimhole.

Report by: John Finger/Ron Jacobson 


\section{DISTRIBUTION}

David N. Anderson

Geothermal Resources Council

PO Box 1350

Davis, CA 95617

Jim Combs

Geo Hills Associates

27790 Edgerton Road

Los Altos Hills, CA 94022

Greg Taylor

Christensen Boyles Corporation

PO Box 30777

Salt Lake City, UT 84130

Alan Melchior

Far West Capital

921 Executive Park Drive, Suite B

Salt Lake City, UT 84117

Eric Call

SB Geo

PO Box 18087

Reno, NV 89511

Dave Harvey

PO Box 10263

Reno, NV 89510

Colin Goranson

1498 Aqua Vista Road

Richmond, CA 94805

Jim Lovekin

California Energy Co.

900 North Heritage, Bldg D

Ridgecrest, CA 93555

Marc Steffen

Cal-Pine Corporation

1160 North Dutton, Suite 200

Santa Rosa, CA 95401

Walter Haenggi

Magma Power Company

551 West Main Street, Suite 1

Brawley, CA 92227
Bureau of Land Management (2)

Attn: Michael Ferguson

Cheryl Seath

787 N. Main, Suite P

Bishop, CA 93514

R. C. Edmiston

Anadarko Petroleum Corporation

835 Piner Road, Suite A

Santa Rosa, CA 95403

Robert Deputy

ARCO Oil and Gas Co.

2300 W. Plano Parkway

Plano, TX 75075

Sue Goff

LANL, MS D-443

Los Alamos, NM 87545

Charles George

Halliburton Services

Drawer 1431

Duncan, OK 73536

Barry Harding

Ocean Drilling Program

Texas A\&M University

1000 Discovery Drive

College Station, TX 77840

George Cooper

Dept. of Materials Science \&

Mineral Engineering

University of California

Berkeley, CA 94720

Helene Knowlton

Smith International

16740 Hardy Street

Houston, TX 77205

Frank Monastero

US Navy - Geothermal Office

China Lake, CA 93555 
John Mastor (4)

Longyear Company

PO Box 1000

Dayton, NV 89403

B. J. Livesay

126 Countrywood Lane

Encinitas CA 92024

Daniel Lyster

Mono County Energy Mgmt.

HCR 79, PO Box 221

Mammoth Lakes, CA 93546

Desert Drilling Fluids (4)

Attn: Gene Polk

3316 Girard Blvd NE

Albuquerque NM 87107

Nic Nickels

Eastman Christensen

3636 Airway Drive

Santa Rosa, CA 95403

Steve Pye

Unocal Geothermal

PO Box 7600

Los Angeles, CA 90017

John Sass

USGS

2255 North Gemini Drive

Flagstaff, AZ 86001

Larry Larson

Nabors Loffland

515 West Greens Road, Suite 310

Houston, TX 77067

Tonto Drilling Services (2)

Attn: George McLaren

Larry Pisto

PO Box 25128

Salt Lake City, UT 84125

Tommy Warren

Amoco Production Center

PO Box 3385

Tulsa, OK 74102
G. S. Bodvarsson (4)

Earth Sciences Division

Lawrence Berkeley Lab

1 Cyclotron Road

Berkeley, CA 94720

US Department of Energy (3)

Geothermal Division

Attn: Ted Mock

Stan Calvert

Marshall Reed

Forrestal Bldg., CE-324

1000 Independence Ave. SW

Washington, DC 20585

Susan Hodgeson

Division of Oil and Gas

20th Floor, MS-20

$801 \mathrm{~K}$ Street

Sacramento, CA 95814-3530

Elizabeth Johnson

Div. of Oil and Gas - Geothermal

20th Floor, MS-21

$801 \mathrm{~K}$ Street

Sacramento, CA 95814-3530

Warren Bollmeier

PICHTR

2800 Woodlawn Dr, Suite 180

Honolulu, HI 96822

Dick Benoit

Oxbow Power Services, Inc

200 South Virginia St, Suite 450

Reno, NV 89501

George Darr

Geothermal Program Manager

Bonneville Power Administration

PO Box 3621

Portland, OR 97208-3621

Mohinder Gulati

UNOCAL Geothermal

PO Box 7600, Room M-36

Los Angeles, CA 90051 
Thomas C. Hinrichs

Magma Power Company

11770 Bernardo Plaza Ct, Suite 366

San Diego, CA 92128

S. K. Garg

S-Cubed

PO Box 1620

La Jolla, CA 92038-1620

Cal Strobel

Unocal Geothermal

PO Box 6854

Santa Rosa, CA 95403-1774

Tsvi Meidav

Trans-Pacific Geothermal Corp.

1901 Harrison St, Suite 1590

Oakland, CA 94612

Joel Renner

Manager, Renewable Energy Programs

Idaho Nat'l Engineering Lab.

PO Box 1625

Idaho Falls, ID 83415

Richard Thomas

Geothermal Officer

Calif. Div of Oil \& Gas

1416 Ninth St, Room 1310

Sacramento, CA 95814
MS 0899 Technical Library (7) 7144

MS 0100 Document Processing for DOE/OSTI (10)

7613-2

MS 0619 Tech. Publications 7151

MS 9018 Central Tech. Files 7144

MS 0724 D. L. Hartley $\quad 6000$

MS 0701 R. W. Lynch $\quad 6100$

MS 1033 J. C. Dunn (10) 6111

MS 1033 J. T. Finger (20) $\quad 6111$

MS 1033 R. D. Jacobson 6111

MS 1033 D. A. Glowka 6111

MS 1033 P. Gronewald 6111

MS 1033 P. C. Lysne 6111

MS 1033 R. D. Meyer 6111

MS 1033 D. M. Schafer $\quad 6111$

MS 0419 K. G. Pierce 4112

MS 0827 C. E. Hickox 1511

MS 0827 R. R. Eaton 1511 